\title{
Articles
}

\section{Falling Off the Vine: Legal Fictions and the Doctrine of Substituted Judgment}

\section{Louise Harmon $\dagger$}

The legal fiction used to be a hot topic on the jurisprudential agenda. It was written and talked about passionately by those who wrote and talked about such things in the nineteenth and early twentieth centuries. Then interest in the subject withered and died, and virtually fell off the vine.

Why would anyone want to write, or read for that matter, an article about a formerly hot topic? For historical insight perhaps. Subjects that were once intensely debated can reveal the circumstances and concerns of those who went before us; they promote an understanding of an earlier time. But even the historical purist needs to feel that a formerly hot topic has some bearing on how we lead our lives today-or that the insights we gain from its study might matter in the future somehow.

I would like to revive the debate on the legal fiction. It is a subject worthy of enduring concern. I came to this conclusion from my study of the history of the doctrine of substituted judgment, which has its origins in the early nineteenth-century law of lunacy. Lord Eldon crafted the legal fiction of "doing that which it is probable the lunatic himself would have done," permitting equity courts to make gifts of the lunatic's surplus income to relatives for

$\dagger$ Associate Professor of Law, Touro College Jacob D. Fuchsberg Law Center. I am grateful to the following people for their invaluable assistance in the preparation of this Article: Robin A. Bielski and Wendi K. Waldman for their help with the research; Charles B. Wheeler for his help with the words; and Daniel P. Jordan Jr. for his help with the children. 
whom the lunatic owed no duty of support. About twenty years ago the legal fiction was borrowed from the law of lunacy into the law of informed consent. There it has been used by courts to remove organs from the body of the incompetent, to sterilize him, to force medication on him, to let him wither and die, and virtually fall off the vine.

Here is how I proceed. In Part I, I sketch the outlines of the historical debate on the legal fiction. I ask whether legal fictions are dangerous, and if so why. In Part II, I present the history of the doctrine of substituted judgment, from its nineteenth-century origins to the recent Supreme Court decision on Nancy Cruzan's life and death. In Part III, I argue that substituted judgment is a dangerous legal fiction, and that its history reveals why. It is an essay about word seduction and wordless victims, about the hidden exercise of power and the infirmities of the human mind.

\section{The Historical Debate on the Legal Fiction}

What is a legal fiction? None of the participants in the historical debate could agree. The problem was one of scope: what should be included in the definition. There was no dispute over what came to be called the "procedural" legal fiction; it provided the narrow and classic definition. A procedural legal fiction was a false allegation of fact; it could not be challenged and was usually employed to enlarge jurisdiction. ${ }^{1}$ Procedural legal fictions could also be used to extend substantive remedies. ${ }^{2}$ The pretense was of a fact that would, if true, have led to a desired result under the existing rules of law.

Many of the participants in the historical debate took a much broader view of the legal fiction, however. Maine, for example, defined a legal fiction as "any assumption which conceals, or affects to conceal, the fact that a rule of law has undergone alteration, its letter remaining unchanged, its operation being modified."3 Fuller defined a legal fiction as "either (1) a statement propounded with a complete or partial consciousness of its falsity, or (2) a false statement recognized as having utility." 4 He included such devices as constructive delivery, ${ }^{5}$ implied provisions in contracts, ${ }^{6}$ and different kinds of legal presump-

1. See J. BAKER, AN INTRODUCTION TO ENGLISH LEGAL HISTORY 230-31 (3d ed. 1990). In the 15th and 16th centuries, there are several examples of English courts using legal fictions to enlarge their jurisdiction. See id. at 50-51 (discussing bill of Middlesex and writ of latitat); id. at 57-59 (allegation of quominus); id. at 141,143 (admiralty jurisdiction).

2. See id. at 384 (false allegation of deceit in assumpsit); id. at 449-50 (allegation of loss and finding in trover); $i d$. at 341-42 (false allegation of lease and ouster in ejectment); id. at 319-20 (collusive common recovery).

3. Maine, Ancient Law, in THE PROBLEMS OF JURISPRUDENCE 371 (L. Fuller ed. 1946) (chapter reprints first half of H. MAINE, ANCIENT LAW (1861)). In referring to the fictions of Roman law, and to some of the older, jurisdictional common law fictions, Maine wrote, "The fact is in both cases that the law has been wholly changed; the fiction is that it remains what it always was." Id. at 370 (emphasis in original).

4. L. FULLER, LEGAL FICTIONS 9 (1967).

5. See id. at 15 . 
tions. ${ }^{7}$ Pound was the most expansive of all, including in his definition of legal fiction interpretation, equity, and natural 1 law. ${ }^{8}$ There was no agreed-upon definition.

There are several responses to definitional quicksand. One is to refuse to build at all, but then nothing interesting goes into the air. Another is to try to lay a foundation by providing a new definition, but the earlier participants in the debate would remain stubbornly committed to their own definitions. It is difficult enough to reform the living, impossible the dead. My own response is to take a deep breath and start the project anyway. Quicksand is better than no sand at all. We will just have to put up with some shifting.

Most of the participants in the historical debate expressed varying degrees of toleration for the legal fiction. I use the word "toleration," rather than a heartier sign of approbation, since none of the participants gave the legal fiction his unqualified support. There may have been recognition of its utility, but certainly no thunderous applause. Indeed, even those who thought the legal fiction had its time and place seemed somewhat embarrassed by it.

Jeremy Bentham's hostility toward the legal fiction went far beyond the blushing and stammerings of embarrassment, however. While he never formally declared war or gave the subject a separate subheading, ${ }^{9}$ Bentham sniped violently and erratically at fictional devices in general. These skirmishes usually took place in the dense undergrowth of a Benthamite footnote. In particular, he despised the fiction of the social contract as the basis for political obligation. In describing conversations with lawyers who believed in this "original contract," Bentham used the metaphor of drug abuse:

This drug of theirs they administered to me to calm my scruples. But my unpractised stomach revolted against their opiate. I bid them open to me that page of history in which the solemnization of this important contract was recorded. They shrunk from his challenge; nor could they, when thus pressed, do otherwise than our Author [Blackstone] has done, confess the whole to be a fiction. ${ }^{10}$

In another work, after excoriating lawyers who believed in the social contract, Bentham again characterized fictions as an opiate: "They [lawyers] feed upon untruth, as the Turks do upon opium, at first from choice and with their eyes

6. See id. at 4,8 .

7. See id. at $40-48$.

8. See R. POUND, INTERPRETATIONS OF LEGAL HISTORY 131 (1923).

9. Bentham came closest to giving the legal fiction top billing in J. BENTHAM, Scotch Reform, in 5 THE WORKS OF JEREMY BENTHAM 13 (J. Bowring ed. 1843).

10. J. BENTHAM, A Fragment on Government, in 1 THE WORKS OF JEREMY BENTHAM 268-69 note h (J. Bowring ed. 1843). 
open, afterwards by habit, till at length they lose all shame, avow it for what it is, and swallow it with greediness, not bearing to be without it."11

But Bentham did not confine his attack on fictional devices to the social contract. He was also a harsh critic of the common law. It was plagued with "[f]iction, tautology, technicality, circuity, irregularity, inconsistency . . . . But above all, the pestilential breath of Fiction poisons the sense of every instrument it comes near."12 Here Bentham used the metaphor of disease: "[I]n English law, fiction is a syphilis, which runs in every vein, and carries into every part of the system the principle of rottenness." 13

Bentham's rantings about the rottenness of the legal fiction were thus symptomatic of his more general disgust with the common law. He loathed the common law for its failure to be accessible to the people who were bound by it. Bentham's antidote for this inaccessibility was codification. ${ }^{14} \mathrm{By}$ distilling the common law into a comprehensible, internally consistent code, Bentham hoped to shatter the monopoly that lawyers held on the language of the law. ${ }^{15}$ The legal fiction just happened to be the most pernicious weed growing in the sinister garden of the common law, and Bentham had it slated first for extirpation.

Bentham had a more specific ax to grind about the legal fiction, however. For Bentham, the legal fiction was a subterfuge for legislation. He defined a fiction of law as a "wilful falsehood, having for its object the stealing legislative power, by and for hands, which could not, or durst not, openly claim it,- - and, but for the delusion thus produced, could not exercise it." ${ }^{16}$ Bentham believed that there was a partnership between the monarch and the judiciary, and the purpose of that partnership was to steal power from Parliament. He referred to judges as "removable creatures" who were permitted to exercise the

11. J. BENTHAM, A Comment on the Commentaries, in A COMMENT ON THE COMMENTARIES AND A FRAGMENT ON GOVERNMENT 59 (1977).

12. J. BENTHAM, supra note 10 , at 235 note $s$.

13. J. BENTHAM, Elements of Packing as Applied to Juries, in 5 THE WORKS OF JEREMY BENTHAM, supra note 10, at 92 (emphasis in original).

14. See generally Comment, Jeremy Bentham's Codification Proposals and Some Remarks on Their Place in History, 22 BUFFALO L. REV. 239 (1972). The word "codification" was introduced into the English language by Bentham. See J. BAKER, supra note 1, at 249 n.108.

15. See J. BENTHAM, supra note 10 , at 235 note s. Bentham wrote in favor of a 1730 statute that required legal proceedings to be carried out in English and not "Law-Latin." Blackstone had been critical of the legislation; Bentham believed that the

fault, then, of the Legislature is their not having done enough. His [Blackstone's] quarrel with them is for having done any thing at all. In doing what they did, they set up a light, which, obscured by many remaining clouds, is still but too apt to prove an ignis fatuus: our Author, instead of calling for those clouds to be removed, deprecates all light, and pleads for total darkness.

Id. at 235 (emphasis in original).

16. J. BENTHAM, Preface For The Second Edition to A COMMENT ON THE COMMENTARIES AND A FRAGMENT ON GOVERMMENT, supra note 11, at 509. A period of 47 years elapsed between the first and second editions of A Fragment on Government. The lengthy second Preface was written by Bentham in 1822 , but it did not appear in a publication until 1838 when the first volume of the Bowring edition came out. See id. at $\mathrm{xxxii-xxxiii.}$ 
power of their office at the King's sufferance. ${ }^{17}$ These removable creatures were "called the court, for the purpose of letting in the servants to a share of the worship paid to the master."18 Under the guise of legal fictions, judges determined what morality, truth, and law should be. ${ }^{19}$ Bentham claimed that this usurpation of legislative function was prompted by greed. Legal fictions were "cover[s] for rascality"; their authors profited from their use. ${ }^{20}$ By legislating surreptitiously, judges were pulling the wool over the eyes of the public, and Bentham decried their veneration by the "deluded multitudes."21

Bentham was at one end of the spectrum in regard to the legal fiction. Not surprisingly, Sir William Blackstone was at the other. Blackstone came to the defense of the legal fiction in several passages of the Commentaries. ${ }^{22}$ One of his arguments was based on historical precedent. He made this argument during a discussion of a legal fiction that assumed certain contracts had been made at the Royal Exchange in London, when in fact the promises had been exchanged at sea. ${ }^{23}$ The fiction robbed the Court of the Lord High Admiral of jurisdiction, causing a certain "civilian" to exclaim against it "loudly, as inequitable and absurd." ${ }^{24}$ Blackstone had little patience for such exclamations: "[T] hat learned civilian himself seems to have forgotten how much such fictions are adopted and encouraged in the Roman law .....25

In the same breath, Blackstone tried to defend this legal fiction by minimizing its effect: "But our lawyers justify this fiction, by alleging as before, that the locality of such contracts is not at all essential to the merits of them . . . ."26 This is an attitude characteristic of a formalist. It assumes that
17. Id. at 510 .
18. $I d$. (emphasis in original).
19. Id. at 511 .
20. Id.
21. Id.

In another work, Bentham accused judges of using legal fictions as "instruments of their power": Falsehood-corrupt and wilful falsehood-mendacity, in a word-the common instrument of all wrong-was, in the instance of all those judicatories (as any man may see, even in Blackstone,) among the notorious foundations or instruments of their power: and, in every one of them, from the beginning of each cause to the end, sometimes by the lips or the hand, always under the eyes of the judge, matter of constant and universal practice. Not one of them, in which it is-not merely allowed of, but encouraged; and not only encouraged, but forced, inexorably forced. Without so much as an attempt at argument, in the very teeth of common sense, falsehood, the irreconcilable enemy of justice-falsehood, under the name of fiction-is passed off by them upon the deluded people-passed off as the true friend and necessary instrument of justice!

J. BENTHAM, supra note 13, at 92 (emphasis in original).

In another work, Bentham defined a legal fiction as a "wilful falsehood, uttered by a judge, for the purpose of giving to injustice the colour of justice." J. BENTHAM, supra note 9, at 13.

22. W. BLACKSTONE, COMMENTARIES ON THE LAWS OF ENGLAND (1768).

23. The common law courts watched the Court of the Lord High Admiral with "jealousy and suspicion." J. BAKER, supra note 1, at 142. The universal law of the sea was itself worthy of suspicion since it was "tainted with Romanism." Id.

24. 3 W. BLACKSTONE, COMMENTARIES *107. The "civilian" that Blackstone referred to was probably one of the judges of the admiralty who remained faithful to the civil law.

25. Id.

26. Id. 
the contents of a contract, or the "merits," exist in a vacuum-sealed box, impervious to the influence of judicial interpretation. But such an attitude is inconsistent with the purpose of the legal fiction that Blackstone was defending. Pretending that contracts were formed in a location where they were not deprived one court of jurisdiction and gave it to another. Buried beneath this effort to change jurisdiction was an acknowledgement that it mattered which court settled the dispute. If it did not matter, then there would have been no need to invent the legal fiction.

Blackstone was not inclined to make such an acknowledgement, however, at least not in his discussion of admiralty jurisdiction. It was just this sort of formalism and disingenuous reasoning that led Bentham to make the following accusation:

If there be one purpose for which a book of Institutes is wanted more than another, it is to draw aside that curtain of mystery which fiction and formality have spread so extensively over Law. Our Author [Blackstone] thinks he does his part when he embroiders it with flowers. Law shews itself in a mask. This mask our Author instead of pulling off has varnished. ${ }^{27}$

Of course, Bentham was probably right. Blackstone's project in the Commentaries did have more to do with embroidering flowers and varnishing masks than it had to do with drawing aside the curtain of mystery from the law. However, Bentham's indictment against Blackstone, at least with respect to the legal fiction, was somewhat unfair. Blackstone was more honest than many writers about the utility of the legal fiction. In an earlier section of the Commentaries, Blackstone described the notorious fictional trespass "vi et armis" that conferred jurisdiction over certain personal actions on the civil branch of the King's Bench. ${ }^{28}$ Only certain wrongs were considered suitable for the attention of the King's justices, among them a trespass committed vi et armis, "with force and arms." The defendant would be charged with a fictional trespass vi et armis, and under this pretense of force, the plaintiff was then free to proceed against him for almost any kind of wrong. ${ }^{29}$ Of such artifice, Blackstone remarked:

And these fictions of law, though at first they may startle the student, he will find upon further consideration to be highly beneficial and useful: especially as this maxim is ever invariably observed, that no fiction shall extend to work an injury; its proper operation being to

\footnotetext{
27. J. BENTHAM, supra note 11 , at 124 .

28. 3 W. BLACKSTONE, COMMENTARIES *43.

29. See J. BAKER supra note 1, at 72-73.
} 
prevent a mischief, or remedy an inconvenience, that might result from the general rule of law. ${ }^{30}$

Blackstone did not mince words in this passage: legal fictions could be "highly beneficial and useful." Nor was he reticent about why a legal fiction might be needed: he was worried about how a particular case might turn out. If the "general rule of law" were applied, without the assistance of a legal fiction, a "mischief" or an "inconvenience" might result. Blackstone also insisted that the use of a legal fiction be tempered by the maxim, "No fiction shall extend to work an injury." Once again, his concern was consequential: the device must not be employed to bring about an undesirable result.

In this passage, however, Blackstone demonstrated little insight into the conservative function of the legal fiction. After all, another way to avoid an undesirable result from the application of a general rule of law is to change the general rule of law. Blackstone failed to mention that the use of a legal fiction would render such a change unnecessary. The desirable result could be reached, and the rule would remain the same; the piece could be eaten without jeopardizing the cake. Blackstone remained silent in this passage about the flip side of the legal fiction. He was quite candid about its ability to achieve a desirable result, but did not allude to its ability to rescue the general rule.

In another passage in the Commentaries, however, Blackstone did allude to the ability of the legal fiction to maintain the doctrinal status quo. He also came close to criticizing the legal fiction. After describing a particularly contorted pretense designed to avoid an onerous land statute, Blackstone remarked:

To such awkward shifts, such subtle refinements, and such strange reasoning, were our ancestors obliged to have recourse in order to get the better of that stubborn statute de donis. The design, for which these contrivances were set on foot, was certainly laudable; the unrivetting the fetters of estates-tail, which were attended with a legion of mischiefs to the commonwealth: but, while we applaud the end, we cannot but admire the means. ${ }^{31}$

In this passage, Blackstone implied that the common law had somehow finished with the legal fiction. His generation of lawyers did not have to resort to the devices of their "ancestors." But later in the Commentaries Blackstone cautioned that they should put up with the "intricacy of our legal process" created by these "arbitrary fictions and expedients." 32 The legal fiction was "one of those troublesome, but not dangerous, evils which have their root in

30. 3 W. BLACKSTONE, COMMENTARIES *43.

31. $2 \mathrm{id}$. at 360 .

32. 3 id. at 267. 
the frame of our constitution, and which therefore can never be cured, without hazarding everything that is dear to us." 33

Blackstone went on to cite the example of feudal forms of action that caused delay and presented "a hundred other formidable entrenchments" to the swift exchange of property. ${ }^{34}$ By leaving these forms of action intact, no matter how cumbersome they had become, the judges who invented legal fictions to circumvent them "wisely avoided soliciting any great legislative revolution in the old establishment forms." 35 Changing rules by fiat may have been appropriate for "absolute governments . . . a single legislator or an enterprising sovereign," but not for a government run by "popular assemblies."36 Blackstone's generation of lawyers should applaud the judges for hanging on to the feudal forms of action, for letting them "languish in obscurity and oblivion." ${ }^{37}$ These "minute contrivances" designed to achieve desirable and speedy results had been refined over the years and had become "sufficiently known and understood." 38 Thus the only drawback to legal fictions was their tendency to confuse and annoy; they were the gnats of the common law.

In these passages, Blackstone introduced a theme that was picked up by several subsequent writers. ${ }^{39}$ The legal fiction belonged to the past. To make his point, Blackstone launched into one of his rare metaphors:

We inherit an old Gothic castle, erected in the days of chivalry, but fitted up for a modern inhabitant. The moated ramparts, the embattled towers, and the trophied halls, are magnificent and venerable, but useless. The inferior apartments, now converted into rooms of convenience, are chearful and commodious, though their approaches are winding and difficult. ${ }^{40}$

\section{Id.}

34.

When therefore, by the gradual influence of foreign trade and domestic tranquility, the spirit of our military tenures began to decay, and at length the whole structure was removed, the judges quickly perceived that the forms and delays of the old feudal actions, (guarded with their several outworks of effoins, vouchers, aid-prayers, and a hundred other formidable entrenchments) were ill suited to that more simple and commercial mode of property which succeeded the former, and required a more speedy decision of right, to facilitate exchange and alienation.

Id. at 267-68.

35. Id. at 268.

36. Id. at 267 .

37. Id. at 268 .

38. Id.

39. Even Bentham had grudgingly admitted that the fiction of the social contract may have been useful during an earlier period in the history of the common law:

With respect to this, and other fictions, there was once a time, perhaps, when they had their use. With instruments of this temper, I will not deny but that some political work may have been done, and that useful work, which, under the then circumstances of things, could hardly have been done with any other. But the season of Fiction is now over ....

J. BENTHAM, supra note 10, at 268-69 (emphasis in original).

40. 3 W. BLACKSTONE, COMMENTARIES $* 268$. 
The legal fiction was just one of those winding and difficult approaches, a vestigial architectural feature from days gone by. Or as Blackstone so neatly put it, a "troublesome, but not dangerous" evil.41

Bentham and Blackstone represented two diametrically opposed positions. Bentham regarded legal fictions as evil, as usurpers of legislative function. Blackstone regarded them as benign, as harmless remnants from an earlier period of history. John Austin and Sir Henry Maine were two prominent nineteenth-century thinkers who also wrote about the legal fiction, carrying on the historical debate that Bentham and Blackstone had initiated.

While Austin owed a hefty intellectual debt to Bentham, ${ }^{42}$ he did not side with him on the legal fiction. Austin did not agree with Bentham that judges intended to "delude" the public with legal fictions. In discussing the legal fiction in Roman law, Austin remarked, "It is ridiculous to suppose that such fictions could deceive, or were intended to deceive: or that the authors of such innovations had the purpose of introducing them covertly."43 Neither did Austin share Bentham's belief that judges were motivated by a desire for power in their use of the legal fiction. Rather, Austin believed that the use of the legal fiction was motivated by a nostalgia for rules that had outlived their utility. In this respect, Austin was sensitive to the role that legal fictions played in conserving the rules of law. Again, in his discussion of Roman legal fictions, Austin provided two reasons for their use: "1st, a respect for the law which they virtually changed: 2ndly, A wish to conciliate the lovers of things ancient." 44 Regarding the fictions of English law, such as the fiction that husband and wife are one person, Austin attributed their origin to "ignorant attempts on the part of judges or lawyers to account for laws originating in customs belonging to an ancient form of society, but repudiated by modern sentiments."45

Maine was more or less aligned with Blackstone. Almost a century later, Maine echoed Blackstone's theme that legal fictions belonged to the past. But Maine's claim was more ambitious. He ascribed to an evolutionary theory of

41. Id, at 267 .

42. Bentham and Austin were both utilitarians and legal positivists. Austin was offered the chair in jurisprudence at the University of London on its founding in 1826 by the Benthamites. Austin's The Province of Jurisprudence Determined, published in 1832, is an expanded version of the first series of lectures that he gave at the University of London. Like Bentham, Austin believed that legal study was not concerned with any ideal law, but only with existing, man-made law. Furthermore, Austin claimed that no reference to morality entered into the definition of law. Austin is most famous for his command theory of law. A rule is a species of command that obliges one to do or forbear from doing something because of fear of sanction by the sovereign. For a critique of Austin's analysis of law as the sovereign's coercive orders, see H.L.A. HART, THE CONCEPT OF LAW 18-25 (1961). Hart nonetheless upholds the positivist tradition of Bentham and Austin by denying any necessary connection between the concepts of law and morality.

43. J. AUSTIN, LECTURE ON JURISPRUDENCE OR THE PHILOSOPHY OF POSITIVE LAW 308 (1874)

44. $I d$.

45. Id. 
legal history. ${ }^{46}$ According to Maine's theory, the legal system of every progressive society moved from primitive law through a period of customary law, and then on to a period of codification. In a progressive society, ${ }^{47}$ social necessities and opinion were always ahead of the law. Even if the gulf between them closed temporarily, it had "a perpetual tendency to reopen. Law is stable; the societies we are speaking of are progressive. The greater or less happiness of a people depends on the degree of promptitude with which the gulf is narrowed."48

Maine isolated three instrumentalities by which the law could be brought into harmony with the changing attitudes of a progressive society. Listing them in "historical order," the three instrumentalities were: 1) the legal fiction; 2) equity; and 3) legislation..$^{49}$ Legal fictions were congenial to the early stages of social progress because they satisfied the desire for improvement, but did "not offend the superstitious disrelish for change which is always present. At a particular stage of social progress they are invaluable expedients for overcoming the rigidity of the law." 50

Maine had an advantage over Blackstone because he had an opportunity to defend the legal fiction against Bentham's guerilla warfare. After praising the fiction of adoption, Maine wrote: "We must, therefore, not suffer ourselves to be affected by the ridicule which Bentham pours on legal fictions wherever he meets them. To revile them as merely fraudulent is to betray ignorance of their peculiar office in the historical development of law." 51

Maine did not share Blackstone's nonchalance about the legal fictions that had survived, however. While Maine agreed with Blackstone that they were anachronisms, he would never have characterized them as empty towers or harmless moats encircling the Gothic castle of the common law. Instead, Maine claimed that the surviving legal fictions exerted a "powerful influence on English jurisprudence which could not be discarded without a severe shock to the ideas, and considerable change in the language of English practitioners." At least in this respect, Maine and Bentham saw eye to eye: they both took the legal fiction seriously.

46. See Maine, supra note 3, at 357.

47. Maine had rather firm ideas about what constituted a "progressive" society. Progressive societies were to be distinguished from "stationary" societies. Stationary societies were those in which development had ceased. Examples included "primitive" cultures, "Brahminical India" which seemed stuck at "the stage at which a rule of law is not yet discriminated from a rule of religion," and China, whose growth was stunted "because the civil laws are co-extensive with all ideas of which the race is capable." Id. at 369-70. Maine thought that stationary societies were the rule, progressive societies the exception.

48. Id.

49. Of the three instrumentalities, Maine claimed that "their historical order is that in which I have placed them." Id. at 370 . While two of them might operate simultaneously in a given society, and some legal systems might have escaped the influence of one of them, Maine knew "of no instance in which the order of their appearance has been changed or inverted." Id.

50. Id. at 371.

51. Id.

52. Id. 
Nevertheless, Maine and Bentham had different reasons for doing so. Bentham saw the legal fiction as a tool for the usurpation of legislative function. Because of his evolutionary theory of legal history, Maine did not regard the two "instrumentalities" as being in conflict; the legal fiction merely preceded legislation in the natural course of events. Rather, Maine's complaints were those of a taxonomist. Legal fictions were "rude devices" that made the law difficult to understand, and, above all, "harder to arrange in harmonious order." 53 In the same vein, Maine continued: "[L]egal fictions are the greatest of obstacles to symmetrical classification. The rule of law remains sticking in the system, but it is a mere shell. It has long been undermined, and a new rule hides itself under its cover." 54

Maine and Bentham shared a desire to make the law accessible, but they differed as to who should have access to it. Bentham wanted the layman to understand the law. His effort to reorganize and codify the law was designed to demystify it, to break the monopoly that lawyers held on the language of the law. Maine had no such plan in mind. His desire for a symmetrical system of classification was motivated by a concern for the education of the "English practitioner." For Maine, the legal fiction was offensive because it made the law murky for the lawyer, not because it made the law murky for the layman. Bentham, on the other hand, would have liked to dismantle the distinction between lawyer and layman altogether. And it was to that end that he poured his poisonous prose upon the legal fiction.

The legal fiction did not remain a hot topic on the jurisprudential agenda throughout the nineteenth century. For some reason, interest cooled down until the 1920's when Roscoe Pound, John Chipman Gray, and Lon Fuller rekindled the dormant fires that Bentham had once so vigorously poked and prodded. Pound perhaps took the broadest view of what the legal fiction consisted of, including such bulwarks of Anglo-American jurisprudence as interpretation, equity, and natural law. .5 In his earlier work, Pound shared Bentham's disdain for the legal fiction. In a 1907 article, ${ }^{56}$ Pound, borrowing a phrase from Austin, classified the legal fiction as a type of "spurious interpretation." Spurious interpretation was to be distinguished from "genuine interpretation." The purpose of genuine interpretation was noble: it was "to discover the rule which the law-maker intended to establish; to discover the intention with which the law-maker made the rule, or the sense which he attached to the words wherein the rule is expressed." 57 The purpose of spurious interpretation was ignoble: it was "to make, unmake, or remake, and not merely to discover . . . . It is essentially a legislative, not a judicial process, made necessary in formative

53. Id.

54. Id.

55. See R. Pound, supra note 8, at 130-34.

56. Pound, Spurious Interpretation, 7 COLUM. L. REV. 379, 381 (1907).

57. Id. 
periods by the paucity of principles, feebleness of legislation, and rigidity of rules characteristic of archaic law."58

In 1907, Pound had nothing good to say about spurious interpretation. His examples included implications in the law, phrases such as "constructive fraud," and of course, the legal fiction. These kinds of devices may have had a role to play in an earlier period of the common law's development, but in the "age of legislation," they were anachronisms. ${ }^{59}$ Spurious interpretation also had a detrimental effect when it was applied in the modern state. Pound isolated three negative features of spurious interpretation: it brought law into disrepute; it subjected courts to political pressure; and it introduced a "personal element" into judicial decisionmaking. ${ }^{60}$

Pound's attitude changed, however. In the Interpretations of Legal History, published in 1923, Pound no longer relegated the legal fiction to the annals of history. ${ }^{61}$ Furthermore, he abandoned his disdain for the legal fiction. For the pretense of corporate citizenship, for example, Pound had nothing but praise: the legal fiction was "creative law-making, inventive activity." 62 As for procedural fictions, and the even "bolder and more general fictions of interpretation, equity and natural law," 63 Pound had come to regard them as "creative devices of far-reaching effect which did not evolve spontaneously but were deliberately made by known men to meet definite demands in concrete cases." ${ }^{\prime 4}$ Ironically, given his earlier sympathy for Bentham's position, Pound turned out to be one of the legal fiction's most ardent admirers.

Gray was more cautious about the legal fiction. He borrowed a classification scheme from Ihering that broke legal fictions down into "historic," or procedural, fictions and "dogmatic" fictions. ${ }^{65}$ As their label would suggest, historic fictions belonged to an earlier period of the common law. Here Gray expressly aligned himself with Maine, claiming that "fictions of the historical kind are almost a necessity of the Law at a certain stage of human development." ${ }^{166} \mathrm{He}$ also implicitly aligned himself with Blackstone through his use of an architectural metaphor that sounded a great deal like the "Gothic Castle." Historic fictions were like "scaffolding, - useful, almost necessary, in construction, - but, after the building is erected, serving only to obscure it." ${ }^{\prime 67}$

58. Id. at 382 .

59. Id. at 383 .

60. Id. at 384 .

61. Of the legal fiction that an authoritative text means what "it palpably did not mean," Pound wrote, "In every stage of legal development this sort of interpretation has been one of the main resources of courts and jurists." R. POUND, supra note 8 , at 131.

62. Id. at 130 .

63. Id. at 131 .

64. Id.

65. See J. GRAY, THE NATURE AND SOURCES OF THE LAW 30-37 (1921).

66. Id. at 35.

67. Id. 
Yet Gray was fairly critical of historic fictions. He understood their ability to change the law while still maintaining the doctrinal status quo, referring to them as "devices for adding new law to old without changing the form of the old law." "68 But his chief objection to historic fictions was the same as Maine's: they interfered with the symmetry of classification. Gray also made a distinction between the use of historic fictions in Roman law and in the common law: " [] $\mathrm{t}$ is characteristic of the two peoples that the use of fictions in England was bolder and, if one may say so, more brutal in England than it was in Rome." 69

How did Gray distinguish the English from the Roman historic legal fiction? What made it "bolder" and "more brutal"? The Roman historic fiction was expressed in terms of "as if." Roman law, for example, recognized the fiction that a foreigner would be considered a citizen for purposes of obtaining jurisdiction over him. There was no direct allegation that the foreigner was a citizen, however. Rather, the praetor would instruct the trial judge in the following way: "If, in case Aulus had been a Roman citizen, such a judgment ought to have been rendered, then render such a judgment." would expressly admit the falsity of the assumption that conferred the jurisdiction. Thus the Roman historic fiction was festooned with a banner announcing the presence of artifice underneath. This was not true of the common law historic fiction. Employing a similar device, the plaintiff in England would directly allege that the foreigner was a citizen, which "was false, but the court did not allow the defendant to contradict it."71 There was no language of "as if" to warn of the allegation's falsity.

Gray was less critical of "dogmatic" legal fictions. Unlike historic fictions, dogmatic fictions were not used to add new law to old, but "to arrange recognized and established doctrines under the most convenient forms." the attribution of will to abnormal human beings to exemplify dogmatic fictions. He defined a man's legal rights as those which society will enforce on the motion of someone authorized to put those rights in motion. With normal human beings, the only person so authorized is the human being himself. With abnormal human beings, society authorizes someone else to put those rights in motion. It is a dogmatic fiction to say that "the will of some one else exercised on his behalf, is the will of the possessor of the right." out of convenience so that we can group together the rights given to both classes of human beings. According to Gray, attributing will to abnormal human beings merely helps to classify their legal rights under the correct subheading.

\footnotetext{
68. $I d$. at 30 .

69. Id. at 31-32.

70. Id. at 32 .

71. Id.

72. Id. at 36 .

73. Id. at 37-38.
} 
The dogmatic fiction is an aid to the taxonomist, a way of maintaining symmetry.

Gray found dogmatic fictions like this one "compatible with the most refined and most highly developed systems of Law. Instead of being blameworthy, they are to be praised when skillfully and wisely used." admiration was tempered by words of admonition. Dogmatic fictions, "though handy," were "dangerous tools": 75 "They should never be used, as the historic fictions were used, to change the Law, but only for the purpose of classifying established rules, and one should always be ready to recognize that the fictions are fictions, and be able to state the real doctrine for which they stand."76

Gray did not reveal why he thought dogmatic fictions were "dangerous tools." He never explained why they should not be used to covertly change the law. He was similarly opaque about his preference for the guileless Roman historic fiction. What was more "brutal" about a fiction that was unadorned with the language of "as if"? Gray's warnings were couched in terms of danger and brutality; they suggested the presence of evil. But on this subject, Gray had little more to say, and the nature of that evil remained a mystery. ${ }^{77}$

Of those who wrote about the legal fiction in the twentieth century, it was Lon Fuller who had the most to say. No writer before or since has given the topic such a thorough and sustained treatment. Fuller even wrote a book entitled Legal Fictions, ${ }^{78}$ a slim volume perhaps, but still one with chapters, footnotes, and other indicia of serious intent.

Fuller made two distinctions that narrowed the subject matter of his discussion: the distinction between a fiction and a lie and the distinction between a fiction and an erroneous conclusion. A fiction was distinguished from a lie by the fact that it was not meant to deceive. The user of a legal fiction did not intend to produce belief in those who heard or read it. Neither did the user of a legal fiction himself believe the false statement. The legal fiction was distinguished from an erroneous conclusion by the fact that it was used with knowledge of its falsity. As Fuller put it, the author of the legal fiction "either positively disbelieves it or is partially conscious of its untruth or inadequacy.".79

Fuller was the first writer on the subject to treat the legal fiction as a linguistic phenomenon, characterizing such a device as a "disease or affectation of language. ${ }^{180} \mathrm{He}$ pointed out that the legal fiction is evidence of the "myste-

74. Id. at 37 .

75. Id.

76. $I d$.

77. Gray's failure to explain the reasons for his warnings is particularly frustrating to me since his example of a dogmatic fiction, the attribution of will to abnormal human beings, is the subject of Part $\pi$ of this Article.

78. L. FULLER, supra note 4.

79. Id. at 8.

80. Id. at 11 . 
rious influence exercised by names and symbols." 81 That a statement which is disbelieved by both its user and his audience has any significance at all illustrates the "all-pervading power of the word." ${ }^{22}$ Furthermore, the legal fiction is a linguistic phenomenon in the sense that whether a statement qualifies as a fiction is "always, when examined critically, a question of the proprieties of language." 83

Under Fuller's definition, a statement must be false before it can be a fiction. His concept of truth was a pragmatic one. The truth of any statement is merely a question of its adequacy, whether it comes close to describing reality. Of course, no statement can really adequately describe reality. Fuller reserved the label of "false," however, for those statements that are outstanding or unusual in their inadequacy. If a statement does not even come close to describing reality, then the label of false would attach. That judgment is made with reference to standards of ordinary language usage. Once the label of "false" has attached, and the statement has been made with no intent to deceive, we have a legal fiction. ${ }^{84}$

Fuller used his linguistic analysis to distinguish between the benign and the "dangerous" legal fiction. The distinction rested upon the user's recognition of the statement's falsity. Under Fuller's formulation, the "danger" of a legal fiction varies inversely with the acuteness of the awareness that the assumption is false. A legal fiction is "wholly safe" only when the statement is used with "complete consciousness of its falsity"; ${ }^{85}$ the user of the fiction must be totally aware that the words do not adequately describe reality in some outstanding or unusual way. Fuller considered such a legal fiction benign; a legal fiction becomes "dangerous" only if the user is unaware of the falsity of the statement. One way to avoid this "danger" is for the user of the legal fiction to festoon it with a grammatical emblem of its falsity. This "assertive fiction," as Fuller called it, is similar to Gray's Roman historical fiction that bore the banner of "as if" on its sleeve. ${ }^{86}$

With both Gray and Fuller, their praise for the legal fiction was punctuated by warnings of danger. "Danger" is a very strong word. It conjures up images of potential loss of life or limb: cars without brakes; children toddling on the edges of cliffs; open razors; dark, steep stairs. Neither Fuller nor Gray shed much light on what they meant by danger. What were they warning us of? Do their cryptic admonitions have anything to do with Bentham's attack on the legal fiction? Is it just that legal fictions usurp legislative function, or are there other hidden dangers of which we should be aware?
81. Id. at 11 .
82. Id.
83. Id.
84. See id. at 11-12.
85. Id. at 10 .
86. Id. at 36-37. 
The questions raised by the historical debate on the legal fiction have gone unanswered. And for the most part, they have also gone unasked. The generation of legal scholars that followed Gray and Fuller did not continue the debate on the legal fiction, and it more or less came to an end.

It is now time to look at the history of a particular legal fiction, the doctrine of substituted judgment. In Part II, I present that history, and in Part III, I return to explore some of the questions raised by the historical debate on the legal fiction.

\section{The History of the DOCTRINE OF SUBSTituted JUdGMENT}

The doctrine of substituted judgment has its origins in the nineteenthcentury law of lunacy. English common law distinguished between two kinds of individuals who suffered from mental incapacity: the idiot and the lunatic. ${ }^{87}$ Crudely put, the lunatic was someone who had once possessed a sound mind and somehow lost it; the idiot never had one. The idiot's condition was static. He came into the world with a certain deficient mental apparatus and generally left it in the same way. For the idiot, there were no past periods of competency to hark back to, no future periods of competency to hope for. The lunatic, on the other hand, had once been competent and now experienced alternating periods of Iunacy and lucidity. The very word, "Iunatic," comes from the Latin "luna" or moon, and like the moon, the insanity of the lunatic waxed and waned..$^{88}$ Even a lunatic who appeared permanently insane was presumed potentially curable. He had once lived his life on equal mental footing with others, and there was always that glimmer of hope that he would do so again.

The earliest legal writing that distinguished between the idiot and the lunatic was a document sometimes referred to by later historians as the Statute De Prerogativa Regis. ${ }^{89}$ Prerogativa Regis was a product of the late thirteenth century, although it is not clear whether such a statute was ever enacted. Plucknett characterized the document called Prerogativa Regis as an "unofficial tract." $" 90$ Whatever its status, Prerogativa Regis described, if it did not in fact establish, the King's jurisdiction over the idiot and the Iunatic. Prerogativa Regis was primarily fiscal. Under Chapter IX, the King was given custody of the idiot's land, including the profits, with the limitation that he would not commit waste or destruction. Upon the idiot's death, the King was to render

87. 1 W. BLACKSTONE, COMMENTARIES *302.

88. Indeed, the collective wisdom for many centuries held that these cycles of sanity and insanity were intimately associated with the cycles of the moon. See L. SHELFORD, A PRACTICAL TREATISE ON THE LAW CONCERNING LUNATICS, IDIOTS, AND PERSONS OF UNSOUND MIND 3 (1833).

89. For a summary of how several historians, including Maitland and Sayles, describe the document Prerogativa Regis, see T. PLUCKNETT, A CONCISE HISTORY OF THE COMMON LAW 542 n.2 (5th ed. 1956). 90. Id. at 542 . 
the estate to his heirs. ${ }^{91}$ This arrangement filled the royal coffers, and at the same time kept the idiot from disinheriting his family.

The King did not have the same degree of control over the property of the lunatic, however. Because of the presumption that the lunatic might regain his sanity, the law treated his property differently. Under Prerogativa Regis, the King was not given custody of the lunatic's land; nor was he permitted to take any profit for his own use. Instead, the King had the duty to provide that the land of the lunatic was safely kept without waste and destruction, and that the profits were used solely for the lunatic's support and maintenance. Once the lunatic recovered his right mind or experienced a lucid interval, the land and profits were to be returned to him. If the lunatic died without ever regaining his sanity, his property would descend to his heirs. Prerogativa Regis therefore bid the King to keep his royal hands off the estate of the lunatic, unlike the sanctioned taking of the idiot's profits. Furthermore, Prerogativa Regis imposed a duty on the King to maintain the lunatic, on the off chance that he might return to his senses. ${ }^{92}$

There were obviously too many lunatics for the King to personally take care of the person and property of each and every one. The history of how the royal duty toward the lunatic was discharged over the centuries is murky and beyond the scope of this Article. Since we are about to settle into the early nineteenthcentury law of lunacy, however, it is relevant to look at what the jurists of that day thought about the Chancellor's jurisdiction over the lunatic and his estate. The most frequently cited work on the subject of jurisdiction was a treatise written in 1833 by a barrister named Shelford. ${ }^{93}$ Shelford's Treatise was not

91. Prerogativa Regis, 1324, 17 Edw. 2, ch. 9:

The Custody of Lands of Idiots. The King shall have the Custody of the Lands of natural Fools, taking the Profits of them without Waste or Destruction, and shall find them their Necessaries, of whose Fee soever the Lands be holden; and after the Death of such Idiots he shall render it to the right Heirs, so that such Idiots shall not align, nor their Heirs shall be disinherited.

Prerogativa Regis embodied feudal custom that based tenure on military service. Since the idiot would never be able to meet his military obligations, the King was given his fiscal prerogative to reimburse himself for the certain loss of services. The bargain was not altogether unfair, however, since the idiot's support and maintenance was to be paid for out of the proceeds of the land. There was thus a kind of rough quid pro quo. See 1 F. WHARTON \& M. STILLE, WHARTON AND STILLE'S MEDICAL JURISPRUDENCE 483 (5th ed. 1905).

92. Prerogativa Regis, 1324, 17 Edw. 2, ch. 10:

Of Lands of Lunatics. Also the King shall provide, when any (that before time hath had his Wit and Memory) happen to fail of his Wit, as there are many per Iucida intervalla that their Lands and Tenements shall be safely kept without Waste and Destruction, and that they and their Household shall live and be maintained competently with the Profits of the same, and the Residue besides their Sustenation shall be kept to their Use, to be delivered unto them when they come to right Mind; so that such Lands and Tenements shall in no wise be aliened; and the King shall take nothing to his own Use. And if the Party die in such estate, then the Residue shall be distributed for his soul by the Advice of the Ordinary.

93. L. SHELFORD, A PRACTICAL TREATISE ON THE LAW CONCERNING LUNATICS, IDIOTS, AND PERSONS OF UNSOUND MIND (1833). Despite the fact that Shelford's Treatise was published in the United States, it only discussed the law of England, Ireland, and Scotland. Shelford's popularity extended beyond the boundaries of the British Isles and outlived the 19th century. His Treatise has been frequently cited in cases during the present century. See, e.g., Kelley v. Scott, 215 Md. 530, 533, 137 A.2d 704, 706 (1958); In re 
the first book written on the law of lunacy, but it was the most scholarly work of its time. ${ }^{94}$ Shelford was among those who believed that Prerogativa Regis was a duly enacted statute of the Realm and the source of the King's duty to the lunatic. Shelford referred to the King as the "political father and guardian of his kingdom," invoking the doctrine of parens patriae. ${ }^{95}$ Parens patriae literally means "parent of the country" and refers to the sovereign's role as guardian of persons under legal disabilities. ${ }^{96}$

With respect to infants, the King delegated his parens patriae authority to the Court of Chancery, although there is considerable controversy over how that delegation took place..$^{97}$ Shelford characterized the jurisdiction of the Chancellor over infants as equitable in nature. The Chancellor was merely discharging the King's duty to protect and care for those subjects "who are uncapable to take care of themselves." 98

Shelford took a different position with respect to the jurisdiction of the Chancellor over lunatics, however. In the case of infants, Shelford explained, "the Lord Chancellor is acting as the Court of Chancery; not so in lunacy; but under a special separate commission from the crown, authorizing him to take care of the property, and for the benefit of the lunatic." 99 By sign manual, the King had authorized the Keeper of the Great Seal to discharge his duties under Prerogativa Regis. ${ }^{100}$ The King's warrant conferred no equitable jurisdiction upon the Court of Chancery. Instead, the Chancellor himself, personally, had only a "power of administration" over the lunatic. ${ }^{101}$

Schley, 201 Misc. 522, 527, 107 N.Y.S.2d 884, 889 (1951); In re Fleming's Estate, 173 Misc. 851, 854, 19 N.Y.S.2d 234, 237 (1940).

94. Shelford mentions two earlier treatises on lunacy law in his preface: A. HIGHMORE, A TREATISE ON THE LAW OF IDIOCY AND LUNACY (1807) and COLLINSON, TREATISE ON LAW CONCERNING IDIOTS, LUNATICS, AND OTHER PERSONS NON COMPOS MENTIS (1812). Shelford writes that these two treatises, "though extremely useful at the time of their publication, have now become very insufficient guides, in consequence of the changes which the law has undergone." L. SHELFORD, supra note 88, at iv.

95. Id. at 6.

96. BLACK's LAW DICTIONARY 1003 (5th ed. 1979).

In our own century, we tend to take the doctrine of parens patriae for granted, but it did not really solidify into precedent until the early 18 th century. By the middle 19 th century, however, the doctrine of parens patriae was firmly entrenched, and Shelford probably regarded it as a permanent fixture of English law. See Custer, The Origins of the Doctrine of Parens Patriae, 27 EMORY L.J. 195, 206 (1978).

97. See Custer, supra note 96, at 206-07.

It is interesting to note that Lord Eldon, the creator of the legal fiction in Ex parte Whitbread, 2 Meriv. 99, 35 Eng. Rep. 878 (Ch. 1816), see infra notes 103-11 and accompanying text, was responsible for finalizing judicial recognition of the Chancery's jurisdiction over infants. In DeManneville v. DeManneville, 32 Eng. Rep. 762 (Ch. 1804), Lord Eldon acknowledged that the equity court's jurisdiction over the person of the child or to "control the right of the father" may have stood on historically shaky ground, but he stated that "[i]n whatever principle that right is founded, it is unquestionably established; and is not disputed." Id. at 767 .

98. Eyre v. Shaftsbury, 24 Eng. Rep. 659, 664 (Ch. 1722).

99. L. SHELFORD, supra note 88 , at 10.

100. Id.

101. Id. Under Prerogativa Regis, the King alone had the power to:

grant the custody of the idiot or lunatic and his estates, by sign manual; and, therefore, to save repeated applications to the Crown, it has been the practice for the Crown to intrust such power by warrant under the sign manual, countersigned by the two secretaries of state, to the Lord 
Even though the King's warrant only gave the Chancellor the power to provide for the maintenance and preservation of the lunatic and his estate, in practice the Chancellor often went beyond these "powers of administration." As Joseph Story explained, "After the custody is so granted, and maintenance is assigned, the chancellor acts in other matters, relative to lunatics at least, not under the warrant by the sign-manual, but in virtue of his general power, as holding the great seal, and keeper of the king's conscience."102 In effect, the Chancellor exercised equitable jurisdiction over the lunatic.

It was through the exercise of this equitable jurisdiction that the doctrine of substituted judgment was introduced. Ex parte Whitbread ${ }^{103}$ was the seminal decision. The lunatic in question was a Mr. Hinde, and the year was 1816. The Chancellor who sat in the Court of Chancery at that time was Lord Eldon. Lord Eldon had ordered a Master to inquire into whether any increase should be made to an allowance for the maintenance and support of Mr. Hinde. ${ }^{104}$ In making this inquiry, the Master was called upon to consider not only the circumstances and estate of the lunatic, but also "the situation of his immediate relations." 105 In his report, the Master certified his opinion that Mr. Hinde's allowance should be increased from 1200 pounds to 2000 pounds. Out of the increased allowance, the Master submitted that "several yearly payments" should be made to "the Lunatic's immediate relations." 106 The facts do not disclose who these immediate relations were, but the propriety of the payments was not questioned. Since there were no objections to the Master's report, the Chancellor ordered it to be confirmed, probably as a matter of course.

Before the order was drawn up, however, a petition was filed "by a niece of the Lunatic, one of the immediate relations provided for by the Report, who conceived herself aggrieved by the Master's apportionment." ${ }^{107}$ Her petition prayed that the report not be confirmed regarding the allocation of Mr. Hinde's allowance among his immediate relations; it further prayed that the niece receive a different "proportion of the said allowance." 108 While the decision

Chancellor, on his coming into office; by virtue of which warrant, and not as Chancellor, he has the ordering and disposition of the persons and estates of idiots and lunatics; and such warrant Id. confers no jurisdiction, but only a power of administration.

Another writer points out that custody of idiots and Iunatics was lodged by special warrant in the Lord keeper of the Great Seal. The Lord keeper of the Great Seal, however, is always the Lord Chancellor. See 1 F. WHARTON \& M. STILLE, supra note 91 , at 483.

102. $2 \mathrm{~J}$. STORY, COMMENTARIES ON EQUTTY JURISPRUDENCE AS ADMINISTERED IN ENGLAND AND AMIERICA 608 (12th ed. 1877).

103. Ex parte Whitbread, 2 Meriv. 99, 35 Eng. Rep. 878 (Ch. 1816).

104. A Master was a court official who assisted the Chancellor in his judicial work. For a discussion of the Masters in Chancery, in particular the office of the Master of the Rolls, see T. PLUCKNETT, supra note 89 , at 209.

105. Whitbread, 2 Meriv. at 99, 35 Eng. Rep. at 878.

106. Id.

107. Id. at 99-100, 35 Eng. Rep. at 878 .

108. Id. at 100, 35 Eng. Rep. at 878. 
did not mention the amount of her request, it was clear that the niece was asking for more money.

The niece's petition made the Chancellor exceedingly uncomfortable. We know this from a decision reported twenty years later in which one of the litigants involved in Whitbread "recollected that Lord Eldon felt very great difficulty in acceding to an application similar to the present; the matter was several times mentioned to Lord Eldon, and he repeatedly answered by asking what power he had to give away the property of a lunatic."109 Lord Eldon was concerned by the petitioner's tenuous relationship with Mr. Hinde. As a mere niece, she was in no way a person to whom Mr. Hinde owed a duty of support. Lord Eldon held firm that a niece had no "right to an allowance" from the lunatic. She was, after all, only his "next of kin."110

Even then, Lord Eldon was mistaken when he referred to Mr. Hinde's niece as his "next of kin." The mistake may seem only a terminological misdemeanor, but its implications are of felonious grandeur. The term "next of kin" denotes a class of persons who are most nearly related by blood to a decedent, and Mr. Hinde was not yet dead. Indeed, Lord Eldon's discomfort with the niece's petition stemmed from the very fact that Mr. Hinde was still alive. Lord Eldon had dealt with the relatives of lunatics before, and he even complained about the frequency with which such relatives struggled "among them to reduce the amount of the allowance made for the Lunatic, and thereby enlarge the fund which, it is probable, may one day devolve upon themselves."111 In Whitbread the niece was not seeking to reduce the amount of Mr. Hinde's allowance. Instead, she wanted some of the surplus income to be distributed to her before he had achieved the ultimate status of decedent.

It is not difficult to see the source of Lord Eldon's conflict. The niece was pleading for her uncle's property, and property was something that Lord Eldon felt strongly about. As a jurist of the early nineteenth century, Lord Eldon was still wedded to Blackstone's notion of property, which was rooted in classical liberal thought. ${ }^{112}$ The most salient feature of liberalism was its division of the universe into two separate spheres of state power and individual freedom. A boundary lay between the two. In order to protect the individual from encroachment by the state into his sphere of freedom, the law appointed certain categories of legal thought to stand guard. By labeling a thing as property, the law marked out the limits of state power. ${ }^{113}$ Blackstone echoed Montesquieu

109. In re Blair, 1 Myl. \& Cr. 300, 303, 40 Eng. Rep. 390, 391 (Ch. 1836).

110. Whitbread, 2 Meriv. at 102-03, 35 Eng. Rep. at 879.

111. Id. at 101-02, 35 Eng. Rep. at 879.

112. See generally Kennedy, The Structure of Blackstone's Commentaries, 28 BUFfaLO L. REV. 209 (1979).

113. See Vandevelde, The New Property of the Nineteenth Century: The Development of the Modern Concept of Property, 29 BUFFALO L. REv. 325, 327-28 (1980). 
in claiming that the state must not tamper with a man's property; no public good could be greater than a man's right to hold on to his own. ${ }^{114}$

But labeling something as property did more than just keep the state at bay. It also created a relation between the property owner and everyone else with respect to that something. Prior to his lunacy, Mr. Hinde had absolute dominion and control over his bank account. He could have invested his money. He could have squandered his money. He could have sat on his money. He could even have given his money away, either by inter vivos transfer or testamentary bequest. ${ }^{115}$ Blackstone placed a high premium on these rights flowing from ownership; he considered property one of three "absolute right(s) inherent in every Englishman."116 Blackstone's tradition, to which Lord Eldon belonged, ${ }^{117}$ would not tolerate any infringement by others of a property owner's rights. To say that the contents of Mr. Hinde's bank account constituted his property was to say that the state would enforce his right to exclude others from taking, using, or even just fondling his cash. It was Mr. Hinde's to do with as he pleased, and he was at liberty to turn a deaf ear to the supplications of destitute nieces.

But Mr. Hinde was a lunatic. This meant that he lacked the capacity to exercise absolute dominion and control over his bank account. The Chancellor had the duty to protect Mr. Hinde's property, or in the language of Prerogativa Regis, to "safely keep" his estate. ${ }^{118}$ Furthermore, in Whitbread Lord Eldon referred to a principle that "where any allowance is made for the family of a Lunatic, it is upon the principle of tenderness toward the Lunatic himself."119 It is difficult to imagine how taking Mr. Hinde's money out of his bank account and giving it to his niece could constitute either a safekeeping of his estate or tenderness toward the lunatic himself. Most people charged with the Chancellor's duty would consider the proper course of conduct to be one which increases the estate, or at a minimum, conserves it-one which makes the pot grow larger through a plan of investment, or maintains the pot through a policy of savings, but does not give the pot away.

The facts in Whitbread provided a moist and rich soil for a legal fiction to grow in. Lord Eldon's fidelity to the principles of property and his duty to

114. See 2 MONTESQUIEU, THE SPIRT OF THE LAWS $72-73$ (T. Nugent ed. 1949).

115. An inter vivos transfer is one made from one living person to another. It takes effect while the donor is living. In contrast, a testamentary gift is one which takes effect on the death of the donor. BLACK'S LAW DICTIONARY 737 (5th ed. 1979).

116. I W. BLACKSTONE COMMENTARIES *134. The other two absolute rights were life and liberty.

117. Plucknett tells us that Lord Eldon was the son of a prosperous tradesman of Newcastle. He was educated at Oxford, studied law, and devoted himself to a thriving equity practice. He became involved in politics, first entering Parliament and then becoming Solicitor-General in 1788. In 1799, he became Lord Chief Justice of the Court of Common Pleas and was raised to the peerage as Baron Eldon. Two years later, he became the Chancellor and sat for another twenty years. Plucknett characterizes him as "a conservative of the most uncompromising type." T. PLUCKNETT, supra note 89, at 633-34.

118. See supra note 92.

119. Ex parte Whitbread, 2 Meriv. 99, 101, 35 Eng. Rep. 878, 878 (Ch. 1816). 
protect the lunatic's estate should have dictated a denial of the niece's request. Yet Lord Eldon must have been persuaded. After all, Mr. Hinde was presently incapable of enjoying the money in his bank account, and the presumption that he might regain his senses was probably itself a fiction. By all appearances, Mr. Hinde was being well cared for, and the allowance was to go to a prospective legatee. And perhaps the niece was a sympathetic petitioner. She may have been destitute, too ill to work, or the mother of hungry children. We do not know the circumstances of her need. All we really know, and this only by inference, is that Lord Eldon was inclined to grant her petition.

Granting her petition, however, presented Lord Eldon with a conflict. He would either have to sacrifice the beloved principles of property or admit to being derelict in his duties toward the lunatic and his estate. By sanctioning this rather blatant redistribution of Mr. Hinde's wealth, Lord Eldon would implicitly be saying, "His money is not property," or "His money is property, and I am going to give it away." Neither statement could be made without justification, and inevitably there would be casualties. Either the existing law of property would have to be changed, or Lord Eldon would have to bring dishonor upon himself and the Office of the Chancellor. The stakes were just too high.

How did Lord Eldon resolve this conflict? He crafted a legal fiction. This legal fiction enabled him to achieve the desired result of granting the niece's petition while still preserving the law of property and the integrity of the Chancellor. He started out by reiterating the principle of tenderness to the lunatic: "Nevertheless, the Court, in making the allowance, has nothing to consider but the situation of the Lunatic himself, always looking to the probability of his recovery, and never regarding the interest of the next of kin."120 Lord Eldon then did a remarkable thing. In considering the lunatic's situation, he changed his perspective from an external point of view to an internal, subjective one. To achieve this change in perspective, Lord Eldon had to relinquish his position of judicial objectivity and enter the lunatic's mind. Once inside, the Chancellor had to look around and discover what the lunatic himself probably would have done. Once the probable desires of the lunatic were discovered, the Chancellor had to carry them out:

We find that it is not because the parties are next of kin of the Lunatic, or, as such, have any right to an allowance, but because the Court will not refuse to do, for the benefit of the Lunatic, that which it is probable the Lunatic himself would have done. ${ }^{121}$

With respect to Mr. Hinde, Lord Eldon was on a mission to unearth the donative intent needed to make an allowance to the petitioner. $\mathrm{He}$ found it,

120. Id. at 102, 35 Eng. Rep. at 879.

121. Id. 
lodged beneath some alleged humiliation that Mr. Hinde would feel should his niece and her family "be sent into the world to disgrace him as beggars." 122 The allowance would "naturally be more agreeable to the Lunatic, and more for his advantage, that they should receive an education and maintenance suitable to his condition." 123 Lord Eldon then referred the petition back to the Master with an order to distribute more of Mr. Hinde's money to the niece. Lord Eldon even claimed that the increased allowance would not result in a diminution of Mr. Hinde's estate and that "if he recovers, he shall find his estate as nearly as possible in the same condition as he left it." 124 Lord Eldon did not explain how this could be done-how he could slowly drain the bowl of water and still promise the goldfish a place to swim.

While Lord Eldon purported to enter the mind of the lunatic, he seemed to have made no effort to discover what had once been in Mr. Hinde's mind. The Whitbread decision does not mention any evidence of Mr. Hinde's prior spending practices or his propensity for making gifts. Nor was the relationship between Mr. Hinde and his niece examined. We do not know if he had formerly considered her the natural object of his bounty. There were no warm letters quoted, no testimony about frequent visits or a history of making allowances, or any other manifestations of niecely affection or avuncular solicitude. Rather, we get a rather bald assertion from Lord Eldon that granting the niece an allowance is only what Mr. Hinde himself would do "if he were in a capacity to exercise any discretion on the subject," 125 and that granting the niece an allowance is only "wise and prudent." ${ }^{126}$ Instead of discovering anything about Mr. Hinde and his former internal, subjective point of view, Lord Eldon seems to have just looked around and found a generic, reasonable lunatic-a generic, reasonable lunatic prone to giving his money away. ${ }^{127}$

It can hardly be said that Lord Eldon's legal fiction captured the imagination of subsequent English jurists. Whitbread was only cited in a dozen or so Chancery decisions throughout the nineteenth century. All of them presented fact patterns similar to the one in Whitbread: relatives of rich lunatics petitioning the Chancellor for allowances of "surplus income." Sometimes the decisions

\section{Id.}

123. Id.

124. Id. at 102-03, 35 Eng. Rep. at 879 .

125. Id. at 100 note a, 35 Eng. Rep. at 878.

126. Id. at 102-03, 35 Eng. Rep. at 879.

127. See Robertson, Organ Donations by Incompetents and the Substituted Judgment Doctrine, 76 COLUM. L. REV. 48, 61 n.73 (1976).

The authors of an early law review article on the lunatic's surplus income also characterized the lunatic in Whitbread as a "reasonable" man. About the principle laid down by Lord Eldon in Whitbread, Thompson and Hale wrote:

[T] hat principle, it is submitted, is this. Where there is no evidence of any settled intention of the lunatic before his insanity in regard to the matter, or of any intention formed during his rational moments, the court will presume that were the lunatic sane, he would act in the matter as any reasonable and ordinary generous man would act under the same circumstances.

Thompson \& Hale, The Surplus Income of a Lunatic, 8 HARV. L. REV. 472, 473 (1895). 
just assumed that the Chancellor had the authority to grant allowances to peripheral family members; Whitbread was not cited. ${ }^{128}$ At other times, Whitbread was cited as authority, but with no mention of the legal fiction of doing that "which it is probable the lunatic himself would have done."129 Other decisions employed the language of the legal fiction, but did not bother to cite Whitbread..$^{130}$ And finally, a handful of decisions actually cited Whitbread as authority and expressly used the language of the legal fiction to grant allowances to the lunatic's distant relations. ${ }^{131}$ Thus, while Lord Eldon's legal fiction eventually became precedent, the immediate judicial response was lukewarm, to say the least.

What we do see from the decisions is a trend toward limiting the power of the Chancellor to give the lunatic's money away. Lord Eldon's legal fiction seemed to generate judicial distrust. In In re Blair, the first case to cite Whitbread (some twenty years after it had been decided), the Chancellor expressed concern that this authority be exercised with the "greatest possible jealousy and caution." ${ }^{132}$ Referring to Lord Eldon's "great difficulty" in granting the niece's petition in Whitbread, the Chancellor went on to say:

Lord Eldon did, at last, accede to the prayer of the petition in that case, and the precedent which he had so made had been followed in several subsequent instances. The practice, however, was one which could not be regarded with too much caution, and the principle involved in it ought to be narrowed rather than extended in its operation .... ${ }^{133}$

Later decisions echoed this warning about the potential abuses of purporting to do that which it is probable the lunatic himself would have done. There

128. E.g., In re Weld, 20 Ch. D. 451 (C.A. 1882); In re Clarke, 2 Ph. 282, 41 Eng. Rep. 951 (Ch. 1847); In re Grove, 13 L.J.N.S. 262 (Ch. 1844); Ex parte Fowler, 6 Jur. 431 (Ch. 1842); In re Drummond, 1 Myl. \& Cr. 627, 40 Eng. Rep. 516 (Ch. 1836).

129. E.g., In re Strickland, 6 L.R. Ch. App. 225, 226 (1871); Ex parte Haycock, 5 Russ. 154, 154, 38 Eng. Rep. 985 (Ch. 1828).

130. E.g., In re Frost, 5 L.R. Ch. App. 699 (1870); In re Hewson, 21 L.J. Eq. 825 (Ch. 1852).

In one decision, the Chancellor granted a retirement pension to an elderly and infirm servant who had been in the lunatic's employment for over 20 years. When the Chancellor asked counsel for the petitioner if there was any precedent for granting such a pension, counsel answered on the next day that "no precedent could be found, but that he was instructed to say, on behalf of the committees, that they were satisfied that the allowance was one which the lunatic, if he should ever recover, would approve; and the Lord Chancellor made the order." In re Earl of Carysfort, Cr. \& Ph. 76, 77, 41 Eng. Rep. 418, 418 (Ch. 1840). This was a slightly different formulation of Lord Eldon's legal fiction, which was based on what the lunatic would probably have done when faced with the present petition. The legal fiction in Carysfort was based on what the lunatic would ratify in the future when faced with the Chancellor's decision on the present petition. Carysfort is frequently cited in later cases as derivative of Whitbread, despite the fact that the Chancellor and the litigants seemed unfamiliar with that decision.

131. E.g., In re Darling, 39 L.R. Ch. D. 208, 210 (C.A. 1888); In re Sparrow, 20 L.R. Ch. D. 320, 321 (C.A. 1882); In re Evans, 21 L.R. Ch. D. 297, 298-300 (C.A. 1882); In re Croft, 32 L.J. Eq. 481, 481, 139 Rev. Rep. 348, 348 (Ch. 1862); In re Blair, 1 Myl. \& Cr. 300, 303, 40 Eng. Rep. 390, 391 (Ch. 1836). 132. Blair, 1 Myl. \& Cr. at 303, 40 Eng. Rep. at 391.

133. Id. 
seemed to be discomfort with Lord Eldon's generic, reasonable lunatic prone to giving his money away. Evidentiary constraints came to be imposed upon the use of the legal fiction. Evidence of a close family connection was one such constraint. In In re Evans, for example, the Chancellor denied the petition of a sympathetic first cousin of the lunatic, an eighty-one-year-old clergyman who was in "distressed circumstances" and "a very fit object of charity." 134 Quoting the language of Lord Eldon's legal fiction, the Chancellor pointed out that the lunatic had probably never even known of the petitioner's existence, "but it would not alter my judgment if it were shewn that he did." 135 What really bothered the Chancellor in Evans was the fact that the petitioner and the lunatic were only first cousins. After all, Lord Eldon had fabricated feelings of disgrace on the part of Mr. Hinde for his niece's destitution, and those feelings had prompted Lord Eldon to grant the petition. The Chancellor in Evans simply could not conjure up similar feelings of disgrace for his lunatic:

The guiding principle then is the benefit of the lunatic, and the allowance is made because it would be a disgrace to him that certain near relatives should not be maintained and educated. But it has never been said that it would be a disgrace to a lunatic that his cousins should not be maintained and educated, nor that it is to be presumed that it is a matter of interest to him what becomes of his first cousins. ${ }^{136}$

Unlike nieces, first cousins were deemed too distantly related to warrant a finding of fictional guilt. ${ }^{137}$

The closeness of the family connection was not the only kind of evidence that the Chancellors sought. Evidence of the lunatic's former intentional states became of paramount importance. In In re Frost, for example, the Chancellor emphasized that the lunatic had expressed her intent to provide for the petitioners before losing her capacity. ${ }^{138}$ Similarly, a history of the lunatic's making gifts to the petitioner was evidence from which to infer probable donative intent. Sometimes the petition prayed for an increase in an allowance made to the petitioner prior to the commission of lunacy. In In re Darling, such a petition was filed, ${ }^{139}$ and the Chancellor refused to increase the amount. ${ }^{140}$

134. Evans, 21 L.R. Ch. D. at 299.

135. Id. at 301 .

136. Id. at 300 .

137. Cf. In re Croft, 32 L.J. Eq. 481 (Ch. 1862). In Croft, there was no evidence of any intimacy between the petitioner and the lunatic, who were first cousins as well. Still, the Chancellor granted the petition. The advanced age of the petitioner, his dire poverty, and the lack of public assistance were cited as reasons for making the allowance. One Lord Justice insisted that the petitioner account for the amount given "against his expectant share in the estate of the lunatic," and that the case "ought not be drawn into a precedent." Id. at 482,139 Rev. Rep. at 349.

138. 5 L.R. Ch. App. 699 (1870).

139. For a discussion of the procedures involved in a 19th-century commission of lunacy, see $L$. SHELFORD, supra note 88 , at $74-130$.

140. In re Darling, 39 L.R. Ch. D. 208, 208 (C.A. 1888). 
The allowance provided evidence of how much the lunatic intended to give, and the Chancellor did not feel authorized to give much more: "[I]t is not our business to deal benevolently or charitably with the property of the lunatic, and in my opinion it would be wrong for us to do so."141

The power of the Chancellor to give the lunatic's money away had thus been restricted. In 1816, when Whitbread was decided, there were no evidentiary constraints imposed upon the Chancellor's search for probable donative intent. Lord Eldon had felt free to crawl into Mr. Hinde's mind and find whatever he wanted to. This freedom was soon curtailed. Subsequent Chancellors looked for a degree of consanguinity, a history of prior warmth and affection, perhaps statements made by the lunatic of his intent to make gifts to the petitioner, or even evidence of past gift-giving on which to hang a moral obligation. ${ }^{142} \mathrm{He}$ was no longer a generic, reasonable lunatic prone to giving his money away. Instead, he was a specific individual with a past that had to be consulted. His probable donative intent to make the allowance may have been bogus, but there still had to be sufficient evidence of former donative inclinations to justify granting the petition.

Lord Eldon's legal fiction crossed the Atlantic in 1844. In In re Willoughby the New York Chancellor recognized the power of an equity court to make allowances out of a lunatic's surplus income for the "maintenance of the relatives of such lunatic who have no legal claims upon him or his estate."143 Citing Whitbread and a few of its progeny, the Chancellor claimed that the equity court could act "for the lunatic, and in reference to his estate, as it supposes the lunatic himself would have acted if he had been of sound mind."144

The words of warning from Blair were invoked in Willoughby: "[T]he practice which had been introduced by Lord Eldon, and subsequently followed, was one which could not be regarded with too much caution."145 In fact, the petition in Willoughby was denied. The lunatic's wife had asked for an allow-

141. Id. at 211.

142. "A similar principle would apply if the lunatic had been in the habit of making an allowance while sane, in which case a moral obligation would arise, for the recipient no doubt would regulate his mode of life on the faith of its being continued." In re Evans, 21 L.R. Ch. D. 297, 301 (C.A. 1882).

143. In re Willoughby, 11 Paige Ch. 257, 259 (N.Y. Ch. 1844). The Chancellor in Willoughby noted that orders making allowances to persons whom the lunatic was not obligated to support had

been made by this court, within the last fifteen years, in three or four different cases; where the estates were large and the incomes much more than sufficient for the support of the lunatics, and of all those who had a legal claim upon such lunatics for support and maintenance. But my present recollection is, that in all those cases, I required the adult children, who were competent to support themselves, to give a stipulation that the amounts advanced to them respectively should be brought into hotchpot, upon the death of the lunatic; if any part of his personal estate should come to them under the statute of distributions.

$I d$. at 259 . The Chancellor's comments suggest that these allowances from the lunatic's surplus income were nothing more than premature testamentary dispositions.

144. Id. Shelford's Treatise also crossed the Atlantic with Whitbread in 1844. The New York Chancellor in Willoughby cited the Treatise as authority for the use of Lord Eldon's legal fiction. See id.

145. Id. at 260 . 
ance for her daughter by a former husband, and the New York Chancellor was not convinced that the lunatic would have made the gift:

Under the circumstances ... I am not satisfied that he would consider her as having such a claim upon his bounty, if he was restored to his reason so as to be capable of acting with sense and discretion. From the affidavits, read in opposition to this application, it appears that he did not consider her as entitled to a support from him, or as standing in the situation of an adopted child. ${ }^{146}$

Thus the first Chancellor in this country to recognize the power of an equity court to give the lunatic's money away did not exercise that power. Lord Eldon's legal fiction may have crossed the Atlantic, but the baggage of evidentiary constraints imposed upon its application made the journey as well.

In this country, those evidentiary constraints became an integral part of the legal fiction, even more than in England. Three years after Willoughby was decided, the same New York Chancellor granted a similar petition for allowances from a lunatic's surplus income. In re Heeney probably marks the outer boundaries of permissible judicial gift-giving on behalf of a lunatic. ${ }^{147}$ Mr. Heeney was an elderly, senile bachelor with lots of money. He had supported a number of women over the years, including his three unmarried sisters, two young women whom he had adopted, and "three aged ladies, whom he had sent to Europe in their younger days, and supported in his house until they were married."148 Mr. Heeney was "also in the habit of spending the whole of the residue of his income in acts of benevolence and charity and piety."149 The petition prayed for the continuation of support for these various beneficiaries of Mr. Heeney's largess. ${ }^{150}$

The New York Chancellor granted the petition in Heeney, citing his earlier decision in Willoughby in which he had concluded that the equity court had the power to make such allowances. While the Chancellor did not cite Whitbread, ${ }^{151}$ he used a variation of Lord Eldon's fiction, that the Chancellor could make the gift where he was "satisfied, beyond all reasonable doubt, that the lunatic himself would have provided for the support of such person if he had been of sound mind, so as to be legally competent to do so."152

146. Id. The New York Chancellor also pointed out that the stepdaughter could support herself, adding the petitioner's need to the list of factors that the equity court could consider.

147. In re Heeney, 2 Barb. Ch. 326 (N.Y. Ch. 1847).

148. Id. at 327.

149. Id.

150. One of the sisters was still alive. Mr. Heeney had supported her for 40 years, allowing her $\$ 250$ a year, in addition to paying for her clothing, medical care, and other necessary items. After the "three aged ladies" had lost their husbands, Mr. Heeney had resumed responsibility for their support.

151. It is interesting to note that in both Willoughby and Heeney, the New York Chancellor cited Carysfort, which had a slightly different formulation of Lord Eldon's legal fiction. See supra note 130. The language of the legal fiction used in Heeney seems to have come from Whitbread, however.

152. In re Heeney, 2 Barb. Ch. 326, 328 (N.Y. Ch. 1847). 
The New York Chancellor relied upon evidence of the lunatic's prior generosity, finding that Mr. Heeney had "been in the habit" of giving to these various donees. ${ }^{153}$ All of the petitioners fared well. Even Mr. Heeney's various religious organizations benefited. The Chancellor authorized the committee to make gifts to Mr. Heeney's "institutions of religion," not to exceed the amount he had given for the two or three years prior to the declaration of his lunacy, or the annual sum of $\$ 100 .{ }^{154}$ The Chancellor was scrupulous in his efforts to make the same allowances that Mr. Heeney himself had made before losing his capacity. It may be true that when the Chancellor went looking for Mr. Heeney's probable donative intent, he struck it rich. But then again, the evidence tended to show that Mr. Heeney had been a giving man, a very giving man indeed.

As had been the experience in England, Lord Eldon's legal fiction hardly swept American jurists off their feet. In fact, Whitbread was not cited in any other reported American cases in the nineteenth century. Lord Eldon's legal fiction surfaced again in New York in 1914. In In re Kernochan a nephew petitioned an equity court for a generous allowance of $\$ 12,000$ a year from his elderly aunt's surplus income. ${ }^{155}$ By this time, however, the terminology had changed, and the law of lunacy had been left behind. The aunt in Kernochan was now simply referred to as an "incompetent." The label no longer discriminated between the different types of mental incapacity; there was no way to tell whether its bearer had ever been of sound mind. Once again, the evidentiary constraints upon the use of the legal fiction were imposed, and the nephew's petition was denied. The court acknowledged in Kernochan that the aunt's money was just gathering dust, that she was "incurable, sixty-five years of age, without issue, never having been married, and has been insane since 1872; that her surplus income annually amounts to $\$ 100,000$," and that her apparent heirs included the petitioner's mother. ${ }^{156}$ These facts alone, however, did not justify giving her money away. Since the aunt had become insane some eight years prior to the petitioner's birth, there could be no evidence that she was predisposed toward him as a donee. The nephew's failure to exist during her period

153. Id. at 330 .

154. Id.

155. In re Kernochan, 84 Misc. 565, 146 N.Y.S. 1026 (1914). The facts in Kernochan provide some insight into what a wealthy young man's notion of deprivation consisted of in 1914 . The petitioner was 33 years old and came from a wealthy family. His mother's estate was worth over $\$ 1,000,000$, and she had 12 servants in her city home and 25 in her country home. Another aunt had an estate of $\$ 2,525,000$, and the incompetent aunt's surplus income amounted to $\$ 100,000$ a year. The petitioner had "lived an idle and luxurious life." Id. at 566, 146 N.Y.S. at 1027. He had pursued a career in songwriting which produced $\$ 30$ a year in income, while the advertising costs for his songs and one cantata amounted to $\$ 175$ a year. He belonged to 12 clubs: the Union, Brook, Racquet, Knickerbocker, Grolier, Players, Tuxedo, Lenox, Pittsfield Country Club, Stockbridge, the Tennis Club, and the Automobile Club. He claimed that if the allowance were not granted, he would have to resign from all his clubs except the Union and the Knickerbocker. Furthermore, he would have to give up his chauffeured car and his dream of making an advantageous marriage. Id. at 567-68, 146 N.Y.S. at 1027. Life can be so cruel.

156. Id. at 571, 146 N.Y.S. at 1029. 
of competency had defeated his petition. While the petition was denied, the equity court in Kernochan did conclude that it had the power to make such an allowance from an incompetent's surplus income. ${ }^{157}$ Lord Eldon's legal fiction was introduced into the common law again, and in the twentieth century, it picked up steam.

How Lord Eldon's legal fiction solidified into established doctrine in this country would be great grist for the law review mill. It is an eminently researchable subject about which there is very little interesting to say. The cases are still worth reading, however. Many of them are fascinating on a human level, with fact patterns that often hint at the darker side of the American family: a stark lunar surface of guilt and greed. The New York courts were the most frequent and indiscriminate users of the legal fiction. ${ }^{158}$ In New York, however, there was no further development of the doctrine. The language of Lord Eldon's legal fiction remained essentially the same, as did the evidentiary constraints imposed upon its application. New York judges continued to require evidence of close family ties, mutual affection, prior donative intent, or a history of generosity.

Beyond the boundaries of New York, Lord Eldon's legal fiction did not become firmly entrenched. Judges in other parts of the country continued to be disturbed by the very question that had caused Lord Eldon to squirm: by what authority did an equity court have the power to give the incompetent's money away? Those judges that considered the question found awkward

157. The court in Kernochan relied upon Whitbread, several later English cases, Shelford's Treatise, Willoughby, and Heeney as authority for its position that equity courts have the power to make allowances out of the incompetent's surplus income for individuals to whom the incompetent had no duty of support. Id. at 569-70, 146 N.Y.S. at 1028-29.

158. See, e.g., In re Flagler, 248 N.Y. 415, 420, 419, 162 N.E. 471, 472 (1928) (petition granted for "barest needs" of incompetent's destitute second cousin based on evidence of prior gifts, though "not in large sums"); In re Calasantra, 154 Misc. 493, 494, 278 N.Y.S. 263, 265 (1935) (petition granted to incompetent's sister, mother of eight children, court relying upon evidence that sister had given spending money to incompetent when he was unemployed, and that when he entered army he offered to have his paycheck made over to her); In re Fleming, 173 Misc. 851, 19 N.Y.S.2d 234 (1940) (petition granted to adult niece of incompetent who was in poor health, based on finding of incompetent's "deep affection" for her and prior habit of contributing generously to her support); In re Bond, 98 N.Y.S.2d 81 (1950) (petition granted to sister of incompetent for support of herself and her brother, who was bedridden with arthritis; court focused on incompetent's prior "deep interest" in his invalid brother, other history of family relationships, and fact that he had sent his army pay home to his brother).

But see In re Johnson, 111 N.J. Eq. 268, 162 A. 96 (1932) (petition denied to nephew and niece of incompetent's "half blood" who were apparent next of kin, where incompetent had executed will bequeathing all property to two other persons); In re Schley, 201 Misc. 522, 107 N.Y.S.2d 884, aff'd, 113 N.Y.S.2d 448 (1951). In the latter case, the daughter-in-law of the incompetent petitioned for one-third of his surplus income for support and maintenance of herself and her 15-year-old son. Her request was denied because there was no evidence she had ever met the incompetent, nor evidence of true financial need, nor did she qualify as a member of the incompetent's "family" within the meaning of the Civil Practice Act. However, the petition was granted for the grandson, where the "close blood relationship existing between the two seems sufficient to counteract such lack of knowledge" and the grandson was "a person reasonably to be included within the word "family." " Id. at 528, 107 N.Y.S.2d at 890 . Being "family" can have its advantages. The grandson, burdened with the name Sturges Belsterling Schley, also stood to inherit over a million dollars if he survived his incompetent grandfather. Some burdens are easier to bear than others. 
answers to justify granting the petitions. ${ }^{159}$ In almost all cases, Lord Eldon's legal fiction was used, with or without attribution. In almost all cases, the evidentiary constraints were imposed. The focus was almost always on the incompetent and the manifestations of his former intent.

There was one anomalous decision, however, that departed from the accepted use of Lord Eldon's legal fiction. ${ }^{160}$ The facts in Sheneman v. Manring were unusually sad; they hinted at an underlying personal tragedy that was not revealed in the recorded decision. Mr. Antone Dautschmann had recently been adjudged incompetent. He was eighty-eight years old and blind, a widower who had lived alone for years with the assistance of a housekeeper. His estate was worth approximately $\$ 45,000$. All of Mr. Dautschmann's five children had died before him except for one daughter, Mrs. Susie Manring, who was forty-seven years old and in poor health. She was also poverty-stricken and living on public assistance. In 1939, Mrs. Manring petitioned the probate court to order her father's guardian to contribute fifty dollars a month for her support. Five years before, Mr. Dautschmann and his daughter had had a serious falling out. At that time, Mr. Dautschmann refused to give her any money; nor would he allow his daughter to live in his home. The Supreme Court of Kansas characterized these "bare fact[s] without explanatory circumstances" as "not very important." 161 The court then bid the guardian to take the following approach:

We can give no countenance to the suggestion that if the father had a personal hostility to his daughter in 1934 , it would be the duty of the guardian to continue that hostility towards her in 1939 ! What a normal father ought to do and probably would do under the circumstances is the proper attitude for the father's guardian to take when the infirmities of age will not permit the father to act for himself. ${ }^{162}$

Sheneman v. Manring represented a return to Lord Eldon's legal fiction as it had first appeared in Whitbread, unencumbered by evidentiary constraints. In the search for probable donative intent, the court left the dark cave of

159. The Supreme Court of Tennessee, for example, relied on Shelford's account of the sign manual and its limited powers of administration to hold that the equity court had no jurisdiction to grant a petition for an allowance to an incompetent's mother and two minor nieces. See Lewis v. Moody, 149 Tenn. 687 , 261 S.W. 673 (1924). The Tennessee legislature responded several years later by enacting a statute that gave equity courts the power to make such allowances under certain circumstances. See Monds v. Dugger, 176 Tenn. 550, 144 S.W.2d 761 (1940) (upholding statute's constitutionality); see also In re Brice's Guardianship, 8 N.W.2d 576 (Towa 1943) (relying on guardian's statutory authority for "management of the ward's affairs" to grant allowance; decision characterized by dissent as "judicial legislation"); Dewald v. Morris, 397 S.W.2d 738 (Mo. App. 1965) (finding probate court has authority under statute to award payment to incompetent's niece-in-law upon showing that "incompetent, if he were sane, would himself make the contribution."). But see Kelly v. Scott, 215 Md. 530, 537, 137 A.2d 704, 708 (1958) (finding no statutory authority for courts to make such allowances because state has duty to keep incompetent's property without waste and destruction; concluding "that is a problem for the Legislature").

160. Sheneman v. Manring, 107 P.2d 741 (Kan. 1940).

161. Id. at 743 .

162. Id. at $743-44$. 
Mr. Dautschmann's mind and asked not what the world might have looked like from his point of view, but what the world should look like from the point of view of a "normal father." The generic, reasonable lunatic replaced Mr. Dautschmann, and the court gave up worrying about what one embittered, blind old man would do.

Should we lose any sleep over a decision rendered by the Supreme Court of Kansas nearly half a century ago? Dispensing with Mr. Dautschmann's point of view is hardly the sort of stuff that insomnia is made of. Sheneman $v$. Manring was an anomaly, a unique departure from the way Lord Eldon's legal fiction had come to be applied. No other court before or after the Supreme Court of Kansas in 1940 has advocated leaving the evidentiary constraints behind, and certainly Mrs. Manring needed the money. No one could quarrel with that.

But something happened to Lord Eldon's legal fiction that made the maneuver in Sheneman v. Manring worth worrying about. It was borrowed. ${ }^{163}$ Now there is nothing inherently worrisome about borrowing a bit of law. It happens all the time. A new situation will arise that the existing set of legal categories, rules, and principles is ill equipped to handle. While a rational response to a new situation might be to create some new law, lawyers are by nature conservative. We do not like too much newness. It is bad enough dealing with a new situation; it only compounds our anxiety to have to contemplate a new body of law. So we borrow some old law from analogous situations. But borrowing old law does not always work that well. Sometimes the borrowed conceptual apparatus proves to be an inadequate, rickety structure that cannot support the weight of the new situation. Thus we find judges sitting at their desks, bending the old law this way and that, adding flying buttresses to make it stronger and removing vestigial remnants that no longer apply. This process may create a new body of law that is clumsy, inaccessible, and aesthetically unappealing, but that is the price we have to pay. And we do pay that price all the time, ungrudgingly and with little sense of worry. Borrowing bits of law is an accepted part of the judicial repertoire. ${ }^{164}$

163. It should be noted that Lord Eldon's legal fiction was also transplanted to the area of tax law. It was employed to make gifts from incompetents' estates in order to avoid estate taxes or to make gifts to family members or charitable institutions in order to reduce income taxes. See City Bank Farmers Trust Co. v. McGowan, 323 U.S. 594 (1945); In re Wemyss, 20 Cal. App. 3d 877, 98 Cal. Rptr. 85 (1971); In re Guardianship of Christiansen, 248 Cal. App. 2d 398, 56 Cal. Rptr. 505 (1967); In re DuPont, 41 Del. Ch. 300, 194 A.2d 309 (1963); Strange v. Powers, 358 Mass. 126, 260 N.E.2d 704 (1970); In re Turner, 305 N.Y.S.2d 387 (1969). In these tax reduction cases, an objective standard was often expressly applied, on the rationale that all incompetents would intend to favor their families over the government as the beneficiaries of their largess. See, e.g., Christiansen, $248 \mathrm{Cal}$. App. 2d at 423, $56 \mathrm{Cal}$. Rptr. at 522.

164. These thoughts crystallized during a conversation I had in 1988 at Pike Lake State Park with Linda Garcia of the Office of Technology Assessment. Ms. Garcia was the Project Director of an OTA project that evaluated the impact of new communication technologies for the House Committee on Energy and Commerce. She questioned why lawyers always try to use old categories of thought to solve problems that are generated by new technologies. The project report is fascinating. OFFICE OF TECHNOLOGY ASSESSMENT, U.S. CONGRESS, CRITICAL CONNECTIONS: COMMUNICATION FOR THE FUTURE (1990). 
Perhaps because we are so accustomed to this process of borrowing, no one seemed to notice when Lord Eldon's legal fiction was lifted from the law of lunacy, or that Lord Eldon's legal fiction had been borrowed for all the wrong reasons. It was not that there was no existing law to cover a new situation. The situation was not all that new; the borrower just did not like the result that the existing law reached upon its application. Nor did making allowances out of the lunatic's surplus income present a particularly analogous situation. Whitbread was about a lunatic and his money. Strunk was about an idiot and his body. The situations were not all that similar.

But I anticipate. Here is what happened. Sometime in the late 1960's, somewhere in Kentucky, a woman named Ava Strunk filed a petition with a county court. ${ }^{165}$ Mrs. Strunk was petitioning on behalf of her twenty-seven-year-old son, Jerry Strunk, an incompetent. He had an I.Q. of approximately thirty-five, which corresponded roughly to a mental age of six years. He also had a speech defect that made it difficult for him to communicate. Jerry Strunk lived in a state hospital, an "institution maintained for the feebleminded." 166 There was no evidence that he had any surplus income. But Jerry Strunk had something besides money that someone else desperately needed. He had a surplus kidney.

Tommy Strunk was Jerry Strunk's older brother. He was twenty-eight years old, an employee of the railroad and a part-time student at the University of Cincinnati. He was also dying of kidney disease. Tommy Strunk's time on dialysis seemed to be running out; the court characterized the treatment as "a procedure which cannot be continued much longer."167 Tommy Strunk was at death's door. This dire situation gave rise to an urgent need for a kidney to graft onto Tommy Strunk's body. Tommy's mother and father were tested for compatibility of blood and tissue type, as were a number of collateral relatives, but none of the prospective donors proved to be medically acceptable. Then, "[a]s a last resort," Jerry Strunk was tested, and lo and behold, he was found to be "highly acceptable."168 The mother of the two young men petitioned the county court for authority to "proceed with the operation."169

The county court, exercising its equitable jurisdiction over Jerry Strunk, granted the mother's petition and authorized the removal of his kidney. The county court's justification was based on a rather strained application of the "best interests" test. ${ }^{170}$ Under this test, the court assumes the responsibility

165. Strunk v. Strunk, 445 S.W.2d 145 (Ky. 1969).

166. Id. at 146.

167. Id. at 145.

168. Id. at 146 .

169. Id.

170. The term "best interests" probably comes from the "best interests of the child" standard which is currently applied in the law of child custody. Common law doctrine dictated that the father, as the natural guardian, had the legal right to the custody of his children. $1 \mathrm{~W}$. BLACKSTONE, COMMENTARIES *449; see also DeManneville v. DeManneville, 32 Eng. Rep. 762 (Ch. 1804). In this country, there was a move away from paternal rights with the development of the "tender years" doctrine that weighted custody disputes of small children in favor of the mother. By the mid-19th century, judges were exercising their discretionary 
for making the decision because the incompetent cannot. The guiding principle is that of beneficence. The court asks from an objective point of view what course of action will confer upon the incompetent the greatest net benefit. The best interests test focuses not on the desires of the incompetent, but on his interests as seen from an external point of view. Regarding Jerry Strunk, the county court held that:

under the peculiar circumstances of this case it would not only be beneficial to Tommy but also beneficial to Jerry because Jerry was greatly dependent upon Tommy, emotionally and psychologically, and that his well-being would be jeopardized more severely by the loss of his brother than by the removal of a kidney. ${ }^{171}$

Appeal was taken to the circuit court where the Chancellor adopted the findings of the county court. The Court of Appeals of Kentucky affirmed, holding that the court of equity had the power to permit a kidney to be removed from an incompetent ward of the state for transplantation into the body of his dying brother. ${ }^{172}$

How did the Court of Appeals of Kentucky accomplish this result? By adopting the county court's approach of manipulating the best-interests-of-theincompetent test. The court downplayed the intrusiveness of the medical procedure. Renal transplants were referred to as "the most common of the organ transplants"; a normal body had two kidneys, "one of which it can reasonably do without." 173 The transplant could also be performed "with minimal dan-

powers to settle custody disputes. One writer suggested that the codification of the best interests standard in New York in 1836 served to mandate the rejection of the paternal rights doctrine. See Stiles, NineteenthCentury Child Custody Reform: Maternal Authority and the Development of the "Best Interests of the Child" Standard, 6 PROB. L.J. 5 (1984). For a thorough discussion of the Chancellor's parallel jurisdiction over infants and idiots, see Cogan, Juvenile Law, Before and After the Entrance of Parens Patriae, 22 S.C.L. REV. 147, 155-61 (1970).

While the term "best interests" probably comes from the 19th century law of child custody, there are late 18 th century English decisions in which the Chancellor adhered to the principle of acting "for the benefit of the lunatic." Ex parte Grimstone, Amb. 706, 27 Eng. Rep. 458 (Ch. 1772) ("In the management of the lunatic's estate, the ruling principle is, to do what is for the benefit of the lunatic."); Oxendon v. Lord Compton, 2 Ves. Jun. 69, 30 Eng. Rep. 527 (Ch. 1793); In re Ashley, 1 Russ. \& M. 371, 39 Eng. Rep. 144 (Ch. 1830). The source of the principle in these earlier cases is invariably Prerogativa Regis. In this century, it is more common to see writers cite the doctrine of parens patriae as the source of the best interests of the incompetent test. See, e.g., Buchanan, The Limits of Proxy Decisionmaking For Incompetents, 29 UCLA L. REV. 386, 390 (1981); Minow, Beyond State Intervention in the Family, 18 U. MICH. J.L. REF. 933, 973 (1985).

171. Strunk v. Strunk, 445 S.W.2d 145, 146 (Ky. 1969).

172. The Kentucky Court of Appeals had no case law directly on point to cite as authority in Strunk. There were no reported decisions that dealt with the issue of whether an equity court had the power to authorize a nephrectomy on a mentally retarded incompetent who lacked the capacity to consent. The court in Strunk did cite a law review article: Curran, A Problem of Consent: Kidney Transplantation in Minors, 34 N.Y.U.L. REV. 891 (1959). However, the court did not mention the three decisions made in 1957 by the Supreme Judicial Court of Massachusetts in which the court authorized nephrectomies from minor twins for transplantation into their ailing siblings. See infra note 178.

173. Strunk, 445 S.W.2d at 148. 
ger" to both the donor and the donee. ${ }^{174}$ The low risk of the unilateral nephrectomy was balanced against the benefit that would inure to Jerry Strunk should his brother remain alive. Tommy Strunk was referred to as Jerry's "model, his tie with his family." 175 Without Tommy's frequent visits, Jerry would have lost his one intimate contact, his one emotional link to the outside world.

How had Lord Eldon's legal fiction made its way into a case about Jerry Strunk's kidney? What role did it play in the Strunk decision? Whitbread was cited as the leading case for the "doctrine of substituted judgment," Lord Eldon's legal fiction in its twentieth-century guise. ${ }^{176}$ The court in Strunk quoted from a recent $A . L . R$. that presented the doctrine of substituted judgment in the context in which it had always been applied: making allowances from a lunatic's surplus income. Then in one sweeping statement, the court took the doctrine of substituted judgment and expanded its application to any matter that concerned the "well-being" of the incompetent:

The right to act for the incompetent in all cases has become recognized in this country as the doctrine of substituted judgment and is broad enough to cover not only property but also all matters touching on the well-being of the ward. The doctrine has been recognized in American courts since 1844.177

The date 1844 was the year in which Willoughby was decided, the year in which Lord Eldon's legal fiction made its journey across the Atlantic. Whitbread and Willoughby were both decisions about making allowances or

174. Id.

175. Id. at 146.

176. The term "substituted judgment" was first directly linked to Lord Eldon's legal fiction in the American Law Reports. The A.L.R. read:

The "doctrine of substituted judgment," which apparently found its first expression in the leading English case of Ex parte Whitbread (1816) 2 Meriv 99, 35 Eng Reprint 878 (Ch), supra $\S 3(a)$, was amplified in Re Earl of Carysfort (1840) Craig \& Ph 76, 41 Eng Reprint 418, where the principle was made to apply to one who was not next of kin of the lunatic but a servant of his who was obliged to retire from his service by reason of age and infirmity. The Lord Chancellor permitted the allowance of an annuity out of the income of the estate of the lunatic earl as a retiring pension to the latter's aged personal servant, although no supporting evidence could be found, the court being "satisfied that the Earl of Carysfort would have approved if he had been capable of acting himself." Annotation, 24 A.L.R.3D 863, 899 (1969) (citations omitted).

Neither Whitbread nor Carysfort used the term "substituted judgment." In fact, none of the English cases in which Lord Eldon's legal fiction appeared called it "substituted judgment." In the context of a decision about making gifts from an incompetent's estate, the term "substituted judgment" was first used in In re Guardianship of Christiansen, 248 Cal. App. 2d 398, 407, 56 Cal. Rptr. 505, 511 (1967). The term had been used in numerous different contexts, however, most of them procedural. For example, a trial court might make a "substituted judgment . . . as to what verdicts should have been, for that of the jury." Esposito v. Henderson, $185 \mathrm{~Pa}$. Super. 479, 485, 137 A.2d 900, 902 (1958). The term had also been used for a court's subsequent judgment after its original judgment had been amended. See, e.g., Sexton v. Commonwealth, 252 S.W.2d 415, 415 (Ky. 1952); Pattison v. Henson, 240 S.W.2d 619, 620 (Ky. 1951).

177. Strunk v. Strunk, 445 S.W.2d 145, 148 (Ky. 1969). 
gifts from the lunatic's surplus income. Indeed, every decision that used Lord Eldon's legal fiction thereafter was about making allowances or gifts from the lunatic's surplus income. Never, in England or in any American jurisdiction, in this century or in the last, had the doctrine of substituted judgment been used for anything other than making allowances or gifts from the lunatic's surplus income. The Court of Appeals of Kentucky had no basis whatsoever for its claim that Lord Eldon's legal fiction was broad enough "to cover all matters touching on the well-being of the ward."

Something else rather dramatic happened in the Strunk decision. Lord Eldon's legal fiction was lifted from the law of lunacy and introduced into a decision about an idiot. Jerry Strunk was mentally retarded. He never had any former intentional states to refer to, nor did he have any hope for a lucid interval in the future. Because he had always lacked the capacity to make gifts, there could be no prior acts of gift-making from which to draw an inference of probable donative intent. Indeed, none of the factors courts had come to look for and insist upon could be found in Jerry Strunk's history. The evidentiary constraints imposed upon Lord Eldon's legal fiction became totally useless when applied to an idiot; they only made sense for a lunatic. This meant that with respect to someone like Jerry Strunk, the judge could have unfettered discretion in making the substituted judgment. If the test were to do that which it is probable the idiot himself would have done, the judge would be as free as Lord Eldon had been in Whitbread when he entered Mr. Hinde's mind; as free as the Supreme Court of Kansas had been when it dispensed with Mr. Dautschmann's point of view; as free as the judge needed to be to find what he was looking for: a generic, reasonable idiot prone to giving his organs away.

The doctrine of substituted judgment did not really take a firm hold in subsequent organ transplant cases. ${ }^{178}$ The next time the doctrine surfaced was

178. Subsequent organ transplant cases did not always concern mentally ill or retarded "donors." Some of them dealt with the transplantation of vital organs from one minor sibling to another. Only one court expressly relied upon the doctrine of substituted judgment to authorize a nephrectomy on a seven-year-old girl for transplantation into her twin sister. Hart v. Brown, 29 Conn. Supp. 368, 289 A.2d 386 (Super. Ct. 1972). The court in Hart v. Brown relied on Strunk and three Massachusetts decisions authorizing nephrectomies from minor twins for transplantation into their ailing siblings. Foster v. Harrison, No. 68674 Eq. (Mass. Nov. 20, 1957); Huskey v. Harrison, No. 68666 Eq. (Mass. Aug. 30, 1957); Masden v. Harrison, No. 68651 Eq. (Mass. June 12, 1957). The court also cited Bonner v. Moran, 126 F.2d 121, 123 (D.C. Cir. 1941), which held that parental consent for a skin graft from a 15-year-old boy was necessary. From the holding in Bonner, the court in Hart found authority for the proposition that nontherapeutic operations could be legally permitted on a minor as long as the parent or guarcian gave consent. Hart v. Brown, 29 Conn. Supp. at 375, 289 A.2d at 390. The Hart court erroneously concluded that Strunk and the Massachusetts cases had been decided by applying substituted judgment, and authorized the surgery on the minor twin "using the doctrines of law as stated in the Strunk case, in the Bonner case, and in the Massachusetts cases." Id. at 377,289 A.2d at 391.

Hart v. Brown was the only decision to use substituted judgment to authorize an organ transplant from a donor incapable of giving consent. Other decisions authorized such surgeries, but used different doctrines as the basis for the authorization. See In re Doe, 104 A.D.2d 200, 481 N.Y.S.2d 932 (1984) (authorizing removal of bone marrow from mentally retarded man for transplantation into his brother under best interests of the incompetent test); Little v. Little, 576 S.W.2d 493, 497-500 (Tex. Civ. App. 1979) (authorizing nephrectomy on mentally retarded 14-year-old girl for transplantation into her younger brother under best 
in the case of Karen Quinlan. The media so imprinted the sad plight of Karen Quinlan on our collective psyche that her story has become part of the nation's mythology. ${ }^{179}$ Her father, Joseph Quinlan, sought to be appointed guardian of his tragically brain-damaged daughter. He also sought the authority to terminate the respirator that kept her alive. It was in the lower court Quinlan decision that the doctrine of substituted judgment made its awkward entry into the termination of life support cases. Part of Joseph Quinlan's argument was that "under the equitable doctrine of substituted judgment this court can act in Karen Quinlan's best interest by authorizing the cessation of the respirator."180 This was not Lord Eldon's legal fiction of "doing that which it is probable the incompetent himself would have done," but the best interests test with the wrong label attached to it. Later the lower court referred to the doctrine of substituted judgment as "[t]he power to act for an incompetent in the affairs of his estate and person,"181 citing Strunk and Hart v. Brown as "persuasive in favor of the existence of the authority of this court to aid and protect Karen Quinlan and act in her best interests."182 Once again, the lower court did not apply Lord Eldon's legal fiction; rather, it just made a general statement about its expanded parens patriae power and the court's duty to look after the best

interests of the incompetent test).

Two other courts held that the equity court lacked the power to authorize a nephrectomy on an incompetent for transplantation into a sibling donee. In re Richardson, 284 So. 2d 185, 187 (La. App. 1973) ("Since our law affords this unqualified protection against [giving away a minor's property], it is inconceivable to us that it affords less protection to a minor's right to be free in his person from bodily intrusion to the extent of loss of an organ unless such loss be in the best interest of the minor."); In re Guardianship of Pescinski, 67 Wis. 2d 4, 226 N.W.2d 180 (1975). In Pescinski the Supreme Court of Wisconsin expressly rejected substituted judgment and used the best interests test to authorize a kidney transplant from a 39-yearold mentally ill brother who was institutionalized in a state hospital. The dissent in Pescinski argued that the equity court should have used substituted judgment and authorized the nephrectomy. The best interests test would "forever condemn the incompetent to be always a receiver, a taker, but never a giver. . . [H]e is forever excluded from doing the decent thing, the charitable thing." Id. at 12, 226 N.W.2d at 184. By applying substituted judgment, the equity court would "endow[] him with the finest qualities of his humanity, [assume] the goodness of his nature instead of assuming the opposite." Id. Lurking behind the scenes in Pescinski was another brother, Ralph Pescinski, who might have been a suitable donor, but who, for family and health reasons, failed to consent to a nephrectomy. His doctor "told him he should not get involved and that his family should come first." Id. at 7, 226 N.W.2d at 181. There was no hint of dishonor in the court's description of Ralph Pescinski's decision not to donate his kidney. One has to wonder if the dissent in Pescinski would have said that Ralph Pescinski had excluded himself from doing the decent thing, the charitable thing, that he was not endowed with the finest quality of his humanity.

179. Karen Quinlan was one of three children of Joseph and Julia Quinlan. When Karen was 21 years old, due to circumstances that will forever remain a mystery, she suffered two 15 -minute periods of interrupted respiration. This resulted in irreversible brain damage. Since she was not brain dead according to the Ad Hoc Committee of Harvard Medical School Criteria, Karen was described as being in a "persistent vegetative state," and could not maintain her vital processes without the assistance of a respirator. Karen's family was in agreement, along with their parish priest, that she should be removed from the respirator. Her doctor refused, and Joseph Quinlan petitioned the court to appoint him as guardian of the person and property of his daughter. He also proposed that the letters of guardianship, if granted, should contain an express power to him to authorize the discontinuation of all extraordinary medical procedures. In re Quinlan,

137 N.J. Super. 227, 348 A.2d 801 (1975).

180. Id. at $251,348 \mathrm{~A} .2 \mathrm{~d}$ at 814 .

181. Id. at $254,348 \mathrm{~A} .2 \mathrm{~d}$ at 816 .

182. Id. at $255,348 \mathrm{~A} .2 \mathrm{~d}$ at 816 . 
interests' of the incompetent. Then several pages later, with no fanfare, the lower court blurted out Lord Eldon's legal fiction: "The assertion that Karen would elect, if competent, to terminate the respirator requires careful examination." 183

The lower court in Quinlan proceeded to make that careful examination, imposing evidentiary constraints not unlike those imposed upon Lord Eldon's legal fiction in its original application: What had Karen said to others about termination of life-support systems? How serious and frequent were those conversations? Was it possible for the court to pretend that Karen had made "a decision," given "the vigor of youth that espouses the theoretical good and righteousness, the absence of being presented the question as it applied to her"? 184

Both the lower court in Quinlan and the Supreme Court of New Jersey agreed that there was insufficient "evidence of what she would want done in such a contingency as now exists." 185 But after concluding that it could not apply Lord Eldon's legal fiction to Karen Quinlan's situation, the Supreme Court of New Jersey did an about-face. It reasoned that Karen's "putative decision" to terminate her noncognitive, vegetative existence was incidental to her right of privacy. The only way to "prevent destruction of the right is to permit the guardian and family of Karen to render their best judgment, subject to the qualifications hereinafter stated, as to whether she would exercise it in these circumstances." ${ }^{186}$ Lord Eldon's legal fiction had finally made its entry into the law of informed consent.

The English common law would not have had a name for Karen Quinlan. Certainly she was not an idiot. While her condition was now static, she had not come into the world with a deficient mental apparatus; there was a past period

183. Id. at $259,348 \mathrm{~A} .2 \mathrm{~d}$ at 819 .

184. Id. at $260,348 \mathrm{~A} .2 \mathrm{~d}$ at 819 .

185. In re Quinlan, 70 N.J. 10, 21, 355 A.2d 647, 653 (1976).

The Attorney General had filed a cross-appeal challenging the trial court's admission into evidence of Karen Quinlan's prior statements about her distaste for continuance of life-support systems in circumstances not unlike her own. The challenge was based on the hearsav rule. Since the Supreme Court of New Jersey agreed with the lower court that the statements "were remote and impersonal, lacked significant probative weight," the court deemed it insignificant to its opinion whether the statements were admissable or not. Id. at $22,355 \mathrm{~A} .2 \mathrm{~d}$ at 653 .

186. Id. at 41,355 A.2d at 664 . The qualifications on the exercise of Karen's substituted judgment were as follows:

Upon the concurrence of the guardian and family of Karen, should the responsible attending physicians conclude that there is no reasonable possibility of Karen's ever emerging from her present comatose condition to a cognitive, sapient state and that the life-support apparatus now being administered to Karen should be discontinued, they shall consult with the hospital "Ethics Committee" or like body of the institution in which Karen is then hospitalized. If that consultative body agrees that there is no reasonable possibility of Karen's ever emerging from her present comatose condition to a cognitive, sapient state, the present life-support system may be withdrawn and said action shall be without any civil or criminal liability therefor on the part of any participant, whether guardian, physician, hospital or others.

Id. at 54, $355 \mathrm{~A} .2 \mathrm{~d}$ at 671 (footnote omitted). 
of competency to hark back to. But neither was she a lunatic. Although she had once been competent, there was no waxing and waning of her intellect. Indeed there was no longer any intellect at all. Karen Quinlan's deficit was more profound than the lunatic's. His was a failure of reason alone; hers was a failure of consciousness. The closest legal category that the common law had to describe her status was "decedent," but the persistence of her lower brain function and the presence of her warm body made her not dead-not dead, not alive, not an idiot, not a lunatic. There was a lacuna in the language of the law, so she was thrown into the general class of incompetents. There was no finetuning as to who was in that class-just individuals who were presently incompetent, regardless of how they came to be that way.

At least as far as the application of Lord Eldon's legal fiction, however, Karen Quinlan was more of a lunatic. The evidentiary constraints required a history of past competency to consult in order to determine what it is probable the incompetent patient would have done. Karen Quinlan had such a history; it turned out to be too thin to support a finding of probable intent, but she had a history just the same. If Lord Eldon's legal fiction was going to be borrowed in its entirety, complete with the evidentiary constraints, the Supreme Court of New Jersey should not have applied it to Karen Quinlan. With insufficient evidence of what she probably would have done, the substituted judgment should not have been made. Instead, the legal fiction took the form in Quinlan that it originally had taken in Whitbread, had assumed in Sheneman v. Manring, and was hinted at in Strunk. The evidentiary constraints were silently shed. ${ }^{187}$

187. Less than 10 years after Quinlan, the Supreme Court of New Jersey reinstated the evidentiary constraints imposed on Lord Eldon's legal fiction in its 20th-century guise. See In re Conroy, 98 N.J. 321, 486 A.2d 1209 (1985). The guardian and nephew of Claire Conroy sought permission to remove a nasogastric feeding tube from his incompetent aunt. Although Ms. Conroy was neither brain dead nor in a persistent vegetative state, she was severely demented and had no higher functioning or consciousness. The evidence as to whether, and to what extent, she was capable of experiencing pain was inconclusive. The trial court granted the guardian permission to remove the nasogastric tube, and the appellate court reversed. (Ms. Conroy had died while the appeal was pending. The nasogastric tube remained intact until her death.) See In re Conroy, 190 N.J. Super. 453, 464 A.2d 303 (1983), rev'd, 98 N.J. 321, 486 A.2d 1209 (1985).

After reaffirming the right of an incompetent to refuse medical treatment, the Supreme Court of New Jersey reiterated Lord Eldon's legal fiction: "Nevertheless, the gcal of decision-making for incompetent patients should be to determine and effectuate, insofar as possible, the decision that the patient would have made if competent." 98 N.J. at 360, 486 A.2d at 1229. The court emphasized the need for evidence of the patient's former intent, including living wills, oral directives, religious beliefs, and any other information bearing on what course of treatment the patient would have chosen. The court then stated that its earlier decision to disregard Karen Quinlan's comments to friends about artificial life support had been erroneous. The evidentiary constraints on the legal fiction were back. Where there was no "adequate proof of the patient's wishes," the court held that substituted judgment could not be used. Id. at 364, 486 A.2d at 1231 .

Thus substituted judgment for the mentally retarded or for the formerly competent patient who had never expressed his intent about life support was ultimately rejected in New Jersey. In its place, however, the court in Conroy fine-tuned the best interests of the incompetent test to include a "limited-objective" and a "pure-objective" test. The limited-objective test applied when there was some "trustworthy evidence that the patient would have refused the treatment, and the decisionmaker is satisfied that it is clear that the burdens of the patient's continued life with the treatment outweigh the benefits of that life for him." Id. at $365,486 \mathrm{~A} .2 \mathrm{~d}$ at 1232 . In the absence of trustworthy evidence, or any evidence at all as to intent, the 
In Massachusetts, it became more obvious that Lord Eldon's legal fiction had been freed from the shackles of the evidentiary constraints when it was applied to an idiot. Much like Jerry Strunk, there was no ambiguity about Joseph Saikewicz's common law classification. ${ }^{188}$ At the age of sixty-seven, he had an I.Q. of ten and a mental age of two years and eight months. He also was suffering from leukemia. The superintendent and the attorney from the state facility where Joseph Saikewicz had been institutionalized for almost fifty years petitioned the probate court for the appointment of a guardian. At the same time, they petitioned for the appointment of a guardian ad litem with the authority to make necessary decisions about Saikewicz's medical treatment. Once the guardian ad litem had been appointed, he filed a report recommending that "not treating Mr. Saikewicz would be in his best interests."189

The medically indicated course of treatment for leukemia was chemotherapy. This treatment would have involved the administration of drugs over several weeks; the side effects included risk of anemia and infection, severe nausea, bladder irritation, tingling in the extremities, and loss of hair. Remission of the leukemia was achieved in thirty to fifty percent of the cases; typically it only lasted between two and thirteen months, although longer periods of remission were possible. If the condition were left untreated, however, the disease would run its natural course and the patient inevitably would die. The guardian ad litem and all the doctors who testified agreed that most people who suffered from leukemia would elect to have the chemotherapy, despite the side effects, rather than allow the disease to run its natural course. In other words, most people would choose the treatment and the possibility of remission over certain death. ${ }^{190}$

How then could the alternative of certain death be considered in Joseph Saikewicz's best interests? Why would the guardian ad litem recommend that

pure-objective test would be applied, requiring the decisionmaker to weigh the benefits and burdens of treatment. The court held that the evidence at Ms. Conroy's trial was inadequate to satisfy the subjective test, the limited-objective test, or the pure-objective test. The judgment was reversed, but because Ms. Conroy had died, the matter was not remanded.

Two later New Jersey cases were consistent with Conroy. See In re Peter, 108 N.J. 365, 377, 529 A.2d 419,425 (1987) (finding evidence of patient's "desire not to be sustained in her present condition" where she had executed power of attorney to close friend and there were nine accounts of her disinclination to be kept alive on life-support system); In re Jobes, 108 N.J 394, 529 A.2d 434 (1989) (finding evidence of former intent "trustworthy" but not clear and convincing, and applying limited-objective test, leaving substituted judgment to family). The Jobes decision generated two concurring opinions and a dissent, which concentrated on the "[s]erious conceptual and practical difficulties" with substituted judgment. Id. at 433, 529 A.2d at 454 (Handler, J., concurring). Judge Handler urged his colleagues to "consider in greater depth the scope and application of an appropriate standard for determining right-to-die cases when decisions based on self-determination are unattainable or illusory." Id. at 437,529 A.2d at 456 . It is ironic that these expressions of judicial dissatisfaction with substituted judgment should come from the very court that originally borrowed it from the law of lunacy. Perhaps the days are numbered for the application of the doctrine of substituted judgment, at least in the state of New Jersey.

188. Superintendent of Belchertown v. Saikewicz, 373 Mass. 728, 370 N.E.2d 417 (1977).

189. Id. at 730,370 N.E.2d at 419.

190. Id. at 733,370 N.E.2d at 421. 
he not be administered chemotherapy? And how did the probate court and the Supreme Judicial Court of Massachusetts come to agree? Through the application of Lord Eldon's legal fiction. The idea came from the Quinlan decision. Just as in Quinlan, the court in Saikewicz took as its departure the extension of the right of privacy to the incompetent person. Inherent in that right of privacy was the right to refuse consent to intrusions of bodily integrity ${ }^{191}$ And with someone like Joseph Saikewicz, the preservation of that right "depended on its indirect exercise by one acting on behalf of the incompetent person." ${ }^{192}$ Enter the doctrine of substituted judgment. The court in Saikewicz

191. The Saikewicz decision is frequently cited for articulating the following state interests: "1) the preservation of life; 2) the protection of the interests of innocent third parties; 3 ) the prevention of suicide; and 4) maintaining the ethical integrity of the medical profession." Id. at 741, 370 N.E.2d at 425 . These interests were balanced against the individual's rights of privacy and autonomy to choose to refuse potentially life-prolonging medical treatment. Id. at 741-45, 370 N.E.2d at 425-27.

192. Id. at 748,370 N.E.2d at 429. It should be noted that the Saikewicz decision differed significantly from the Quinlan decision as to who should exercise the incompetent person's right of privacy and autonomy. The court in Saikewicz expressly rejected the New Jersey Supreme Court's approach of entrusting the decision to the patient's guardian, family, doctors, and a hospital ethics committee. Instead, the Supreme Judicial Court of Massachusetts opted for a judicial substituted judgment. See id. at 758-59, 370 N.E.2d at 434-35. The Supreme Judicial Court of Massachusetts reaffirmed its requirement that the exercise of substituted judgment be made with judicial approval in In re Spring, 380 Mass. 629, 639, 405 N.E.2d 115, 122 (1980). The court applied substituted judgment to terminate a senile man's life-sustaining dialysis, despite lack of evidence as to his former intent: "An expression of intent by the ward while competent was not essential." Id. at 640,405 N.E.2d at 122 . So much for the evidentiary constraints. The Spring decision came under attack for the court's manipulation of the doctrine of substituted judgment. See, e.g., J. ROBERTSON, THE RIGHTS OF THE CRITICALLY ILL 58 (1983); Annas, Quality of Life in the Courts: Earle Spring in Fantasyland, HASTINGS CENTER REP., Aug. 1980, at 9-10; Note, Substituted Judgment in Medical Decisionmaking for Incompetent Persons: In Re Storar, 1982 WIS. L. REV. 1173, 1194-96.

For other decisions holding that judicial approval was required for the exercise of substituted judgment to terminate life-support systems, see Severns v. Wilmington Medical Center, 421 A.2d 1334 (Del. 1980); In re PVW, 424 So. 2d 1015 (La. 1982); In re Storar, 52 N.Y.2d 363, 438 N.Y.S.2d 266, 420 N.E.2d 64 (1980); Leach v. Akron General Medical Center, 68 Ohio Misc. 1, 426 N.E.2d 809 (Com. Pl. 1980). But see Barber v. Superior Court of California, 147 Cal. App. 3d 1006, 195 Cal. Rptr. 484 (1983) (judicial approval not required for exercise of substituted judgment to terminate life-support systems); Foody v. Manchester Memorial Hosp., 40 Conn. Supp. 127, 482 A.2d 713 (1984) (same); In re L.H.R., 253 Ga. 439, 321 S.E.2d 716 (1984) (same); In re Conservatorship of Torres, 357 N.W.2d 332 (Minn. 1984) (same); In re Guardianship of Hamlin, 102 Wash. 2d 810, 689 P.2d 1372 (1984) (en banc) (same). For decisions holding that judicial approval was not required unless there was a dispute among interested parties, see Rasmussen v. Fleming, 154 Ariz. 200, 741 P.2d 674 (1987); Conservatorship of William Drabick, 200 Cal. App. 3d 185, 245 Cal. Rptr. 840 (1988); John F. Kennedy Memorial Hospital v. Bludworth, 452 So. 2d 921 (Fla. 1984).

The medical and legal communities also responded vociferously to the requirement set forth in Saikewicz that judicial approval was needed for the exercise of substituted judgment to terminate life-support systems. See Relman, The Saikewicz Decision: Judges As Physicians, 298 NEW ENG. J. MED. 508 (1978) ("This astonishing opinion can only be viewed as a resounding vote of 'no confidence' in the ability of physicians and families to act in the best interests of the incapable patient suffering from a terminal illness."); Relman, The Saikewicz Decision: A Medical Viewpoint, 4 AM. J.L. \& MED. 233 (1978). For an opposing view, see Baron, Medical Paternalism and the Rule of Law: A Reply to Dr. Relman, 4 AM. J.L. \& MED. 337 (1978); see also Annas, Reconciling Quinlan and Saikewicz: Decision Making for the Terminally Ill Incompetent, 4 AM. J.L. \& MED. 367 (1978) (arguing Quinlan and Saikewicz are compatible, but establish different criteria for different types of cases, Quinlan involving cases in which medical criterion concerning prognosis is appropriate, and Saikewicz establishing procedure for decisionmaking by courts where legal criterion of substituted judgment is appropriate); Buchanan, Medical Paternalism or Legal Imperialism: Not the Only Alternatives for Handling Saikewicz-type Cases, 5 AM. J.L. \& MED. 97, 112 (1979) (favoring presumption for incompetent's family as decisionmaker). 
used the following formulation:

In short, the decision in cases such as this should be that which would be made by the incompetent person, if that person were competent, but taking into account the present and future incompetency of the individual as one of the factors which would necessarily enter into the decisionmaking process of the competent person. ${ }^{193}$

The probate court identified six factors that weighed against the chemotherapy: Joseph Saikewicz's age; the side effects; the "low chance" of producing remission; the certainty that the treatment would produce suffering; his inability to cooperate with the treatment; and "the quality of life possible for him even if the treatment does bring about remission." 194 Weighing in favor of the chemotherapy was the slight chance of producing remission and "the fact that most people in his situation when given a chance to do so elect to take the gamble of treatment." 195 When the probate court entered the mind of Joseph Saikewicz, it found a man who could not comprehend the reasons for the disruption of his secure and stable environment, who would experience only fear from the chemotherapy without understanding its possible benefits, who would become disoriented and confused from the side effects, who would feel pain from the slow intravenous administration of the drugs, and who would choose certain death over the treatment and the attendant possibility of remission. Finally Lord Eldon's legal fiction had hit the jackpot: here was a generic, reasonable idiot prone to giving his life away. ${ }^{196}$

193. Superintendent of Belchertown v. Saikewicz, 373 Mass. 728, 752-53, 370 N.E.2d 417, 431 (1977).

194. Id. at 735,370 N.E.2d at 422.

195. Id.

196. And indeed Joseph Saikewicz did die of bronchial pneumonia, a complication of the leukemia, just two months after the court's order that no chemotherapy therapy be administered.

After Saikewicz, the Supreme Judicial Court of Massachusetts next discussed substituted judgment in Custody of a Minor, 375 Mass. 733, 379 N.E.2d 1053 (1978). The court ordered that medication be administered to a two-year-old child suffering from leukemia, applying the best interests of the child test but finding it consistent with the substituted judgment doctrine because "the criteria to be examined and the basic applicable reasoning are the same." Id. at 753, 379 N.E.2d at 1065; see also Custody of a Minor, 385 Mass. 697, 434 N.E.2d 601 (1982) (applying substituted judgment to uphold "no code" order on chart of infant with terminal disease).

After Saikewicz, the two termination of life support cases in Massachusetts that applied substituted judgment were both about the removal of feeding tubes. See In re Hier, 18 Mass. App. 200, 208-09, 464 N.E.2d 959, 964-65 (1984) (applying substituted judgment to affirm order denying guardian authority to consent to insertion of feeding tube, where mentally ill patient had repeatedly removed feeding tube); Brophy v. New England Sinai Hosp., 398 Mass. 417, 497 N.E.2d 626 (1986) (authorizing guardian to take patient from hospital refusing to remove feeding tube and to place him in care of physicians who would honor his wishes).

Since the Saikewicz decision, the Supreme Judicial Court of Massachusetts had changed its tune. The trial court in Brophy based its substituted judgment on several factors, including Brophy's expressed preferences and religious convictions, that could never have been applied to a profoundly mentally retarded patient like Joseph Saikewicz. The Supreme Judicial Court of Massachusetts agreed with the trial court that there was sufficient evidence to support a finding as to Brophy's subjective viewpoint. Brophy, 398 Mass. at 433,497 N.E.2d at 635 . This discussion of Brophy's former point of view suggests that the evidentiary constraints imposed on Lord Eldon's legal fiction have worked their way into the Massachusetts common 
A few years later, in a neighboring jurisdiction, another profoundly mentally retarded person became terminally ill. John Storar, a fifty-two-year-old man with a mental age of about eighteen months, had cancer of the bladder. ${ }^{197} \mathrm{He}$ had been institutionalized in a state facility since the age of five, although he had maintained a close relationship with his seventy-seven-year-old mother who visited him almost daily. His mother had been appointed guardian, and with her consent, Storar had received radiation treatment. Eventually Storar's bladder developed lesions, and he began to lose blood continuously, necessitating transfusions every eight to fifteen days. These transfusions were not pleasant for Storar. The resulting blood clots in his urine upset him, and he displayed some initial resistance. However, there was also evidence that he perked up considerably after the transfusions and would resume his daily activities. ${ }^{198}$ By this time, Storar's cancer had spread to his lungs, and his life span was estimated to be between three and six months.

After several weeks of blood transfusions, his mother requested that they be discontinued. The director of the state facility petitioned the New York Supreme Court for authority to continue the transfusions. By cross-motion, Mrs. Storar sought a court order terminating the transfusions. Based on an application of both the best interests of the incompetent test and the doctrine of substituted judgment, her cross-motion was granted, and the Storar case began its climb up the appellate ladder. ${ }^{199}$

At the same time, in another part of New York State, a case with a similar constellation of facts was being litigated. ${ }^{200}$ Brother Fox was an eighty-threeyear-old member of the Order of the Society of Mary. One day while moving

Iaw too.

There were three justices in Brophy who filed dissenting or concurring opinions. One accused his colleagues of endorsing "euthanasia and suicide." Id. at 442, 497 N.E.2d at 640 (Nolan, J., dissenting). Another argued that the court had failed to give adequate weight to the state's interest in preserving life. Id. at 44344,497 N.E.2d at 640-41 (Lynch, J., dissenting in part). Two justices emphasized the lack of evidence that Brophy "knew the horrors of such a death" and would have wanted the tube removed. Id. at 442,497 N.E.2d at 640 (Nolan, J., dissenting); see also id. at 449, 497 N.E.2d at 644 (O'Connor, J., concurring in part and dissenting in part). These concerns over insufficient evidence of Brophy's former intent confirm my suspicion that the Supreme Court of Massachusetts has implicitly adopted the evidentiary constraints.

197. In re Storar, 106 Misc. 2d 880, 433 N.Y.S.2d 383 (1980).

198. Evidence of this resurgence of energy included such activities as "feeding himself, showering, taking walks and running -including some mischievous ones, such as stealing cigarette butts and attempting to eat them." In re Storar, 52 N.Y.2d 363, 374, 438 N.Y.S.2d 266, 271, 420 N.E.2d 64, 69 (1981).

199. At the Appellate Division level, Mrs. Storar also prevailed. See In re Storar, 78 A.D.2d 1013, 434 N.Y.S.2d 46 (1980). Substituted judgment was not expressly applied, but the Appellate Division held the court must enforce Storar's right to decline medical treatment on the request of his mother, citing Saikewicz, Quinlan, and the Appellate Division decision in In re Eichner, 73 A.D.2d 431, 426 N.Y.S.2d 517 (1980).

There was a scathing dissent by Judge Cardamone. He characterized substituted judgment as "Orwellian." To argue that the court was authorizing the discontinuation of transfusions as an exercise of Storar's rights was "legal nonsense": "To deprive a human of life, no matter how burdened it may be, is to deny that person of any and all rights." Storar, 78 A.D.2d at 1014, 434 N.Y.S.2d at 47 (Cardamone, J., dissenting).

200. In re Eichner, 102 Misc. 2d 184, 423 N.Y.S.2d 580 (1979). 
some flower tubs on a roof garden, Brother Fox suffered a hernia. During surgery to repair the hernia, he had a cardiac arrest, suffered irreversible brain damage, and was put on a respirator that maintained him in a persistent vegetative state. Father Eichner, who was an old friend and a leader of the religious community, petitioned the Court to be appointed Brother Fox's guardian with the authority to remove the respirator. Because of the Quinlan decision and a 1959 allocution by Pope Pius XII about extraordinary means of treatment, the religious community had publicly discussed at length the issue of termination of life-support systems. Brother Fox had been a frequent and vocal participant in these discussions. Not only had Brother Fox agreed with the Church's teachings, but he had also stated that "he personally would not want any of this 'extraordinary business' done for him under such circumstances."201 Father Eichner's petition was granted, and the Eichner case too began its climb up the appellate ladder. ${ }^{202}$

Eventually the Court of Appeals of New York joined the Storar and Eichner cases. $^{203}$ The previous order in Storar discontinuing blood transfusions was reversed, and the order in Eichner permitting termination of the respirator was upheld, although it was somewhat modified. The holdings of the two cases were different due to the court's recognition that Brother Fox was more like a Iunatic, while John Storar more closely resembled an idiot. The court did not use those words, but made the distinction in terms of evidence. With respect to the intent of Brother Fox to terminate the respirator, "the proof was compelling." ${ }^{204}$ The court went on to impose the usual evidentiary constraints from Lord Eldon's legal fiction. Brother Fox had repeatedly expressed his views in public settings about his desire not to have his life prolonged by medical means if there was no hope of recovery. He reiterated this view just two months before his final hospitalization, and it was held to be consistent with his religious beliefs and his "life of unselfish religious devotion." ${ }^{205}$ Unlike the statements of Karen Quinlan, "these were obviously solemn pronouncements and not casual remarks made at some social gathering, nor can it be said that he was too young to realize or feel the consequences of his statement."206 In

201. Id. at 192,423 N.Y.S.2d at 586.

202. At the Supreme Court, Special Term level, the petition was granted, but the court expressly rejected application of substituted judgment. Since Brother Fox had so clearly indicated that he would not consent to the continuation of the respirator, the court concluded:

If Father Eichner ... were to request the termination of the respirator, then that request would be the decision of Brother Fox which Father Eichner would merely pass on as a conduit. Unlike Quinlan or Saikewicz, no fiction is created nor is the judgment of Father Eichner substituted for that of Brother Fox.

Id. at 204, 423 N.Y.S.2d at 597. The Appellate Division affirmed, but based its opinion on the right of privacy and the doctrine of substituted judgment. See In re Eichner, 73 A.D.2d 431, 426 N.Y.S.2d 517 (1980).

203. In re Storar, 52 N.Y.2d 363, 438 N.Y.S.2d 266, 420 N.E.2d 64 (1981).

204. Id. at 379,438 N.Y.S.2d at 274,420 N.E.2d at 72.

205. Id. at 380,438 N.Y.S.2d at 274,420 N.E.2d at 72.

206. Id. 
short, Brother Fox's actions and statements met the court's articulated standard of "clear and convincing" evidence of his intent. Not so with John Storar. There was no proof of that nature; nor could there ever be:

John Storar was never competent at any time in his life. He was always totally incapable of understanding or making a reasoned decision about medical treatment. Thus it is unrealistic to attempt to determine whether he would want to continue potentially life prolonging treatment if he were competent. As one of the experts testified at the hearing, that would be similar to asking whether "if it snowed all summer would it then be winter?"207

The Supreme Judicial Court of Massachusetts and the New York Court of Appeals thus took radically different approaches to the application of the doctrine of substituted judgment. In Massachusetts, Lord Eldon's legal fiction was applied to Joseph Saikewicz with no evidence of his former intent. Indeed, because of his profound mental retardation, he could never have formed such intent. This was of no concern to the Massachusetts court, however, since it did not impose any evidentiary constraints upon the application of the legal fiction. In New York, the Court of Appeals was rather strict about the application of the doctrine of substituted judgment. The evidentiary constraints that had been imposed upon Lord Eldon's legal fiction for over a hundred years were adhered to with religious fervor. There was ample evidence that Brother Fox, if competent, would probably have decided to terminate the respirator. The New York court saw things differently with respect to John Storar, however.

207. Id. at 380,438 N.Y.S.2d at 274,420 N.E.2d at $72-73$.

The Court of Appeals of New York recently had an opportunity to reassess its view on substituted judgment. See In re Westchester County Medical Center, 72 N.Y.2d 517, 534 N.Y.S.2d 886, 531 N.E.2d 607 (1988). There the patient had suffered severe brain damage but was capable of responding to simple questions and requests. The hospital applied for judicial authorization to insert a nasogastric feeding tube over the objections of her daughters. The court found that the evidence was not "clear and convincing" that "the patient had made a firm and settled commitment, while competent, to decline this type of medical assistance under circumstances such as these." Id. at 522, 534 N.Y.S.2d at 887,531 N.E.2d at 608 . While both daughters and a friend testified that Mrs. O'Connor had said on several occasions that if she were very ill, she "would not want her life to be sustained artificially," id. at 527,534 N.Y.S.2d at 890,531 N.E.2d at 611, all three agreed that she had never discussed the withdrawal of food and water; nor had she said anything about declining treatment if that would produce a painful death. Id. In short, it could not be said what Mrs. O'Connor "would do, or what she would want done under these circumstances." Id. at 534, 534 N.Y.S.2d at 894,531 N.E.2d at 615 .

By insisting on such a high standard of proof of former intent, the Court of Appeals of New York remained doggedly faithful to the evidentiary constraints. In dissent, Judge Simons argued that the majority in Westchester County was too strict and narrow in its application of substituted judgment. He characterized the court's decision in Storar as "unfortunate," and recommended a broadening of the Eichner rule. Id. at 541, 534 N.Y.S.2d at 899, 531 N.E.2d at 620 (Simons, J., dissenting). Otherwise, patients like John Storar, or even someone like Karen Quinlan, who had never expressed her intent, would have "needless suffering" inflicted upon them; "simple decency require[d] that a remedy be found." Id.

New York has since passed legislation that sets up a decisionmaking process allowing competent adults to appoint an agent to make health care treatment decisions in the event they lose their capacity. Act of July 22, 1990, ch. 752, 1990 N.Y. Laws 752. 
Just like Joseph Saikewicz, there was not, and never could be, any evidence of John Storar's former intent. And without that evidence, the doctrine of substituted judgment would not be applied.

Until Cruzan v. Director, Missouri Department of Health, ${ }^{208}$ the doctrine of substituted judgment in termination of life support decisions belonged almost exclusively to the province of state courts. The victim of a car accident in 1983, Nancy Cruzan has since been maintained in a persistent vegetative state on a gastrostomy feeding and hydration tube. Once it became apparent that she was never going to regain her mental faculties, her parents asked the hospital to remove the tube. When the hospital refused, her parents sought authorization from a Missouri trial court to terminate the feeding and hydration. The trial court granted the authorization, relying on Nancy's "expressed thoughts at age twenty-five in somewhat serious conversation with a housemate friend that if sick or injured she would not wish to continue her life unless she could live at least halfway normally."209

The Supreme Court of Missouri reversed, holding that the state had an unqualified interest in the preservation of human life that must be weighed against any constitutionally protected interests of the individual. A strict standard of clear and convincing evidence was adopted to further that state interest. $^{210}$ No person could make the choice to terminate life-sustaining treatment for an incompetent patient in the absence of a living will or of clear and convincing evidence of the patient's former intent. Nancy Cruzan's statements to her housemate were considered " unreliable for the purpose of determining her intent . . . and thus insufficient to support the co-guardians claim to exercise substituted judgment on Nancy's behalf." "211 And so, according to the Supreme Court of Missouri, Nancy Cruzan must be kept alive.

The Supreme Court of the United States granted certiorari to consider whether Nancy Cruzan has a federal constitutional right to require the hospital to withdraw her life-sustaining treatment, and the doctrine of substituted judgment was at last given the opportunity to become a part of Supreme Court jurisprudence. Lord Eldon's legal fiction had finally made its way from the early nineteenth-century law of lunacy to the highest court in our land. In a five-to-four decision, the judgment of the Supreme Court of Missouri was affirmed. A state may apply a clear and convincing evidence standard in proceedings where a guardian seeks to discontinue nutrition and hydration of a person in a persistent yegetative state. ${ }^{212}$

208. 110 S. Ct. 2841 (1990).

209. Id. at 2846 .

210. Id.

211. Id. (quoting Cruzan v. Harmon, 760 S.W.2d 408, 424, 426 (Mo. 1988) (en banc)).

212. Id. at 2854 . 
Although the litigants used the term "substituted judgment" inconsistent$1 y,{ }^{213}$ Cruzan is a case about the evidentiary constraints imposed on the application of Lord ildon's legal fiction. Missouri, much like New York, requires formalized and very specific manifestations of the incompetent patient's former intent, and the Supreme Court has held that it is constitutionally permissible for a state to do so. The family's claim that even in the absence of evidence as to their daughter's wishes, the state should accept their "substituted judgment" on her behalf was rejected. The substituted judgment would only be allowed if it could be proved by clear and convincing evidence that it reflected the former intent of the patient. The evidentiary constraints have been imposed with a vengeance. And so, according to the Supreme Court of the United States as well, Nancy Cruzan must be kept alive.

Before Cruzan the doctrine of substituted judgment had been rapidly absorbed into the common law of many jurisdictions as a means of terminating life-support systems for incompetent patients. ${ }^{214}$ Paralleling this development

213. At one point in the decision, "substituted judgment" is used to mean situations in which the guardian is actually carrying out the patient's wishes, as evidenced by clear and convincing proof "of what the individual's decision would have been." Id. at 2855. Later, in a discussion of petitioner's argument that family members are in a better position to exercise the patient's "substituted judgment," even in the absence of proof of the incompetent's former intent, the term appears to mean instances in which the guardian did not know the incompetent's former intent. See id. at 2855-56. Thus, in Cruzan, the term substituted judgment seems to mean both decisions made by guardians based on clear and convincing evidence of the incompetent's former intent, and also decisions made by guardians based on no evidence of intent at all.

214. See Severns v. Wilmington Medical Center, 421 A.2d 1334, 1347 (Del. 1980) (chancery court "may recognize the right of a guardian of the person to vicariously assert the constitutional right of a comatose ward to accept medical care or to refuse it" following evidentiary hearing); $I n$ re Estate of Longeway, $133 \mathrm{Ill} .2 \mathrm{~d} 33,549$ N.E.2d 292 (1989) (adopting substituted judgment based on evidence of former intent or, in its absence, "patient's value system").

There was a whole line of decisions from the Supreme Court of Washington in which substituted judgment was used to decide whether life-prolonging treatment should be administered to incompetent patients. The seminal case was In re Colyer, 99 Wash. 2d 114,660 P.2d 738 (1983) (using term "substituted judgment" for instances in which court determines from evidence what treatment patient would have chosen, and finding such judicial determination necessary when patient has never been competent or when evidence of intent is uncertain); see also In re Guardianship of Grant, 109 Wash. 2d 545, 747 P.2d 445 (1987) (authorizing removal of life support from woman in "almost vegetative state" upon showing of intent based on personality, general attitude toward medical treatment, and prior statements); In re Guardianship of Ingram, 102 Wash. 2d 827, 689 P.2d 1363 (1984) (applying substituted judgment to reverse trial court's authorization of laryngectomy on 66-year-old woman who refused to consent to surgery, which required judicial approval under statute); In re Guardianship of Hamlin, 102 Wash. 2d 810, 689 P.2d 1372, 1378 (1984) (upholding removal of respirator from mentally retarded man and ruling that "the court need not always be involved in the actual substantive decision" for mentally retarded patients when physicians and guardian agree that ending treatment is in patient's "best interests").

In Rasmussen v. Fleming, 154 Ariz. 207, 741 P.2d 674 (1987), the Arizona Supreme Court found that the incompetent's guardian had implied statutory authority to refuse treatment for him, and ruled that substituted judgment may be applied where there is evidence of intent, but the best interests standard should otherwise be applied. It is not clear whether the doctrine of substituted judgment was adopted in Minnesota. In In re Conservatorship of Torres, 357 N.W.2d 332 (Minn. 1984), the Supreme Court of Minnesota expressly applied the best interests of the incompetent test, but then held that "the conservator had the right to issue his substituted judgment for that of the comatose conservatee." Id. at 341. Where there was agreement between the attending doctor and the family, and the approval of the hospital ethics committee, a court order would not be required. Id. at $341 \mathrm{n} .4$. The doctrine of substituted judgment made a brief appearance in Maine, but the Supreme Judicial Court of Maine chose not to adopt it. See In re Joseph v. 
was the use of Lord Eldon's legal fiction by courts to authorize the sterilization of incompetent young women. The doctrine of substituted judgment was first used in this context by the Superior Court of New Jersey, Chancery Division, in In re Grady. ${ }^{215}$ Lee Ann Grady was an eighteen-year-old woman afflicted with Down's Syndrome. Her parents sought to have her sterilized by tubal ligation, but the hospital rejected the request, refusing to perform the sterilization without authorization by a court. Lee Ann Grady's parents acknowledged that "their daughter has neither knowledge of nor ability to understand sexual relations or reproduction; that she is unable to decide to have and would be unable to care for a child."216 After holding that the Superior Court had the inherent power to consider petitions for the sterilization of noninstitutionalized incompetents, the court proceeded to authorize her parents "to decide as they deem she would were she capable of informed judgment."217 Procedural safe-

Gardner, 534 A.2d 947 (Me. 1987). The court granted permission to remove a nasogastric tube from a man in a persistent vegetative state but characterized the decision as "Gardner's own personal judgment." Id. at 950. It viewed substituted judgment as a doctrine to be used "where the patients, now incompetent, have never stated their intent." Id. Gardner is an odd decision. In most jurisdictions, courts are more likely to apply substituted judgment in cases where the incompetent person had left traces of his intent.

The California courts were also not entirely enamored of substituted judgment. For example, in Barber v. Superior Court of California, $147 \mathrm{Cal}$. App. 3d 1006, $195 \mathrm{Cal}$. Rptr. 484 (1983), the court relied on the classic substituted judgment decisions but did not expressly apply the doctrine in reversing the murder convictions of two physicians who had removed the life-support systems from a patient in a vegetative state. This court seemed implicitly willing to apply substituted judgment, but only if the evidentiary constraints could be imposed and satisfied. Judicial approval was not required. Id; see also Conservatorship of Drabick, $200 \mathrm{Cal}$. App. 3d 185, 208, $245 \mathrm{Cal}$. Rptr. 840, 854 (1988) (finding authority in guardian to withhold medical treatment and criticizing substituted judgment as "legal fiction").

It may be that the state courts will devise other means to achieve and justify the termination of lifesustaining treatment, and substituted judgment will fall by the wayside. One way to achieve the same results might be with legislation. See, e.g., McConnell v. Beverly Enter., 209 Conn. 692, 553 A.2d 596 (1989) (authorizing removal of feeding tube under life-support removal statute, CONN. GEN. STAT. ANN. §§ 19a-570 to -575 (West Supp. 1989)). It will be interesting to see if other states will enact similar legislation and then resort to judicial statutory interpretation to achieve the results for which substituted judgment was borrowed. It may be that the use of substituted judgment to terminate life-support systems will be a fleeting phenomenon in the glacial development of the common law.

There is one federal district court decision in which the doctrine was applied. See Gray ex rel. Gray v. Romeo, 697 F. Supp. 580 (D.R.I. 1988) (holding that right to privacy includes right to refuse life-sustaining medical treatment; applying substituted judgment to authorize removal of feeding tube from patient in vegetative state).

215. In re Grady, 170 N.J. Super. 98, 405 A.2d 851 (1979). There were several important sterilization cases decided after Strunk and before Quinlan in which courts routinely applied the best interests of the incompetent test. See, e.g., Wyatt v. Aderholt, 368 F. Supp. 1382 (M.D. Ala. 1973); A.L. v. G.R.H., 163 Ind. App. 636, 325 N.E.2d 501 (1975); In re Sallmaier, 85 Misc. 2d. 295, 378 N.Y.S.2d 989 (1976). Substituted judgment was criticized in Ruby v. Massey, 452 F. Supp. 361 (D. Conn. 1978). The court held that Connecticut's refusal to sterilize noninstitutionalized mentally retarded girls while providing for the sterilization of institutionalized mentally retarded girls was a denial of equal protection. It applied the best interests of the incompetent test, criticizing substituted judgment because it "lays more stress on what the individual would have done; but a test which calls for the projection of an adult viewpoint into the mind of an individual to function alongside one which has long been incompetent of functioning rationally, is not entirely convincing." Id. at 370-71 n.24. Substituted judgment was not actually applied in a sterilization case, however, until the lower New Jersey court did so in Grady.

216. In re Grady, 170 N.J. Super. at 101,405 A.2d at 852 .

217. Id. at $126,405 \mathrm{~A} .2 \mathrm{~d}$ at 866 . 
guards were spelled out, as well as the requirement of court authorization.18 It was in the name of dignity that Lee Ann Grady's sterilization was authorized "in a manner designed to permit her to realize her greatest potential." 19

Not surprisingly, the Supreme Court of New Jersey agreed with the lower court about Lee Ann Grady's sterilization. ${ }^{220}$ The doctrine of substituted judgment was applied, but, in contrast to the Quinlan decision, the court held that "[i]t must be the court's judgment, and not just the parents' good faith decision, that substitutes for the incompetent's consent." ${ }^{221}$ The reluctance of the court to relinquish control over the sterilization decision was based on its desire to ensure against the risk of abuse. Similarly, the court refused to abandon the language of the more traditional best interests test: the substituted judgment was to be exercised "on behalf of the incompetent in a manner that reflects his or her best interests."222

Some jurisdictions followed New Jersey's lead in using the doctrine of substituted judgment to authorize sterilizations of incompetent young women; ${ }^{223}$ others did not. ${ }^{224}$ Perhaps because of judicial sensitivity to the earlier

218. Before the court could grant a petition seeking authorization to sterilize a noninstitutionalized incompetent, the following conditions were set forth in Grady:

1. That the subject is incapable of understanding the nature of the sexual function, reproduction or sterilization and cannot comprehend the nature of these proceedings, hence is incompetent;

2. That such incompetency is in all likelihood permanent;

3. That the incompetent is presumably not infertile and not incapable of procreation;

4. That all procedural safeguards have been satisfied, including appointment of a guardian ad litem to act as counsel for the incompetent during court proceedings, with full opportunity to present proofs and cross-examine witnesses;

5. That the applicants have demonstrated their genuine good faith and that their primary concern is for the best interests of the incompetent rather than their own or the public's convenience.

Id. at 125-26, $405 \mathrm{~A} .2 \mathrm{~d}$ at 865 (footnote omitted).

219. Id. at 127,405 A.2d at 866.

220. In re Grady, 85 N.J. 235, 426 A.2d 467 (1981).

221. Id. at $251,426 \mathrm{~A} .2 \mathrm{~d}$ at 475 (footnote omitted).

222. Id. at 252,426 A.2d at 475 .

223. See In re Moe, 385 Mass. 555, 432 N.E.2d 712 (1982) (applying substituted judgment to authorize tubal ligation of mentally retarded woman, over dissent's criticism of application as "degrading" and "cruel charade"); Conservatorship of Valerie N., 40 Cal. 3d 143, 219 Cal. Rptr. 387, 707 P.2d 760 (1985). The California Supreme Court, applying substituted judgment, denied authorization for the sterilization of a mentally retarded woman, because it was not shown to be necessary for her habilitation. Justice Lucas, concurring in part and dissenting in part, expressed concern over the shameful history of the sterilization of incompetents. He also found the doctrine of substituted judgment "fundamentally problematic"; about the "right to 'substituted consent," " he worried "whether the 'rights' which we are 'protecting' are in fact more likely to become those of the incompetent's caretaker." Id. at 171, 219 Cal. Rptr. at 408, 707 P.2d at 779 (opinion of Lucas, J.). Chief Justice Bird wrote in dissent:

Like the theory of procreative choice, substituted consent derives its legitimacy from the premise that the affected individual once possessed a capacity to make informed choices or will be able to do so at some point in the future. Even so, the doctrine requires a court to engage in a questionable legal fiction. This departure from reality reaches its zenith when the third party deciding on a matter as vital as whether to undergo sterilization purports to stand in the shoes of a severely retarded adult who has since birth been incapable of making such choices.

Id. at 184, 219 Cal. Rptr. at 415, 707 P.2d at 788 (Bird, C.J., dissenting).

Cf. In re Doe, 533 A.2d 523 (R.I. 1987) (affirming order authorizing abortion on mentally retarded victim of sexual assault, based on court's determination that she would have chosen abortion had she been capable). 


\begin{abstract}
abuses of the eugenics movement, ${ }^{225}$ an invocation of the best interests of the incompetent test often accompanied the language of Lord Eldon's legal fiction. ${ }^{226}$
\end{abstract}

224. While the Supreme Court of Washington cited the lower court decision in Grady, it did not adopt the doctrine of substituted judgment. See In re Guardianship of Hayes, 93 Wash. 2d 228, 230, 608 P.2d 635,637 (1980) (absent controlling legislation, court could authorize sterilization "in the rare and unusual case that sterilization is in the best interest of the retarded person").

In In re Guardianship of Eberhardy, 102 Wis. 2d 539, 307 N.W.2d 881 (1981), the Supreme Court of Wisconsin rejected substituted judgment as a means of authorizing sterilization of incompetent young women. In its criticism of Grady, the court said:

[W]e find it somewhat too facile when discussing the right of privacy, which by definition necessarily refers to the person involved, to find that there is a genuine choice when that choice cannot be personally exercisable. It is indeed true that in Grady there was a decision, but it was not the decision of Lee Ann Grady pursuant to her right of privacy. We believe it somewhat inconsistent for the New Jersey court to equate in a single breath "the choice made in her behalf" and "providing her with a choice."

Id. at 565-66, 307 N.W.2d at 893 (citation omitted). However, the court went on to hold that the circuit courts had constitutional and statutory jurisdiction to authorize sterilization of an incompetent ward. The best interests of the incompetent test would be applied, and in recognition that the legislature was the preferred forum, the Supreme Court of Wisconsin directed that "such jurisdiction shall not be exercised until the state's policy to do so is set forth by appropriate legislation or until further order of this court." Id. at $578-79,307$ N.W.2d at 899.

Two justices in dissent praised the Grady decision, concluding that it was not so important what ratio decidendi was applied, substituted judgment or the best interests of the incompetent test; what mattered was the result. If the legislature would not take responsibility for enacting controlling legislation, then the court's refusal to authorize the tubal ligation left her parents "without justice and without hope." Id. at 593, 307 N.W.2d at 906 (Day, J., dissenting). In his parting shot, Justice Day wrote, "Maybe someday, even in Wisconsin, those with power to do justice will not ask for the wash basin." Id. at 604, 307 N.W.2d at 911; see also id. at 607, 307 N.W.2d at 912 (Callow, J., dissenting).

225. The attitude toward eugenic sterilization in the earlier part of the twentieth century is embodied in the infamous opinion by Justice Holmes in Buck v. Bell, 274 U.S. 200 (1927), in which the Supreme Court upheld a Virginia statute permitting the sterilization of persons believed to suffer from hereditary conditions when society and the patient would derive benefit. Holmes noted that the Commonwealth was supporting patients who could be discharged and become self-supporting if sterile, and that insanity and imbecility were inheritable. He went on to uphold the law with the following reasoning:

We have seen more than once that the public welfare may call upon the best citizens for their lives. It would be strange if it could not call upon those who already sap the strength of the State for these lesser sacrifices, often not felt to be such by those concerned, in order to prevent our being swamped with incompetence. It is better for all the world, if instead of waiting to execute degenerate offspring for crime, or to let them starve for their imbecility, society can prevent those who are manifestly unfit from continuing their kind. The principle that sustains compulsory vaccination is broad enough to cover cutting the Fallopian tubes. Three generations of imbeciles are enough.

Id. at 207 (citation omitted).

Ironically, Carrie Buck, the incompetent in Buck v. Bell, was said to have had a daughter, a "third generation imbecile," who was reportedly "very bright." That daughter died in 1932 of measles after having completed the second grade. See Murdock, Sterilization of the Retarded: A Problem or a Solution?, 62 CALIF. L. REv. 917, $921 \mathrm{n} .22$ (1974). For an overview of the history of the eugenics movement, see Note, Procreation: A Choice for the Mentally Retarded, 23 WASHBURN L.J. 359 (1984); see also Ferster, Eliminating the Unfit-Is Sterilization the Answer?, 27 OHо ST. L.J. 591 (1966); Kindregan, Sixty Years of Compulsory Eugenic Sterilization: "Three Generations of Imbeciles" and the Constitution of the United States, 43 CHI.-KENT L. REV. 123 (1966).

226. See In re A.W., 637 P.2d 366, 375 (Colo. 1981) (labeling best interests of the incompetent test "constitutional" and ruling that court must be final arbiter in sterilization cases); In re P.S., 452 N.E.2d 969, 974 (Ind. 1983) ("Substituted judgment, based on P.S.'s best interests, is permissible because P.S. is incapable by reason of incompetency of making an informed consent."). Other courts alluded to various cases that relied upon substituted judgment but then opted to apply the best interests of the incompetent 
The doctrine of substituted judgment had spread through the termination of life support and sterilization decisions like a forest fire. At the same time, sparks flew into the decisions about refusal of psychotropic drugs and ignited. Lucille Boyd was a sixty-seven-year-old patient in St. Elizabeth's Hospital. ${ }^{227}$ She was suffering from either schizophrenic or organic brain syndrome, and the hospital doctors proposed treating her with psychotropic drugs to "tranquilize her and help reduce the level of auditory hallucinations that troubled her." ${ }^{228}$ Because she had been a Christian Scientist for over two years, she refused the medication. At the trial court level, Mrs. Boyd lost. The judge committed her to the hospital indefinitely and ordered that she undergo "whatever treatment St. Elizabeth's deems appropriate."229

Mrs. Boyd was the first mentally ill person to urge the extension of the doctrine of substituted judgment to assert her right to refuse psychotropic medication. She argued that "the court should attempt to ascertain, as nearly as possible, the choice which that individual would make if competent,"making a predictable nod in the direction of Strunk and Saikewicz. ${ }^{230}$ Lord Eldon's legal fiction had surfaced again in the law of informed consent.

Mrs. Boyd was successful in persuading the District of Columbia Court of Appeals to apply the doctrine of substituted judgment in her case. ${ }^{231}$ The court recognized that "any imputation of a preference to an incompetent person will, to some extent, be fictional," but went on to prefer the approach over the "hypothetical, reasonable person" model. ${ }^{232}$ At least the doctrine of substituted judgment "attempts, however imperfectly, to account for the particular

test. See, e.g., Wentzel v. Montgomery Gen. Hosp., 293 Md. 685, 447 A.2d 1244 (1982); In re Truesdell, 63 N.C. App. 258, 304 S.E.2d 793 (1983), cert. denied, 310 N.C. 745, 315 S.E.2d 710 (1984). The Supreme Court of Iowa decided to avoid the issue of which test to apply; it confined itself to the issue of the trial court's subject matter jurisdiction. See In re Guardianship of Matejski, 419 N.W.2d 576 (Towa 1988).

227. In re Boyd, 403 A.2d 744 (D.C. 1979).

228. Id. at 747. Psychotropic drugs are considered the most effective form of treatment in reducing thought disorder in schizophrenics. They have a number of unattractive side effects, however, including: blurred vision, dry mouth and throat, constipation, diarrhea, low blood pressure, dizziness, faintness, drowsiness, slowing of the thought processes, apathy, weight gain, loss of sexual desire, depression, akathesia (inability to stay still, restlessness, agitation), and Parkinsonisms (mask-like face, drooling, muscle stiffness, rigidity, shuffling gait, tremors). In rare cases, skin rashes and sudden death may result. A possible permanent side effect is tardive dyskinesia, characterized by involuntary movements of the tongue, face, mouth, lips, or jaw. Additionally, ulcerations of the mouth may occur, speech may become incomprehensible, and, in extreme situations, swallowing and breathing may become difficult.

Id. at $752 \mathrm{n.} 13$.

229. Id. at 748 .

230. Id. at 749 .

231. Id. at 750 .

232. Id. at 751. In adopting the doctrine of substituted judgment, the court in Boyd said: We believe this approach is sound, whether religious preference or other factors are involved, for it is the only way to pay full respect to the individuality and dignity of a person who has expressed clear, deeply felt, even sacred preferences while competent, but no longer has the Id. at 750 . capacity to decide. 
qualities of mind and preference known about the individual before the court."233

The Supreme Judicial Court of Massachusetts soon followed suit. Almost all the psychiatrists who examined twenty-one-year-old Richard Roe agreed that he was suffering from paranoid schizophrenia. ${ }^{234}$ During his second hospitalization in a state institution, Richard Roe refused to take any antipsychotic medication. His refusal was based on prior experiences with illicit drugs which had, among other things, caused him to be involved in a car accident. There was also some evidence that Richard Roe had accepted certain tenets of the Christian Science faith.

The Supreme Judicial Court of Massachusetts held that when an incompetent person such as Richard Roe refused antipsychotic medication, his guardian must seek judicial authorization to have the medication administered. ${ }^{235}$ If a court determines that the ward, if competent, would accept the medication, it is to order administration of the drug. If, on the other hand, the court determines that the ward, if competent, would refuse the medication, then the state must provide an interest sufficiently compelling to override his right of selfdetermination. And if that state interest can be satisfied by means other than forced medication, the court is to make an "extended substituted judgment

233. Id. at 751. The court in Boyd also set out some factors to assist in determining whether the incompetent's earlier expressions of intent were deeply felt. A court could inquire into whether the objection, if religious, was a recognized and established one, such as the views of a Jehovah's Witness or Christian Scientist. Also relevant would be the period of time during which the deeply felt views had been held, or the possibility of a demonstrable experience such as a religious conversion, if the views were newly minted. Id. at 752. The court in Boyd also considered the possibility of detrimental side effects important to the decision, as well as the likelihood of cure or improvement with or without the medical treatment. See id. at 751-52. The court also told the trial court how to proceed on remand. First, the court was to determine whether Mrs. Boyd was currently incompetent. If she was, the court was then to inquire into whether the hospital was still seeking authorization for the administration of psychotropic medication. If so, the court was to proceed with the substituted judgment approach, and if it determined that Mrs. Boyd would reject those drugs on religious grounds if she were competent, the court was to refuse to authorize the treatment unless the state could demonstrate a "compelling state interest" that would "justify overriding Mrs. Boyd's putative choice." Id. at 752-53.

234. In re Guardianship of Roe, 383 Mass. 415, 421 N.E.2d 40 (1981). Richard Roe III was 21 years old at the time his guardians were appointed. His junior high school career had been stellar. He had been "a bright and popular student, elected twice as vice president of his junior high school class." Id. at 419, 421 N.E.2d at 43 . In high school, however, he began to use drugs and alcohol and became withdrawn and reclusive. Eventually he left school without graduating. His behavior ranged from bizarre to extremely dangerous. During his second hospitalization in a state hospital, he attacked another patient for no reason. He had also threatened to kill his mother and sister on an earlier occasion. Richard Roe had steadfastly refused all medication. Id. at 420,421 N.E.2d at 44 .

235. Id. at 434,421 N.E.2d at 51. The court in Roe set forth various factors that the probate judge should take into account in making the substituted judgment determination. The factors included: 1) the ward's expressed preferences regarding treatment; 2) his religious beliefs; 3) the impact upon his family; 4) the probability of adverse side effects; 5) the consequences if treatment were refused; and 6) the prognosis with treatment. Id. at 444-48, 421 N.E.2d at 57-59. If the judge discovers that the substituted judgment determination does not comport with the result under the best interests of the incompetent test, the "substituted judgment prevails. In short, if an individual would, if competent, make an unwise or foolish decision, the judge must respect that decision as long as he would accept the same decision if made by a competent individual in the same circumstances." Id. at 449 n.20, 421 N.E.2d at 60 n.20. 
determination ... to choose from among all acceptable and available means of satisfying the state interest." ${ }^{\text {236 }}$ As for Richard Roe, the order to medicate him forcibly was vacated. ${ }^{237}$

Since a flurry of judicial activity in the early 1980 's, ${ }^{238}$ there have been few decisions in which courts have used the doctrine of substituted judgment to assert the rights of mental patients to refuse psychotropic medication. ${ }^{239}$

236. Id. at 433,421 N.E.2d at 51 .

237. Id. at 455,421 N.E. $2 \mathrm{~d}$ at 62 .

238. Just before the Supreme Judicial Court of Massachusetts decided Roe, another case about a patient's right to refuse medication in a state mental hospital was winding its way through the federal court system. See Rogers v. Okin, 478 F. Supp. 1342 (D. Mass. 1979), modified, 634 F.2d 650 (1st Cir. 1980), vacated sub nom. Mills v. Rogers, 457 U.S. 291 (1982). In Rogers, a group of voluntary and involuntary committees challenged the state hospitals' policies of forced medication and involuntary seclusion in nonemergency circumstances, alleging that the policies infringed on their constitutional rights and violated standards of acceptable medical care. The district court held that the allegation of constitutional deprivation was well-founded. The defendants were enjoined from forcibly medicating committed mental patients except in emergency circumstances in which a failure to do so would bring about a substantial likelihood of physical harm to the patients or others. $478 \mathrm{~F}$. Supp. at 1371 . While substituted judgment was neither mentioned nor applied in Rogers, the Boyd decision was cited as support for the right of an incompetent person to refuse antipsychotic drugs. Id. at 1371 n.38.

The Court of Appeals for the First Circuit affirmed the basic constitutional holding but modified the trial court's decision, granting greater discretion to hospital doctors and expanding the definitions of "substantial likelihood of physical harm" and "emergency." 634 F.2d at 656-57. The United States Supreme Court granted certiorari on the issue of forcible medication of involuntarily committed patients. However, in the middle of 1982, the Supreme Court vacated the judgment and remanded the case for a determination of the extent to which the patients' substantive rights were protected under Massachusetts law. This decision to remand was based on Roe, which was decided by the Supreme Judicial Court of Massachusetts in 1981. See Rogers v. Commissioner of the Dep't of Mental Health, 390 Mass. 489, 458 N.E.2d 308 (1983).

In Rogers v. Commissioner, the Supreme Judicial Court of Massachusetts essentially followed its earlier decision in Roe. It concluded that a mental patient has the right to make treatment decisions and does not lose that right until the patient is adjudicated incompetent. Furthermore, the adjudication must precede any determination to override the patient's right to make his own treatment decisions. Id. at 497-98, 458 N.E.2d at 314. If the patient is adjudicated incompetent and refuses medication, " "those charged with his protection must seek a judicial determination of substituted judgment.' "Id. at 500, 458 N.E.2d at 315 (quoting In re Guardianship of Roe, 383 Mass. 415, 435, 421 N.E.2d 40, 51-52 (1981)). The court then proceeded to follow the guidelines that it had set down in Roe, finding the only relevant factual difference to be that the incompetent person in Roe was not institutionalized. The institutionalization of the plaintiffs in Rogers $v$. Commissioner was found to implicate the "likelihood of conflicting interests," a factor to be considered in arriving at the substituted judgment determination. Recognizing that psychiatric institutions must protect third persons, the court made one concession. If the patient posed an imminent threat of harm to himself or others, and if there were no less intrusive alternatives to antipsychotic drugs, the state could invoke its police powers without prior court approval by forcibly injecting the patient over his objection. Otherwise, no other state interest is sufficiently compelling to warrant forcible medication. Furthermore, the state could "in rare circumstances" override a person's refusal of medication even where no threat of violence exists, but only to prevent the possibility of " immediate, substantial, and irreversible deterioration of a serious mental illness." "Id. at 512, 458 N.E.2d at 322 (quoting In re Guardianship of Roe, 383 Mass. at 441, 421 N.E.2d at 55). If the doctors then determine that the medication should continue to be administered and the patient continues to object, the doctors must seek adjudication of his incompetence, and if he is found incompetent, the judge must make a "substituted judgment plan determination." Id.

239. In re Guardianship of Linda, 401 Mass. 783, 519 N.E.2d 1296 (1988), was the most recent case from the Supreme Judicial Court of Massachusetts on the right of an incompetent patient to refuse antipsychotic drugs. The Department of Mental Health filed a petition in the probate court seeking guardianship of a ward who was suffering from schizophrenia, with authority to permit the administration of antipsychotic drugs. At the time of the petition, the ward was voluntarily accepting the medication. When the probate court appointed the guardian, the judge only gave him the authority to permit the administration of the drugs for as long as the ward accepted them. The judge expressly ruled that the Department could 
There was one recent decision, however, in which the District of Columbia Court of Appeals used the doctrine of substituted judgment to authorize the administration of such medication over a patient's objections. ${ }^{240}$ Ollie Bryant was a sixty-eight-year-old woman who was suffering from schizophrenia. She was involuntarily admitted on an emergency basis to St. Elizabeth's Hospital, where she remained pending judicial resolution of her commitment status. During this period of hospitalization, Ms. Bryant's attorney filed a motion with the trial court asking that the hospital be prohibited from medicating her without her consent. At bifurcated proceedings, the trial court found that Ms. Bryant was refusing medication because of her belief that she was a deity and concluded that she was incompetent to make a treatment decision. Her request for interim relief was therefore denied. Several days later, however, the trial court sua sponte granted a temporary protective order, citing the high risk to Ms. Bryant of side effects from the medication and the fact that there was no indication she would be a danger to herself or others before the hearing date.

At the hearing, the trial court heard evidence regarding its exercise of substituted judgment and subsequently issued a memorandum in which it found that Ms. Bryant "if competent would have chosen to receive the psychotropic medication." 241 Despite the fact that Ms. Bryant had often in the past objected to the administration of psychotropic drugs, the trial court discounted those objections because they were "based on a delusional belief that she is God and the erroneous belief that she is not mentally ill." $242 \mathrm{Her}$ motion for a protective order was therefore denied.

The District of Columbia Court of Appeals held that the trial court record supported its determination that Ms. Bryant would have chosen to accept the medication if competent and that the court's decision was consistent with its

not at that time obtain an order to compel administration of the drugs if she later refused to take them. The Supreme Judicial Court of Massachusetts held that the judge "appropriately acted within his discretion in denying this request for a 'prospective' order." Id. at 786, 519 N.E.2d at 1298. Relying on its earlier decisions in Roe and Rogers $v$. Commissioner, the court in Linda reaffirmed its commitment to the substituted judgment doctrine. The substituted judgment should not be premature, since the "'determination will become more precise as it approaches the time at which it will be implemented because, for example, the ward's choice might change as [her] medical condition (and other circumstances) change.' "Id. (quoting Roe, 383 Mass. at 432 n.8, 421 N.E.2d at 50 n.8) (brackets in original).

Some courts alluded to the doctrine or to substituted judgment decisions in wrangling with the issue of administering psychotropic medication over the patient's refusal, but then did not expressly apply substituted judgment. See, e.g., People ex rel. Medina, 662 P.2d 184 (Colo. Ct. App. 1982), aff'd sub nom. People v. Medina, 705 P.2d 961 (Colo. 1985). In the latter case the Colorado Supreme Court upheld the patient's right to refuse antipsychotic medication on more traditional common law grounds. The Court of Appeals of New York also did not avail itself of the doctrine of substituted judgment in a decision upholding the involuntarily committed mental patient's right to refuse antipsychotic medication. See Rivers v. Katz, 67 N.Y.2d 485, 504 N.Y.S.2d 74, 495 N.E.2d 337 (1986) (basing decision on patient's common law and state constitutional rights to determine her own course of treatment).

240. In re Bryant, 542 A.2d 1216 (D.C. 1988).

241. Id. at 1218 .

242. Id. at 1219. 
decision in Boyd. ${ }^{243}$ Because of Ms. Bryant's delusions and failure to accept that she was mentally ill, it was "proper for the court to assign little weight to the first Boyd factor," which emphasized the "nature, intensity, and longevity of the patient's objection to medical care."244 In the absence of statements about the patient's actual preferences, the trial court was permitted to " 'act with respect to the preferences as a reasonable, competent person in the incompetent's situation would have." "245 And a reasonable, competent person in Ms. Bryant's situation would have chosen the medication, despite what Ms. Bryant herself had said.

This then brings the history of the doctrine of substituted judgment up to date. From the removal of vital tissue to the termination of life-support systems, from the sterilization of the mentally retarded to the forced medication of the mentally ill, Lord Eldon's legal fiction has proved a useful mechanism. It is difficult to predict whether the doctrine of substituted judgment will continue to evolve in the law of informed consent, or whether the courts have exhausted the medical contexts in which it might be applied. The strict adherence to the evidentiary constraints in Cruzan might have even tolled the bell for Lord Eldon's legal fiction, if not for Nancy Cruzan. As a device for obtaining informed consent from incompetent patients, the doctrine of substituted judgment may not survive.

It is even more difficult to predict whether some court of the future will discover the doctrine of substituted judgment and use it to solve some problem that we have not yet dreamed of. ${ }^{246}$ Lord Eldon's legal fiction has already undergone one remarkable transformation when it was borrowed from the law of lunacy into the law of informed consent; from the surplus income of Mr. Hinde to the bodies of idiots and lunatics and those unnameable human beings who hover between life and death. Whether the doctrine of substituted

243. In re Boyd, 403 A.2d 744 (D.C. 1979); see supra notes 227-33 and accompanying text.

244. Bryant, 542 A.2d at 1219.

245. Id. at 1220 (quoting Boyd, $403 \mathrm{~A} .2 \mathrm{~d}$ at 750-51 n.11 (quoting Robertson, supra note 127, at 63)).

246. Or even some problem that we have already dreamed of. One petitioner, for example, tried to expand the application of substituted judgment to obtain the authority to dissolve a ward's marriage. See In re Marriage of Drews, $139 \mathrm{Ml}$. App. 3d 763, 487 N.E.2d 1005 (1985). The incompetent was a 31-year-old man who had suffered brain damage from an accident. He was married in 1979 and lived with his wife until 1981 when he entered residential treatment. His mother, as his guardian, petitioned the court requesting dissolution of her son's marriage. She alleged that her daughter-in-law had " failed and refused to perform the duties of a wife under the circumstances and has abandoned [Herbert] to the care of his parents.'" Id. at 766, 487 N.E.2d at 1007 (quoting petition) (brackets in original). One of her arguments was based on the application of the doctrine of substituted judgment to a marital dissolution proceeding. The court did not find the argument persuasive. The scenario presented by the case was analogous "to neither the traditional nor the contemporary conception of the substituted judgment doctrine." Id. at 775, 487 N.E.2d at 1013. Furthermore, there was no evidence that the incompetent would have wanted to dissolve his marriage, and even if he had expressed that desire, the court was "unpersuaded that this in itself would automatically be sufficient to grant Lorraine the authority she requests." Id. at 776, 487 N.E.2d at 1013. The dissent was in favor of a judicial determination by the best interests test. It cited Roe and Strunk, arguing that consenting to surgery, sterilization, or the termination of life-support systems was no more personal than the right to dissolve a marriage. Id. at 778, 487 N.E.2d at 1015 (Jiganti, P.J., dissenting). 
judgment has taken its final form is anyone's guess. But if that guess were mine, I would wager that we are not done with Lord Eldon's legal fiction: that there is metamorphosis of the doctrine of substituted judgment yet to come.

\section{LEGAL Fictions AND tHE DOCTRINE OF SUBSTITUTED JUdGMENT}

Now that I have described the history of the doctrine of substituted judgment as it evolved from the nineteenth-century law of lunacy to the twentiethcentury law of informed consent, so what? Is there anything to be learned from that history about the legal fiction? How should we feel about Lord Eldon's legal fiction, either as a means of giving the lunatic's money away or of obtaining informed consent? Would it be just one of those "cheerful and commodious" empty rooms in Blackstone's Gothic castle? An example of Pound's creative lawmaking? Or a noxious poison, as Bentham might have us believe? Does the history of the doctrine of substituted judgment tell us what might be brutal or dangerous about the legal fiction? Or why would Gray and Fuller insist that a legal fiction be made to wear an emblem of falsity on its sleeve?

It does not take much imagination to answer these questions for Bentham. Even as a means of giving the lunatic's money away, Bentham would have disapproved of Lord Eldon's legal fiction. While Lord Eldon had successfully preserved the principles of property and the duties of the Chancellor, his legal fiction had made a hidden change in the law. Before Whitbread, the Chancellor lacked the authority to make allowances out of the lunatic's surplus income for individuals to whom the lunatic owed no duty of support. After Whitbread, the Chancellor had that authority. This is the kind of hidden change in the law that goes to the very heart of Bentham's disgust with the legal fiction.

Bentham would have preferred to change the law by legislation. The statute granting the Chancellor the power to give the lunatic's money away could have been drafted as a limited exception to the principles of property. The wording could have been hammered out in a public debate, and the participants in that debate would have been charged with the responsibility of representing their constituents. The change in the law would not have been hidden; it would have come about as a result of the political process.

And there is nothing about this particular change in the law that could not have been accomplished through legislation. States have enacted statutes during this century that authorized equity courts to make allowances out of an incompetent's surplus income. ${ }^{247}$ Indeed, weighing the pros and cons of such

247. For example, a California statute, which has since been repealed, provided for the distribution of surplus income of the ward to the next of kin in the discretion of the court after notice and hearing. See CAL. PROB. CODE $\S 1558$ (West 1957) (repealed 1979). Before its repeal, Robertson put the California statute in the class of statutes that allowed "gifts to designated relatives only if the circumstances show that the incompetent if competent would have made the gift." Robertson, supra note 127, at 59 n.64. Assuming 
a statute requires the sort of utilitarian analysis that legislators are most competent to perform. ${ }^{248}$ They would have to consider how such a statute would benefit and burden certain classes of individuals, and whether it would maximize social utility. The balancing would be done in the abstract. There would be no faces to focus upon, no nieces to worry about, no names attached to a petition.

Who would have benefited from a change in the law that achieved the same results as Lord Eldon's legal fiction? The peripheral family members of a few wealthy lunatics. The nature of the benefit would have been cold, hard cash, received before death and distribution. And depending upon how a legislator generally felt about the redistribution of wealth, he might believe that society would benefit from taking money from those who have it, but cannot use it, and giving it to those who do not have it, but need it.

Who would have been burdened by such a change in the law? A few wealthy lunatics. The nature of the burden would have been the loss of cold, hard cash, a diminution of the lunatic's estate. Once again, depending upon how a legislator generally felt about the redistribution of wealth, he might believe that society would be harmed by the erosion of the principles of property. This belief rests on the banks of the proverbial slippery slope. What assurances would property owners have that there would not be a rash of exceptions to the sacred rules? That such a law would not start a trend?

For Bentham, this kind of utilitarian analysis was appropriate only to the legislative process. Judges were not supposed to engage in the formulation of public policy. Their function was to apply the law to particular factual situa-

that Robertson's characterization is correct, the California statute closely approximated Lord Eldon's legal fiction.

New Jersey enacted a similar statute which read as follows:

When a mental incompetent is possessed of or entitled to real or personal estate, the yearly income of which is more than sufficient for the proper support of himself, his household, family, spouse, child or children, and he has 1 or more parents, brothers or sisters of the whole or half blood who are without adequate means of support and dependent on the bounty of others, the superior court or the county court to which the incompetent's guardian is accountable may direct the guardian to pay over to the person or persons aforesaid such portion of the surplus income of the estate of the mental incompetent, not exceeding two-thirds of such surplus annual income, for their support or education in such manner as the court may direct.

N.J. STAT. ANN. § 3A:20-4 (West 1952) (repealed 1979). The current analogue of this statute simply provides that the guardian of an incompetent's estate, with or without court order, "may expend funds of the ward's estate ... for the support of persons legally dependent on the ward and others who are members of the ward's household who are unable to support themselves, and who are in need of support." N.J. STAT. ANN. § 3B:12-46 (West 1983).

248. Sen and Williams characterize utilitarianism as the intersection between two different kinds of theories. The first kind has been called welfarism. Under the theory of welfarism, the correct way to assess a state of affairs is by measuring the aggregate welfare or satisfaction experienced by all the individuals included in the calculation. The second kind of theory has been called consequentialism. Consequentialism is a theory of correct action. It claims that actions should be chosen on the basis of the state of affairs that would come about as a result. Thus utilitarianism as a moral theory recommends that we choose actions on the basis of consequences and that we assess the consequences in terms of welfare. See Introduction, in UTILTTARIANISM AND BEYOND 3-4 (A. Sen \& B. Williams eds. 1981). 
tions. They were supposed to focus on faces, to worry about nieces and others named in a petition. Bentham's insight that judges make changes in the law when they employ devices like legal fictions was probably deemed radical in his day. The prevailing view then was that judges were the discoverers or interpreters of the law, not its inventors. In the late twentieth century, however, Bentham's insight is no longer deemed radical. We are too steeped in the tradition of legal realism to be shocked by an accusation that judges make changes in the law. Of course judges make changes in the law: that is what judges do. Bentham's insight has become a truism, a familiar feature of our intellectual landscape.

While Bentham's insight may have become a truism, we can still ask why judges feel the need to hide the changes by using a legal fiction —or why they are so loathe to put their utilitarian analysis down on paper. With Lord Eldon's legal fiction, there was an exception made to the principles of property, but the judges never owned up to it. In none of the decisions was there an admission that money was flowing from the bank account of the lunatic to the pockets of the petitioners. I think we can safely assume that most of the judges were not generally in favor of the redistribution of wealth. They probably watched their own bank accounts like hawks and did not want the state to have the power to give their money away. The danger they perceived in the legal fiction had nothing to do with the lunatic's loss of his cold, hard cash. It had to do with the implications of granting a court of equity the power to give away anyone's money, with the erosion of the principles of property.

So why not say so? Probably because putting the utilitarian analysis down on paper would have forced the judges to admit that the property of a lunatic was worthy of less protection. And in order to justify this, the judges would have to say things about the lunatic that no one wants to say: things reflecting an attitude that the lunatic is something less than a person-or something less than alive.

To be fair, the lunatic was not ignored; he was always part of the calculation. The decisions were uniform in insisting that he be adequately provided for. Before any allowances were made, the lunatic had to be comfortable: all of his physical needs had to be met, for the present and the future. Beyond expenditures for his maintenance, however, the judges seemed to adopt the attitude that the money remaining in the lunatic's bank account was going to waste. The label "surplus income" reflects this attitude. None of the judges would have attached such a label to his own income earned above subsistence level. Perhaps a judge might have called it "more money than I need to stay alive," but he never would have called it "surplus" income.

It is almost as if the judges were treating the lunatic as dead, at least with respect to his bank account. The later decisions stopped mentioning the possibility that the lunatic might regain capacity or experience a lucid interval. There was no longer a presumption that the lunatic would return to ratify the decision; 
he came to be routinely referred to as "incurably insane." In the same vein, the judges considered it relevant that the petitioners were apparent heirs and legatees. ${ }^{249}$ True, the lunatic was not yet dead, but he might as well have been. His relatives needed the money, and he did not. Why would anyone care if the Chancellor just speeded up the process of distribution? The whole arrangement seemed to make such sense, the judges were willing to look the other way.

Everyone else was willing to look the other way as well. The tolerance for Lord Eldon's legal fiction over the centuries was probably due to nearly universal and silent recognition of its utility. But that was not all. The imposition of the evidentiary constraints also made Lord Eldon's legal fiction tolerable. Looking at the structure of the legal fiction in Whitbread, we see that it was made up of two separate pretenses. The first held that Mr. Hinde, the lunatic, had the capacity to possess intentional states. Lord Eldon seemed to be saying, "This is what $X$ would desire if only $X$ were here." Such a statement implies that $X$ is a being capable of making statements in the form: "I believe that ...." or "I desire that ...." We just assume that $X$ has the requisite cognitive apparatus to formulate beliefs and desires. The only impediment to $X$ 's expression of his intentional states is the fact that $X$ is not present. It is his absence that gives rise to the need for what is essentially an agency relationship. But in Mr. Hinde's case, he has not just stepped out of the room. He is present and accounted for. Rather, we have to make a decision for Mr. Hinde because he is a lunatic and has lost the capacity to possess intentional states. ${ }^{250} \mathrm{~A}$ more accurate statement of Lord Eldon's maneuver in Whitbread would be, "This is what $X$ would desire if $X$ were still a being capable of having beliefs and desires." The agency relationship then collapses: the agent is called upon to carry out the will of a principal who no longer has a will. ${ }^{251}$

249. For example, in In re Carson, 39 Misc. $2 d$ 544, 241 N.Y.S.2d. 288 (Sup. Ct. 1962), the court issued an order authorizing a gift from the incompetent's estate to her adult daughter and son. There were significant tax advantages to making the gift, as well as a savings on the cost of estate administration. The court used Lord Eldon's legal fiction and donned "the mental mantle of the incompetent," concluding " what the court finds would, in all probability, have been the choice of the incompetent if [she] had been of sound mind.'" Id. at 545, 241 N.Y.S.2d at 289 (quoting In re Hills' Will, 264 N.Y. 349, 353-54, 191 N.E. 12, 13 (1934)). When the incompetent died six days after the court's order, the daughter redelivered the money "remaining in her hands as a result of the order in question," since the will postponed the payment of the principal until she reached the age of 40 . Id. at 546, 241 N.Y.S.2d at 290.

250. We actually do not know the nature of Mr. Hinde's lunacy, whether he was senile or delusional. If he were senile, and had lost the ability to form and express his beliefs and desires, then it would be accurate to say that he had lost his capacity to possess intentional states. However, if he were delusional, he might still have the ability to form and express beliefs and desires. We would not recognize those intentional states, however, because of our belief that they were based on an inaccurate assessment of reality. Therefore, when I say that he has lost the capacity to possess intentional states, I am referring to the intentional states of a rational agent.

251. In an agency relationship, the agent remains under the continuous control of his principal regarding matters relating to the object of his agency. As a result of the agency relationship, the agent has the power to effect changes in the legal relations between third parties and his principal. In essence, the agent is legally permitted to alter the principal's relations in the same manner as if the principal had acted himself. See W. SELL, AGENCY 3 (1975). If the principal dies, this results in an automatic termination of the agent's 


\section{It is an arrangement worthy of Lewis Carroll..$^{252}$}

The second pretense in Lord Eldon's legal fiction was built upon the first. It held that the Chancellor had access to the content of the lunatic's fictional intentional states. To employ a spelunking metaphor, Lord Eldon's legal fiction pretended not only that there were drawings on the walls of the underground cave, but also that the explorer had the means of illuminating them. Lord Eldon presented no evidence in Whitbread to support his claim of epistemological superiority with respect to Mr. Hinde's subterranean desires, and this made subsequent Chancellors uncomfortable. Judges, indeed all of us, have a lot invested in the principle that users of language mean what they say. Without adherence to that principle, language does not work. There are exceptions, of course. Social convention and tact give us license to engage in white lying, ${ }^{253}$ and there are other institutionalized forms of falsity as well. ${ }^{254}$ But any deviation from the principle of meaning what one says must be carefully circumscribed. Without limitations set on the use of false statements, we run the risk of linguistic anarchy. There is only so much falsity we can bear.

And Lord Eldon went too far in Whitbread. It was bad enough to have to pretend that Mr. Hinde had the capacity to possess intentional states. The memory of Mr. Hinde as a being capable of having beliefs and desires, howev-

authority, even if he has no notice of the death. The permanent loss of the principal's capacity is treated in the same manner as his death: it acts as an absolute revocation of the agent's authority. See id. at 195.

Joel Feinberg makes some interesting comments about the possibility of an agency relationship existing between animals and human beings in J. FEINBERG, The Rights of Animals and Unborn Generations, in RIGHTS, JUSTICE, AND THE BOUNDS OF LIBERTY 159 (1980). Feinberg points out that between competent human beings an agency relationship can take different forms, depending upon the degree of discretion that the principal grants to the agent. On one end of the spectrum is the agent who does nothing more than carry out the specific instructions of the principal. On the other end is an agent whose principal has given him complete independence to act on his behalf. Usually this second type of agency relationship occurs when the agent has some special expertise, and a certain category of decisions are left to his professional judgment. Feinberg argues that there is no reason why an animal could not be a "totally passive principal" in this second kind of agency relationship, claiming that there are several human instances of agency representation where the principal lacks capacity to contract, such as with children and mentally deficient or deranged adults. Feinberg probably would not agree that Lord Eldon's legal fiction set up an agency relationship worthy of Lewis Carroll, since he did not find his examples of agency representation "logically incoherent or conceptually incongruous." See id. at 164-65.

252. On Alice's journey through the looking glass, she meets the White Queen who is "running wildly through the wood." In discussing their respective ages, the White Queen claims that she is 101 years old, "five months and a day," to which Alice responds:

"I ca'n't believe that!" said Alice.

"Ca'n't you?" the Queen said in a pitying tone. "Try again: draw a long breath, and shut your eyes."

Alice laughed. "There's no use trying," she said: "one ca'n't believe impossible things."

"I daresay you haven't had much practice," said the Queen. "When I was your age, I always

did it for a half-an-hour a day. Why, sometimes I've believed as many as six impossible things

before breakfast."

L. Carroll, Through the LoOKIng Glass 91 (1941).

253. The Oxford English Dictionary defines a white lie as "a consciously untrue statement which is not considered criminal; a falsehood rendered venial or praiseworthy by its motive." 8 OXFORD ENGLISH DICTIONARY 900 (2d ed. 1989).

254. For a fascinating exploration of the various forms of duplicity in which human beings engage, see S. BOK, LYING: MORAL CHOICE IN PUBLIC AND PRIVATE LIFE (1978). 
er, made this first pretense tolerable. The second pretense, that Lord Eldon had access to the content of Mr. Hinde's intentional states, was more difficult to accept. Lord Eldon imparted almost no information about Mr. Hinde, other than his social standing, and without any evidence as to his probable donative intent, this second pretense put too much of a strain on our ability to suspend belief. Subsequent judges therefore imposed the evidentiary constraints. Except for the anomaly of Sheneman $v$. Manring, ${ }^{255}$ bald assertions about what a generic, reasonable lunatic would have done were not sufficient. To support an inference of probable donative intent, the judge had to point to some evidence of what this lunatic might have done with his money prior to losing his capacity-to anchor a present fiction with the weight of a past reality.

If this were just an article about Lord Eldon's legal fiction and the lunatic's surplus income, it would now be time to conclude-and time to go out on a limb. I could argue that Bentham was right: Lord Eldon's legal fiction was a noxious poison, a prime example of the usurpation of legislative power. Or that Blackstone was right: Lord Eldon's legal fiction was a quaint anachronism, a troublesome, but not dangerous evil. Or that the Pound of later years was right: Lord Eldon's legal fiction was an example of creative lawmaking, a brilliant legal mind rising to the occasion. Or that Gray and Fuller were right: legal fictions were legitimate devices, though to be treated with suspicion.

But for me, Lord Eldon's legal fiction, at least as a means of giving the lunatic's money away, fails as a paradigm; it does not generate enough inspiration to make an argument either in favor of or against the use of legal fictions. After all, who wants to go out on a limb if the tree is not worth climbing? If forced to, however, I would have to agree with the unexpressed assessment of the utility of Lord Eldon's legal fiction. The money probably was better spent on the needy peripheral family members of the lunatic, and the principles of property and the Chancellor's obligation to protect the lunatic were probably worth preserving. While the same results could have been accomplished by legislation, the utilitarian analysis that was buried beneath Lord Eldon's legal fiction does not offend.

There was more to the history of substituted judgment, however, that makes Lord Eldon's legal fiction worthy of our concern. It was borrowed into the law of informed consent. Before Lord Eldon's legal fiction was borrowed, equity courts only had the authority to order a course of medical treatment that was of direct benefit to the incompetent. After the doctrine of substituted judgment became part of the law of informed consent, many equity courts assumed the authority to remove vital tissue, to withhold or withdraw life-support systems, to sterilize the incompetent, and to force psychotropic drugs on mental patients over their vocal dissent. Arguably some of these courses of medical treatment directly harmed the incompetent and directly or indirectly benefited others. The

255. See supra notes $160-62$ and accompanying text. 
obligations of the equity court to protect the incompetent remained the same, however. And there was no apparent erosion of the incompetent's constitutional and common law rights of self-determination. To the contrary, the court was supposedly exercising the incompetent's rights by making the substituted judgment for him. ${ }^{256}$ Lord Eldon's legal fiction functioned in the typical fashion when it was borrowed into the law of informed consent. It achieved desired results while still maintaining the doctrinal status quo.

We have something to learn about the legal fiction from the history of the doctrine of substituted judgment. A legal fiction may be benign in one context, and dangerous or brutal in another. This is what happened when Lord Eldon's legal fiction was borrowed into the law of informed consent. The doctrine of substituted judgment allows the state to invade the bodily integrity of the incompetent without having to justify the invasion. By using Lord Eldon's legal fiction, the judges do not have to put the utilitarian analysis down on paper; they do not have to say things about the incompetent that no one wants to say: things reflecting an attitude that the incompetent is something less than a person-or something less than alive.

But this time, the hidden utilitarian analysis has become more ominous. We are no longer talking about the premature transfer of the lunatic's surplus income. The subject matter has to do with the body of the incompetent. Putting this utilitarian analysis down on paper cannot be done in morally neutral terms. It would be impossible to hide the fact that others were going to benefit from the use of the incompetent's body, by taking parts of that body, by relieving them of the presence of that body, by ensuring the barrenness of that body, or

256. Laurence Tribe mentions the conceptual problems inherent in attributing rights to patients who are irreversibly comatose or in a persistent vegetative state in his treatise:

Given the fact that these patients are irreversibly comatose or in a chronic vegetative state, attributing "rights" to these patients at all is somewhat problematic. Of course a sleeping person has rights, as does someone who has temporarily lost consciousness. On the other hand, someone who has died cannot be said to have "rights" in the usual sense; although a person may have a right to determine how her body is dealt with after her death, even that is a troublesome concept. Consider, for example, an individual who opposes a decision to cremate her brother in accord with his will, claiming that she would suffer severe anguish if the will were carried out. Whose rights are involved? Might it depend on the religious beliefs of the deceased? To be sure, these patients are not "dead" in most of the increasingly multiple senses of the term, but the task of giving content to the notion that they have rights, in the face of the recognition that they could make no decisions about how to exercise any such rights, remains a difficult one.

L. TRIBE, AMERICAN CONSTITUTIONAL LAW § 15-11, at 1368 n.25 (2d ed. 1988).

For a thoughtful article describing the conceptual infirmities of current legal standards used to govern decisions on life-sustaining treatment for incompetent patients, see Dresser, Life, Death and Incompetent Patients: Conceptual Infirmities and Hidden Values in the Law, 28 ARIZ. L. REV. 373 (1986). Of particular interest is the author's challenge to any doctrine, such as the doctrine of substituted judgment or the use of advanced directives like the living will, that assigns priority to treatment preferences that were made when the patient was competent. She draws upon the work of Derek Parfit in his book Reasons and Persons, in which Parfit argues that if there is little psychological connection and continuity existing between an individual at two points in time, then past preferences should not necessarily be deemed authoritative to govern future decisions. See id. at 380-81; D. PARFT, REASONS AND PERSONS (1984). Presumably, Professor Dresser would have had little tolerance for Lord Eldon's legal fiction, even if the court were to impose the most stringent of evidentiary constraints. 
by restraining that body through chemistry. In Kantian terms, the judges would be treating the incompetent as a thing, not a person-as a means to achieve the ends of others, not as an end in himself. 257

I do not mean to suggest that our judges have a duty to draft decisions that comport with Kantian principles. ${ }^{258}$ Nor do I mean to suggest that the judicial extension of Lord Eldon's legal fiction to the law of informed consent was necessarily immoral. ${ }^{259}$ What I do mean to suggest is that taking organs from

257. The second formulation of Kant's Categorical Imperative dictates that the rational being must act in such a way that he treats humanity, whether in his own person or in the person of another, as an end, and never merely as a means. To be an end means that the rational being is considered an ultimate source of dignity. This principle of humanity is seen by Kant as the supreme limiting condition on every person's freedom of action. See I. KANT, FOUNDATIONS OF THE METAPHYSICS OF MORALS 47-49 (L.W. Beck trans. 1959).

The whole system of Kantian morality rests upon the notion of the rational being, or vernunfiwesen, and his exercise of practical reason. Only a rational being has a will. Only a rational being can legislate for himself a universal law. Only a rational being has the power to act according to his conception of law. Only a rational being can have dignity. The moral law applies only to rational beings. See generally id.

John Stuart Mill's classic statement from On Liberty also focuses on the principle of respect for persons and expresses its correlate that persons are free to make their own decisions according to their own concept of the good life:

[T]he principle requires liberty of tastes and pursuits; of framing the plan of our life to suit our own character, of doing as we like, subject to such consequences as may follow: without impediment from our fellow-creatures, so long as what we do does not harm them, even though they should think our conduct foolish, perverse, or wrong. . . . The only freedom which deserves the name, is that of pursuing our own good in our own way, so long as we do not attempt to deprive others of theirs, or impede their efforts to obtain it. Each is the proper guardian of his own health, whether bodily, or mental and spiritual. Mankind are greater gainers by suffering each other to live as seems good to themselves, than by compelling each to live as seems good to the rest. J.S. MILL, ON LIBERTY 1-14 (D. Spitz ed. 1975). While Mill made it clear that his Harm Principle only applied to "human beings in the maturity of their faculties" and not to those "who are still in a state to require being taken care of by others," id. at 11 , he never addressed the problem of exercising the rights of self-determination for an incompetent person.

John Rawls, unlike Kant and Mill, does address the issue of how decisions are made by others when the rational powers of individuals are undeveloped, as with children, or impaired, "as in the case of those seriously injured or mentally disturbed." J. RAWLS, A THEORY OF JUSTICE 249 (1971). Rawls calls these "paternalistic decisions," when "others are authorized and sometimes required to act on our behalf and to do what we would do for ourselves if we were rational." Id. Paternalistic decisions are to be

guided by the individual's own settled preferences and interests insofar as they are not irrational, or failing a knowledge of these, by the theory of primary goods. As we know less and less about a person, we act for him as we would act for ourselves from the standpoint of the original position.

Id. Thus Rawls more or less adopts Lord Eldon's legal fiction, complete with the imposition of the evidentiary constraints. If there is no evidence of the incompetent's former intentional states, then Rawls would resort to the objective standard of the individual in the original position, that hypothetical creature in Rawls' scheme who stands behind the veil of ignorance, devoid of his history and specific "psychological propensities." See id. at 12, 249.

258. For an interesting discussion of how public and private morality differ, see T. NAGEL, Ruthlessness in Public Life, in MORTAL QUESTIONS 75 (1979). According to Nagel, the actions of individuals in their public roles and offices are characterized by a "moral impersonality." This moral impersonality has two aspects: it implies a heightened concern for results and also a stricter requirement of impartiality. See id. at 82-83. This means that public officials may be morally justified in using methods usually excluded for private individuals. Or in Nagel's words, the impersonality of public action sometimes "licenses ruthlessness." Id. at 82.

259. The morality of terminating the life-support systems of an incompetent patient is particularly troublesome, no matter what doctrinal mechanism is used to obtain consent. Anyone who has watched a loved one lapse into that ghastly twilight between life and death must appreciate the dilemma that guardians 
incompetents, terminating their life-support systems, sterilizing them, and forcing psychotropic medication upon them all raise deeply disturbing moral issues. And those deeply disturbing moral issues should be examined by the light of day, not hidden in the dark. ${ }^{260}$

And so I think Bentham was right. It is possible that power could be used illegitimately, perhaps even immorally, under the protective camouflage of a legal fiction. But that is not all. The history of the doctrine of substituted judgment tells us something else about why a legal fiction might be dangerous. Lord Eldon's legal fiction was dangerous because of its borrowability: the ease with which it could be transplanted from the law of lunacy into the law of informed consent. That ease did not promote responsible borrowing. To the contrary, Lord Eldon's legal fiction was borrowed irresponsibly.

There are two aspects of the borrowing of Lord Eldon's legal fiction that strike me as irresponsible. The first has to do with the application of the doctrine of substituted judgment to idiots. Anyone who understood the structure of Lord Eldon's legal fiction, and how its application came to be limited by the imposition of the evidentiary constraints, should have seen that it would not work for an idiot; for that matter, it would not work for a lunatic who left no evidentiary trail of his intent. The first pretense of Lord Eldon's legal fiction, that the idiot has the capacity to possess intentional states, flies in the face of reason. Of course, that might be true for a lunatic as well, but we put up with that pretense if there is sufficient evidence of his former intentional states. But someone like Joseph Saikewicz never had any former intentional states. He

face. We are by nature inclined to equate life with good and death with evil, and it is never comfortable when we encounter circumstances that make us declare death a desideratum. When disease or trauma robs a human being of all normal human goods, however, we may indeed come to the decision that death may be considered a benefit rather than a harm. See Foot, Euthanasia, 7 PHL. \& PUB. AFF. 85 (1978), reprinted in MEDICINE AND MORAL PHLOSOPHY (M. Cohen, T. Nagel \& T. Scanlon eds. 1981).

260. True to the tenets of legal positivism, 20th-century judges rarely even mention the word "morality" in their decisions. However, references to our recent shameful past occasionally erupt through the veneer of judicial decisionmaking. It is evidence of the deeply disturbing nature of the moral issues raised by the extension of Lord Eldon's legal fiction that this shameful past was alluded to by the dissent in the Strunk case. Judge Steinfeld referred to his own "indelible recollection of a government which, to the everlasting shame of its citizens, embarked on a program of genocide and experimentation with human bodies." Strunk v. Strunk, 445 S.W.2d 145, 149 (Ky. 1969) (Steinfeld, J., dissenting). Judge Steinfeld did not use the metaphor of the slippery slope, but instead resorted to the floodgates:

I am unwilling to hold that the gates should be open to permit the removal of an organ from an incompetent for transplant, at least until such time as it is conclusively demonstrated that it will be of significant benefit to the incompetent. The evidence here does not rise to that pinnacle. To hold that committees, guardians or courts have such awesome power even in the persuasive case before us, could establish legal precedent, the dire result of which we cannot fathom.

Id. at 151 .

During the fall of 1939, under what was euphemistically called Hitler's "Euthanasia Program," 275,000 people were gassed in killing centers. Most of those killed were deemed incompetent: the mentally retarded, mentally ill, epileptics, senile elderly, sufferers of neurological disorders such as Parkinsonism or multiple sclerosis, other sick or handicapped individuals who had the misfortune of living in a body that was not perfect-a body that rendered them useless eaters, a body that justified their sacrifice so that others could live and flourish. These killing centers for incompetents later served as the model for Hitler's death camps. The blueprints for genocide had already been drawn up and executed. See Foot, supra note 259, at 85 . 
came into the world with a deficient mental apparatus, and he was going to leave it in the same way. How could we ever put up with a pretense that an equity court had access to what the idiot was thinking, when the idiot had never thought before? After all, the common law had treated the lunatic and the idiot differently since the twelfth century, and for good reason. The lunatic had a past and potential future as a rational agent; the idiot did not. To treat them suddenly the same should have been too far from the truth to be acceptable, too false to tolerate. ${ }^{261}$

261. Many other writers have commented upon the conceptual difficulties in applying the doctrine of substituted judgment to someone like Joseph Saikewicz. For example, Allen Buchanan has written:

The very notions of self-determination, and hence a right of self-determination, only apply to a being who possesses, or has the potential for developing, certain complex cognitive functions, including the ability to conceive of the future, discern alternative courses of action, and make judgments about his own good. Most importantly, we can only coherently ascribe a right of selfdetermination to a being who is capable of conceiving of himself as an agent-a being distinct from and capable of changing his environment. Instead of clearly acknowledging the inapplicability of substituted judgment in a case like Saikewicz, the court made a heroic but confused attempt to ascertain the conceptually sophisticated preferences of an individual who never possessed the requisite concepts. Thus, the court vainly struggled to protect a right of self-determination which could never be coherently ascribed to Saikewicz.

Buchanan, The Limits of Proxy Decisionmaking For Incompetents, 29 UCLA L. REV. 386, 394-95 (1981) (footnotes omitted) (emphasis in original). sion:

Another critic of the doctrine of substituted judgment, Walter Weber, wrote about the Saikewicz deci-

When the incompetent not only leaves no evidence of his intent, but never even could formulate legally effective wishes, as in Saikewicz, the court must struggle with a complete absence of guiding factors. In such circumstances, efforts to ascertain the incompetent's intent are doomed from the start: courts cannot attribute a legally conclusive intent to an incompetent without deriving that intent from sources external to the incompetent. Substituted judgment requires the court to piece together testimony from relatives and acquaintances to construct a persona who then represents and decides for the incompetent. The entire endeavor appears more an exercise in fictional characterization than an enhancement of rights.

Weber, Substituted Judgment Doctrine: A Critical Analysis, 1 IssuEs L. \& MED. 131, 145-46 (1985) (citations omitted).

Gerald Dworkin has also been critical of the use of the doctrine of substituted judgment for incompetents for whom there could be no evidence of former intentional states. Dworkin focuses on the organ transplant decision, In re Guardianship of Pescinski, 67 Wis. 2d 4, 226 N.W.2d 180 (1975), in which the Supreme Court of Wisconsin refused to authorize a unilateral nephrectomy from an institutionalized "catatonic schizophrenic" for transplantation of the kidney into his ailing sister, see supra note 178. About the dissenting judge who recommended the application of the doctrine of substituted judgment over the best interests of the incompetent test, Dworkin writes:

I would argue that such inferences are wholly without warrant in the absence of any specific evidence about the incompetent's attitude toward his sister, his inclinations to altruism, his attitude toward risk, and so on. The proxy in such a case ought to be required, as the majority held, to act only in terms of the interests, objectively ascertained, of the incompetent.

Dworkin, Consent, Representation, and Proxy Consent, in WHO SPEAKS FOR THE CHILD: THE PROBLEMS OF PROXY CONSENT 206 (1982).

Martha Minow has made a similar criticism about the use of the doctrine of substituted judgment for newborn infants. After pointing out that even for once-competent adult patients, the "effort is fraught with guesswork," Minow goes on to write, "Yet whatever the success of efforts by family and friends to imagine the past wants of a now comatose eighty-year old, substituted judgment makes little sense for a newborn who has no history nor prior expression of wants." Minow, Beyond State Intervention in the Family: For Baby Jane Doe, 18 U. MICH. J.L. REF. 933, 972-73 (1985). The same could be said for the application of the doctrine of substituted judgment for someone as profoundly mentally retarded as Joseph Saikewicz. See also PRESIDENT's COMMISSION FOR THE STUDY OF ETHICAL PROBLEMS IN MEDICINE AND BIOMEDICAL 
If we take the evidentiary constraints seriously, then the doctrine of substituted judgment should not apply in certain situations. It should not be used for the donation of an organ from a mentally retarded person, for example. Or for the sterilization of a mentally retarded person. Or for the termination of lifesupport systems from either a mentally retarded person, or from a formerly competent person who left us no inkling of his intent. On the other hand, it could be used for the termination of life-support systems from a formerly competent person, provided there is a sufficient residue of words and actions from which to infer his probable intent. But many of the decisions do not take the evidentiary constraints seriously. Lord Eldon's legal fiction was lifted from Whitbread without any sensitivity to its subsequent history. In this way, it was borrowed irresponsibly.

The second aspect of the borrowing of Lord Eldon's legal fiction that strikes me as irresponsible has to do with the analogy made between the body of the incompetent and property. It is true that there are many characteristics of the human body that make it seem like a suitable subject of property. It is a tangible thing; the possessor of the body does exercise over it some of the absolute dominion and control of which Blackstone was so fond. Labeling a thing as property also marks the limits of state power with respect to that thing. As Blackstone and Montesquieu would have it, the state should not tamper with a person's property, for no public good is greater than a person's right to hold onto his own. If the goal were to assure that the state does not have the power to interfere with a person's body, this could be achieved by attaching the label of property to it.

By attaching the label of property to the body, however, we also create a relation between the property owner and all others with respect to that body. If we consider the body as property, then certain rights flow from this ownership, among them the right to sell, the right to squander, the right to rent, and the right to give the body away. It is tempting to carry the analogy to its ultimate conclusion, to grant the full panoply of property rights to all possessors of bodies, incompetent or not. And at least with respect to competent persons, we have sometimes yielded to that temptation. The law of gifts, for example, has been heavily relied upon in providing a means of procuring vital tissue for transplantation. ${ }^{262}$ It is easy to see how this could happen. Gifts are defined

AND BeHaVIoral RESEARCH, DECIDING to FOREgo LIFE-SUSTAINING TREATMENT 132-33, 136 (1983); Annas, The Case of Mary Hier: When Substituted Judgment Becomes Sleight of Hand, HASTINGS CENTER REP., Aug., 1984, at 23; Gutheil \& Appelbaum, Substituted Judgment: Best Interests in Disguise, HASTINGS Center ReP., June 1983, at 8.

262. There is some statutory authority for the limited recognition of property rights in the human body. The Uniform Anatomical Gift Act, which has been enacted in some form by every state in the nation, allows for the donation of the human body or body parts by consent of the decedent by death, by testamentary gift, or by the decedent's heirs after death. See UNIF. ANATOMICAL GIFT ACT §§ 2(a), 2(b), 4(a), 8A U.L.A. 34,43 (1983). The UAGA neither expressly permits nor prohibits the sale of human bodies. See Dukeminier, Supplying Organs for Transplantation, 68 MICH. L. REV. 811, 850 (1970). 
as voluntary transfers of property to another without consideration. ${ }^{263}$ Consenting to the removal of an organ is, under normal circumstances, voluntary and the transferor is not paid for giving his consent. The only significant departure from the definition is the subject of the transfer. A gift is a transfer of property, and a transplantation is a transfer of vital tissue, a transfer of a body part. The law also sanctions the sale of certain regenerative fluids, blood being the most obvious. ${ }^{264}$ Other vital tissues have been bought and sold, for example, a rare antibody ${ }^{265}$ or a piece of a student's upper leg. ${ }^{266}$ The possessor of the vital tissue has something that someone else desperately wants. It therefore seems natural to attach the label of property to that thing, and to grant its possessor the right to sell or give it away.

There are arguments both in favor of and against the recognition of property rights in the human body. ${ }^{267} \mathrm{My}$ own intuition is that the analogy of body as property, carried to its ultimate conclusion, will result in the exploitation of the poor, the sick, and the vulnerable. There are, after all, other ways to use the law to assure that the state keeps its hands, and the hands of others, off a person's body. This is what the law of informed consent is designed to do, and that body of legal doctrine is rooted not in an individual's property interest, but

263. R. BROWN, THE LAW OF PERSONAL PROPERTY $§ 37$ (2d ed. 1955).

264. Over $80 \%$ of the blood supply in this country between the years 1965 and 1967 was obtained from paid donors. This number had decreased dramatically by 1976 with paid donor blood making up only 8.6\% of the American Association of Blood Banks' total collections. R. SCOTT, THE BODY AS PROPERTY 191 (1981). Other bodily fluids and tissues, such as urine, skin, sweat, saliva, and semen, have also been the subject of "paid donations." Id. at 190.

For an analysis of why people make gifts of human blood, see $R$. TIMMUSS, THE GIFT RELATIONSHIP 209 (1971). Titmuss' theory is that the ways in which society organizes and structures its social institutions can either encourage or discourage altruism. See id. at 225. The commercialization of blood and other donor relationships "represses the expression of altruism, erodes the sense of community." Id. at 285. People must be granted the "right to give" in order that they might take "part in the creation of a greater good transcending the good of self-love." Id. at 239. Our motivations to make a gift may be complex. Gifts may be prompted by more than altruism; they can also be expressions of affection, duty, penalties, loyalty, or guilt. As Titmuss puts it:

No donor type can, of course, be said to be characterized by complete, disinterested, spontaneous altruism. There must be some sense of obligation, approval and interest; some awareness of need and of the purposes of the blood gift; perhaps some organized group rivalry in generosity; some knowledge that fellow-members of the community who are young or old or sick cannot donate, and some expectation and assurance that a return gift may be needed and received at some future time.

Id. at 89.

265. In United States v. Garber, 607 F.2d 92 (5th Cir. 1979) (en banc), a woman whose blood contained a rare antibody earned $\$ 200$ a week, $\$ 25$ in cash, 1000 shares of stock, and the use of a car in exchange for regular, and painful, extractions of the antibody from her body. At issue in the case was whether these earnings constituted taxable income.

266. In a personal interview, Marshall J. Cohen, a physics graduate student at the University of Pennsylvania, reported that he had sold 10 grams of nonregenerative thigh muscle to the University Hospital for $\$ 150$. Mr. Cohen also reported that his fellow students at Penn "were more than anxious to part with muscle in exchange for cash." Comment, Tax Consequences of Transfers of Bodily Parts, 73 CoLuM. L. REV. 842, 845 n.21 (1973).

267. For a thorough discussion of those arguments, see Comment, Toward the Right of Commerciality: Recognizing Property Rights in the Commercial Value of Human Tissue, 34 UCLA L. REv. 207, 229-42 (1986). 
in his liberty interest of self-determination. ${ }^{268}$ We also have the ancient arsenal of criminal law. The state will prosecute individuals who offensively touch or threaten to touch the body of another. We do not really need the law of property to protect our bodily integrity. At the very least, before applying the law of property to the body of the incompetent, we should carefully consider what such an analogy might mean. ${ }^{269}$

How then did it happen that Lord Eldon's legal fiction was borrowed so irresponsibly? How did it happen that the doctrine of substituted judgment was ever applied to a lunatic who had never expressed his intent, or worse yet, to an idiot? Or that the borrower resorted to the law of property without giving proper consideration to the underlying analogy? Would it have mattered if Lord Eldon's legal fiction had been made to wear an emblem of falsity on its sleeve? Remember that Gray considered the Roman historic fiction less "brutal" for being expressed in terms of "as if"; and that Fuller claimed legal fictions only became "dangerous" if the user was unaware of the falsity of the statement. According to Fuller, one way to avoid this "danger" was to distinguish the false statement grammatically. Would Lord Eldon's legal fiction have been borrowed so irresponsibly if it had borne such a mark of its falsity?

Gray and Fuller were undoubtedly right: there is virtue in reminding the user of a legal fiction that he is not in fact speaking the truth. The original formulation of Lord Eldon's legal fiction was to do "that which it is probable the lunatic himself would have done." That at least is a statement made in terms of probability. Such statements assume the presence of a conditional,

268. Both of the theories in tort law under which physicians have been held liable for failure to obtain the patient's informed consent seek in some way to secure such self-determination. Battery is based on the consensual relationship between the physician and patient; any medical treatment that exceeds the scope of the patient's consent becomes an intentional touching of a tortious nature. The early informed consent cases were based on a battery theory. See, e.g., Schloendorff v. Society of New York Hosp., 211 N.Y. 125, 129-30, 105 N.E. 92, 93 (1914). The second theory is based on negligence. Under this approach, the focus is on the standard of care, on whether the physician made full and complete disclosure to the patient of all the possible risks of the treatment, and on whether the patient was able to make a truly informed decision. See, e.g., Canterbury v. Spence, 464 F.2d 772, 786-88 (D.C. Cir. 1972).

269. Alexander Capron has also expressed serious reservations about the wisdom of borrowing Lord Eldon's legal fiction from the law of lunacy into the law of informed consent. In an essay about the scope of parental authority in making biomedical choices, Capron pointed at the limitations imposed on the use of Lord Eldon's legal fiction due to the evidentiary constraints and the strained analogy of body as property. He also commented on the difficulty of defining "excess" in the context of biomedical choices:

Thus, though initially attractive, the doctrine of substitute judgment is likely to be of only limited value in understanding the basis of third-party permission for biomedical interventions. First, in the hands of most courts the doctrine is taken to require some individualized evidence about what the incompetent would have done; in the case of a young child a judgment on this point would be speculative. Second, the doctrine is concerned with the donation of property to a specific person; by contrast, at least in the context of medical research, the patient-subject's body is placed at risk for unspecified people (the potential beneficiaries of the knowledge gained) or to "science," as an abstract entity. Third, the limitation that only the excess may be given may render the entire analogy inapposite since it is hard to know what the "excess" would be in a biomedical context, unless it means that only nonharmful interventions are permissible.

Capron, The Authority of Others to Decide about Biomedical Intervention with Incompetents, in WHo SPEAKS FOR THE CHILD: THE PROBLEMS OF PROXY CONSENT 122-23 (1982) (emphasis in original). 
regardless of whether the conditional is expressed; they usually take the form: "If conditions $X$ and $Y$ are assumed to be true, it is probable that event $Z$ would happen." So, for example, if the judge were considering an allowance from the lunatic's surplus income, he would reason, "If the lunatic had been closely related to the petitioner, and if he had been fond of the petitioner, and if he had made gifts in the past to the petitioner, it is probable that the lunatic himself would have granted the petition." The evidentiary constraints imposed on the use of Lord Eldon's legal fiction would force the judge to provide a factual basis to support his probability assertion. It would need to be justified. And while verification of the assumptions made in the conditional might make the probability assertion more likely than not, we would still have to regard such statements with circumspection, to recognize that "probable" does not mean certain.

But once the judge stops using the original formulation of Lord Eldon's legal fiction and instead characterizes his determination as a "substituted judgment," he is no longer reminded of the probable nature of his assertion. Without uttering the incantation of doing "that which it is probable the lunatic himself would have done," the judge may forget that he must justify his statement. He may even forget that he is not himself the lunatic. And once he has forgotten that, there is no longer any need for the presence of a conditional. When we make donative decisions for ourselves, we do not have to utter statements like, "If I were closely related to the petitioner, and if I had been fond of him, and if I had made gifts to him in the past, then I would want to make a gift." We just make the gift; there is no need to say why. Once the judge steps into the Alice in Wonderland agency relationship created by the doctrine of substituted judgment, attempting to determine what " $X$ would desire if $X$ were still a being capable of having beliefs and desires," he runs the risk of becoming $X$, of confusing the probable donative intent of another with his own intent. It is no wonder that he might merge his identity with the lunatic. No wonder indeed. ${ }^{270}$

And yet, I doubt that the incantation of the words of probability would have prevented Lord Eldon's legal fiction from being borrowed irresponsibly. Put

270. Robert Burt, in his provocative book, Taking Care of Strangers, discusses the psychological difficulties that judges face when insisting that treatment decisions for incompetent patients like Karen Quinlan or Joseph Saikewicz "could only be reached through an imagined construction of Joseph's or Karen's individual perceptions and wishes." R. BURT, TAKING CARE OF STRANGERS 149 (1979). Burt argues that "no one could read the intentions of these utterly silent persons without losing the conventional grasp on distinctions between self and other, without utterly confounding his pain with theirs." Id. at 150 . These psychological difficulties result in the ascription by others of "vast, even omnipotent, power to the apparently impotent person" and a "denial of any transactional participation which they mask by assertions of exclusive choice-making capacity." Id. at 153 . What happens, according to Burt, is that the decisionmaker who attempts to make a substituted judgment cannot "sustain the clear-cut delineation between self and other. ... . The participants lost their intrapsychic balance, their grasp on conventionally recognizable reality, because of their inability to find contrapuntal pressure from a conventionally presented 'other' acknowledged as such in Karen Quinlan or Joseph Saikewicz." Id. at 152-53. 
bluntly, the borrower was seduced by Lord Eldon's legal fiction, and it is in the nature of seduction that warnings against it rarely do any good. Just imagine what must have gone on in the mind of the Kentucky judge faced with the plight of Tommy Strunk. He needed to remove a kidney from the body of someone who lacked the capacity to consent to a unilateral nephrectomy. Our approach to the transplantation of vital tissue had already come to rely heavily upon the law of gifts. The analogy of body as property had already been made. Indeed, most lawyers would have said that the Kentucky judge needed to remove a kidney from the body of someone who lacked the capacity to make the gift. ${ }^{271}$

Surely the judge in Strunk was thinking about the law of gifts when he entered the library. The move from the particular to the general, from kidney donations to donations of all kinds, must have been intuitive, taking place in the groundwaters of the unconscious mind. I can almost see the judge muttering to himself in the stacks as he gazed at the A.L.R., "Let's see, what do we have here ... incompetents giving something away." Once he had pulled down the volume on incompetents, which of course no longer distinguished between lunatics and idiots, he would have looked in the table of contents for instances of gift giving. It was here that he no doubt stumbled upon the doctrine of substituted judgment and the annotation of decisions on surplus income. The citation to Whitbread would have led him directly to Lord Eldon's legal fiction, to the equity court doing that which it is probable the lunatic himself would have done. It must have been one of those rare, shimmering moments in the library, when the clouds suddenly part and a shaft of silver light falls upon the page-when the researcher finds just what he was looking for.

The judge in Strunk may have found just what he was looking for, but for some reason he decided not to use Lord Eldon's legal fiction. But it did not matter. Once the doctrine of substituted judgment had made an appearance in an appellate decision about an incompetent and the law of informed consent, the stage had already been set. And to the credit of that New Jersey court, the first time Lord Eldon's legal fiction was actually applied to the law of informed consent, the incompetent was more akin to a lunatic than to an idiot. After all, Karen Quinlan had once been a being capable of having beliefs and desires. There was even some evidence, although it was found insufficient by the court, of how she would have decided had she been competent. By not imposing the evidentiary constraints upon the application of Lord Eldon's legal fiction, however, the New Jersey court turned Karen Quinlan into an empty puppet. An empty puppet lined with cool, black velvet. And all the judge had to do to make the puppet talk, to make the puppet laugh or cry, to make the puppet

271. "As in other transactions dependent upon the intent of the person whose acts are being interpreted, in asserted gift transactions, the donor must possess sufficient mental capacity to appreciate the nature of the act performed ...." R. BROWN, THE LAW OF PERSONAL PROPERTY $§ 37.12$ (2d ed. 1955). 
want this or that, was to slide the puppet onto his hand and make it come alive. What a marvelous trick, so simple and effective.

This then is how Lord Eldon's legal fiction came to be applied to someone like Joseph Saikewicz. There the borrower failed to notice the qualitative difference in the puppets, that Mr. Hinde had been a lunatic and Mr. Saikewicz was an idiot. The significance of the difference would have been lost on the borrower anyway; he had not done his homework on the evidentiary constraints. Nor had he stopped to consider the implications of the analogy of body as property. He borrowed irresponsibly.

Perhaps we should not be so harsh on the borrower of Lord Eldon's legal fiction. As soon as he picked up that empty puppet, he became ensorcelled. Even those of us watching the show, as soon as the puppet began to talk, fell sway to the magic of the performance. It became harder and harder to remember that the puppet was not real. ${ }^{272}$ When Joseph Saikewicz came onto the stage and told us that he would rather not undergo chemotherapy, respecting his wishes seemed like the right thing to do. We let Joseph Saikewicz die because that was what the Joseph Saikewicz puppet said he wanted. With no evidentiary constraints imposed upon the application of the legal fiction, the judge was free to make up the script as he went along. The puppet could donate his organs; the puppet could request that he be sterilized; the puppet could consent to taking dangerous drugs; the puppet could volunteer to die. The puppet could say almost anything, and we would believe him. Like the borrower, we too became seduced by Lord Eldon's legal fiction.

I do not know whether the risk of irresponsible borrowing was the danger that Gray and Fuller were alluding to, or whether we run that risk with every legal fiction. But at the very least, we should be cautious of any legal fiction that involves impersonation, of any device that allows one human being to inhabit the shell of another. Our minds are so vulnerable to animation. What starts out as an illusion, as a construct of imagination, takes on a life of its own, becoming more real than reality itself. When we assume the persona of another, we need to be constantly reminded of that assumption. Something hidden, something potentially dangerous or brutal, can go on beneath the surface of a legal fiction. With the doctrine of substituted judgment, the raw truth is: the judge and the puppet do not stand on equal footing; they are not

272. Confusion about where to draw the line between fact and fiction has been a recurrent theme in the genres of mystery and science fiction. Puppets who appear to be real, or who become real, have been the subject of several recent works. My favorite was a Twilight Zone episode entitled "The Dummy." Jerry, an alcoholic ventriloquist, becomes convinced that his "knotty pine partner," Willie, is predisposed toward evil. Jerry abandons Willie and ends up trying to smash him to pieces. Willie somehow takes over the ventriloquist's body. In the last scene, Jerry is seated on Willie's lap; he now plays the dummy.

Rod Serling, who adapted "The Dummy" from a story by Lee Polk, was influenced by a 1945 British film called Dead of $N i g h t$, in which Michael Redgrave plays a mentally disturbed ventriloquist who becomes convinced that his dummy is alive. There was also an episode on Alfred Hitchcock Presents in which a woman falls in love with a handsome ventriloquist, only to discover that the ventriloquist is a dummy, and the "dummy" is a dwarf ventriloquist. See M. ZICREE, THE TWLIGHT ZONE COMPANION 284-85 (1982). 
both rational, autonomous human beings. Beneath the facade of equality, there is total power in the wielder of the words, and no power in his victim. The judge is in control of the incompetent, and with that control comes an obligation-an obligation to protect the incompetent, not to let him wither and die, and virtually fall off the vine. An obligation not to sacrifice the puppet in the name of his own dignity.

\section{CONCLUSION}

We should still be writing and talking passionately about the legal fiction. It should once more become a hot topic on the jurisprudential agenda. Words of law matter; they determine how others will lead their lives, and sometimes how they will die. Judicial artifice can render the exercise of state power invisible. This is what happened with Lord Eldon's legal fiction, and what happened to the body of the incompetent was not benign.

And as we write and talk passionately about what to do with the body of the incompetent, we should be careful not only about what we say, but also about the way in which we say it. I too should be wary of my own metaphor. In evoking the imagery of puppetry, I should remind myself that in the application of the doctrine of substituted judgment, there are no puppets in this scene: ${ }^{273}$

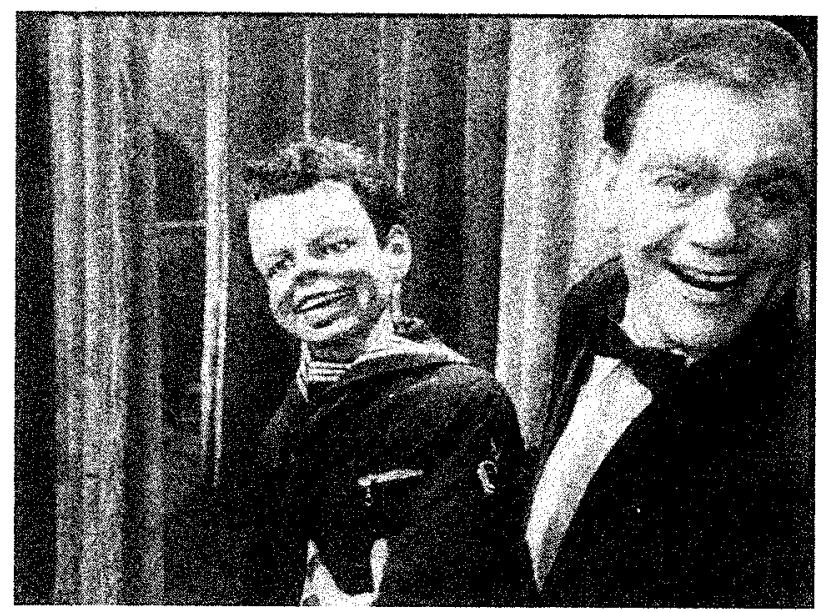

Only two hapless human beings. Neither of them chose his part, and but for the grace of God, either of them could be me.

273. Photograph courtesy of the Serling Archives, Roy H. Park School of Communications, Ithaca College, Ithaca, New York. 
